University of Montana

ScholarWorks at University of Montana

Graduate Student Theses, Dissertations, \&

Professional Papers

2003

\title{
Effects of peripheral cooling on substrate selection during exercise
}

David Elias Lankford

The University of Montana

Follow this and additional works at: https://scholarworks.umt.edu/etd

Let us know how access to this document benefits you.

\section{Recommended Citation}

Lankford, David Elias, "Effects of peripheral cooling on substrate selection during exercise" (2003). Graduate Student Theses, Dissertations, \& Professional Papers. 6376.

https://scholarworks.umt.edu/etd/6376

This Thesis is brought to you for free and open access by the Graduate School at ScholarWorks at University of Montana. It has been accepted for inclusion in Graduate Student Theses, Dissertations, \& Professional Papers by an authorized administrator of ScholarWorks at University of Montana. For more information, please contact

scholarworks@mso.umt.edu. 


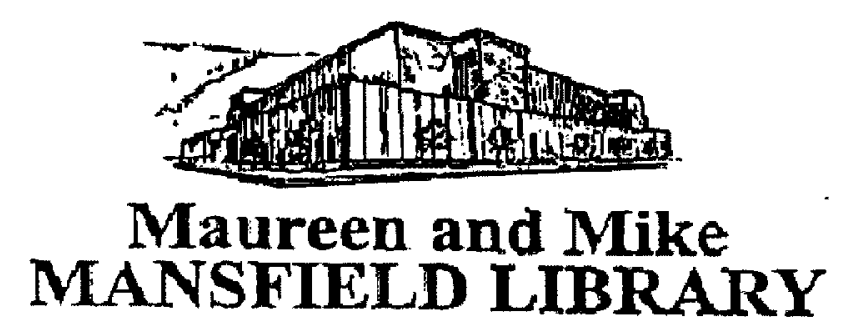

The University of

Montana

Permission is granted by the author to reproduce this material in its entirety, provided that this material is used for scholarly purposes and is properly cited in published works and reports.

**Please check "Yes" or "No" and provide signature**

Yes, I grant permission

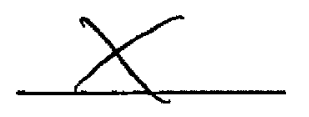

No, I do not grant permission

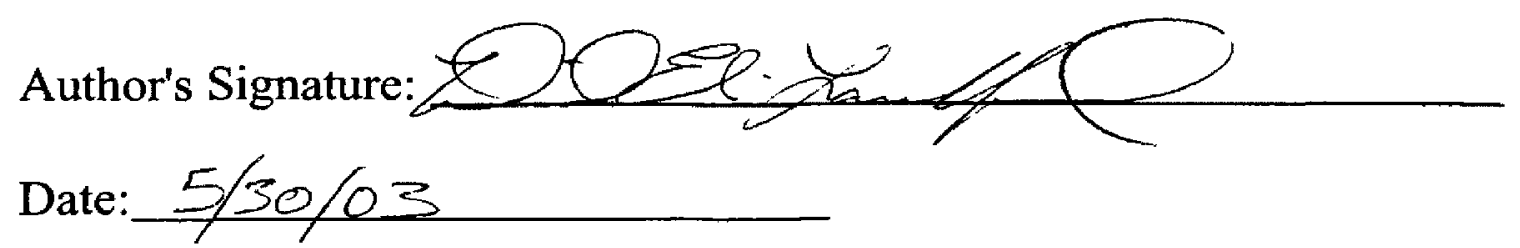

Any copying for commercial purposes or financial gain may be undertaken only with the author's explicit consent.

$8 / 98$ 


\title{
Effects of Peripheral Cooling on Substrate Selection During Exercise
}

\author{
By \\ David Elias Lankford \\ B.S. University of Utah \\ Salt Lake City, UT 2001 \\ Presented in partial fulfillment for the requirements for the degree of: \\ Master of Science \\ The University of Montana \\ Missoula, MT 2003
}

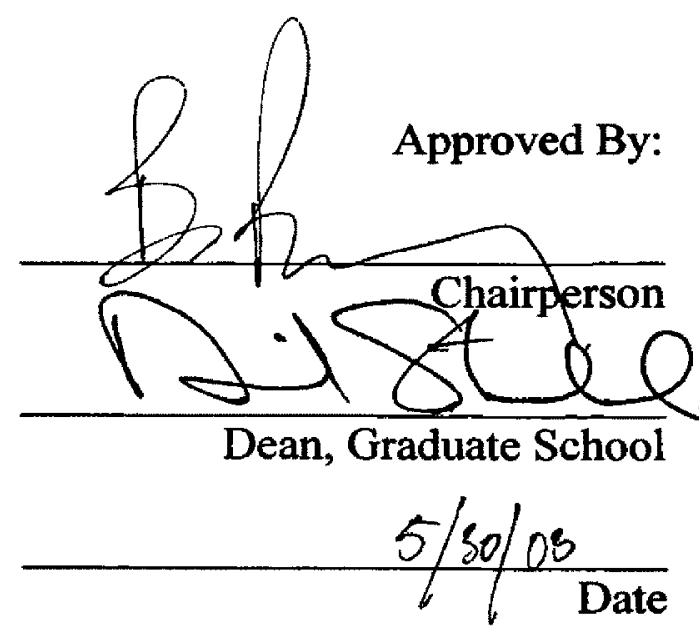


All rights reserved

INFORMATION TO ALL USERS

The quality of this reproduction is dependent upon the quality of the copy submitted.

In the unlikely event that the author did not send a complete manuscript and there are missing pages, these will be noted. Also, if material had to be removed, a note will indicate the deletion.

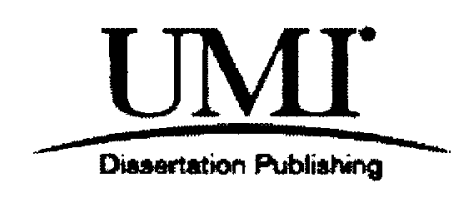

\section{UMI EP37177}

Published by ProQuest LLC (2013). Copyright in the Dissertation held by the Author.

Microform Edition @ ProQuest LLC.

All rights reserved. This work is protected against unauthorized copying under Title 17, United States Code

\section{ProQuest}

ProQuest LLC.

789 East Eisenhower Parkway

P.O. Box 1346

Ann Arbor, Ml $48106-1346$ 
Effects of Peripheral Cooling on Substrate Selection During Exercise

Director: Brent C. Ruby, Ph.D.S

Previous research has demonstrated that exercise in the heat significantly increases the rate of muscle glycogenolysis compared to exercise under normal ambient temperatures. Purpose: To examine the effects of peripheral cooling via the RTX cooling device (Avacore Technologies Inc.) on whole body substrate oxidation during submaximal exercise at a moderate ambient temperature $\left(28^{\circ} \mathrm{C}\right)$. Methods: Subjects included recreationally active college aged males $(\mathrm{N}=16)$. Each subject performed an initial cycle ergometer VT/VO2 max test. Subjects completed two 45-minute cycle ergometer trials at a work rate equivalent to approximately $90 \% \mathrm{VT}$, one with cooling from the RTX cooling device (manifold $\mathrm{T}=22^{\circ} \mathrm{C}, \mathrm{P}=635 \mathrm{mmHg}$ ) and one without. Rectal temperature was continuously recorded throughout both trials. Trials were performed in a random, crossover design. Dependent variables were analyzed using pre-planned comparisons. Statistical significance was established at $p<0.05$. Results: Both groups maintained constant carbohydrate use during the cooling trial, whereas without cooling carbohydrate use was greater at the beginning of exercise $(p<0.05)$ and decreased with time $(p<0.05)$. Fat use increased with time in both trials for both groups. There was no difference in rectal temperature between trials. Conclusion: Despite a similar response in rectal temperature across trials, peripheral cooling with the AVAcore RTX cooling device altered substrate use during submaximal exercise without any difference in total energy expenditure. 


\section{Table of Contents}

Chapter One: Introduction

Introduction

Problem

Research Hypotheses One

Justification One 3

Research Hypothesis Two

Justification Two

Significance

Rationale

Limitations

Delimitations

Definition of Terms

Chapter Two: Review of Literature

Heat and Metabolism by Sequence of Time

Body Composition and Substrate Selection $\quad 14$

Gender and Substrate Selection

Chapter Three: Methodology

$\begin{array}{lr}\text { Settings, Subjects and Descriptives } & 15\end{array}$

$\begin{array}{lr}\text { Exercise Testing } & 16\end{array}$

$\begin{array}{lr}\text { Statistics } & 17\end{array}$

Chapter Four: Results

Descriptive Data: Table 1, Table 2 18

CHO Utilization $\quad 19$

$\begin{array}{lr}\text { Fat Utilization } & 19\end{array}$

RER 20

Heart Rate $\quad 20$

RPE 20

Temperature $\quad 21$

$\begin{array}{ll}\text { Lactate } & 21\end{array}$

$\begin{array}{lr}\text { References } & 22\end{array}$

Appendix I: Attachments

Informed Consent Form $\quad 25$

$\begin{array}{lr}\text { Par-Q } & 29\end{array}$

$\begin{array}{ll}\text { Appendix II: Statistical Results } & 30\end{array}$

$\begin{array}{ll}\text { Appendix III: Manuscript } & 74\end{array}$ 


\section{Chapter One: Introduction}

It is widely recognized that an augmented rise in body temperature during submaximal exercise will increase carbohydrate and more specifically glycogen utilization during exercise ${ }^{3,5,7}$. Previous research has shown that an attenuated rise in body temperature either by reducing ambient temperatures ${ }^{5,6}$, or by cooling ${ }^{13,18}$ will reduce glycogen flux and ultimately total carbohydrate oxidation.

Heat stress also influences lipid mobilization and oxidation. Plasma free fatty acid levels are unaltered by exercise and heat stress ${ }^{7}$. However, it has been shown that intramuscular triacylglycerol utilization ${ }^{7}$ and free fatty uptake ${ }^{11}$ are reduced with thermal stress, possibly suggesting that free fatty acid release by adipocytes may be reduced during the combination of heat stress and exercise ${ }^{2}$. Brooks et al. ${ }^{1}$ research indicates that elevated temperature decreases phosphorylative efficiency in isolated skeletal muscle mitochondria also causing an increased reliance on carbohydrate as the primary substrate. Febbraio ${ }^{3}$ suggests that elevated muscle temperature may impair mitochondrial function. Of note, findings by Mills et al. ${ }^{15}$ observed an increase of lipid peroxides, an indicator of oxidative stress, in the plasma of hyperthermic horses exercising to fatigue, possibly supporting the notion that heat stress may cause metabolic dysfunction.

Studies have examined RER ${ }^{6,12}$, rate of glucose disposal (glucose Rd) ${ }^{12}$, carbohydrate oxidation ${ }^{9}$, and muscle glycogen depletion ${ }^{6,18}$ to point toward the use of carbohydrates during heat stress. It has been shown that heat stress stimulates an increase in hepatic glucose production without an augmented glucose disappearance rate ${ }^{12}$. Febbraio ${ }^{3}$ suggests that an increase in body temperature and perceived effort promote a 
feed-forward effect resulting in increased blood catecholamines which in return increases glycogen utilization in contracting skeletal muscle. Assuming non-protein use, past research has shown that RER is increased with heat stress ${ }^{6,12,20}$. Augmented glycogen utilization during heat stress was first reported by Fink et al. ${ }^{7}$, while comparing exercise in $40^{\circ} \mathrm{C}$ with $9^{\circ} \mathrm{C}$. Fink also noted a shift in RER and reduced intramuscular triglyceride use indicating increased carbohydrate utilization. Using water-perfused cuffs to cool one thigh and heat the other during submaximal exercise, Starkie et al. ${ }^{18}$ found that muscle glycogen levels were lower in the heated leg compared with the cool leg.

Studies have consistently shown that enhanced heat stress increases blood lactate accumulation during exercise ${ }^{6,7,12,20}$. Hargreaves et al. ${ }^{12}$ suggests than an increased blood lactate is associated with increased rate of intramuscular glycogen utilization, since blood glucose uptake is reduced with heat, yet total carbohydrate oxidation is increased.

In regards to body composition and substrate oxidation, previous findings from our lab indicate that high fit (ventilatory threshold $>30 \mathrm{ml} / \mathrm{kg} / \mathrm{min}$ ), low fat $(10.5 \pm 2.3 \%$ ) individuals are better able to maintain lipid metabolism during increased relative intensities compared with low fit (ventilatory threshold $<20 \mathrm{ml} / \mathrm{kg} / \mathrm{min}$ ), high fat mass $(27.1 \pm 5 \%)$ individuals ${ }^{14}$. Although explanations for these findings are unknown, the thermal control in low fat individuals may, in part explain the observed increase in lipid oxidation.

For cooling purposes this study will use an AVAcore (AVAcore Technologies Inc.) hand device designed to manipulate core temperature. Built to enhance heat extraction by amplifying blood flow to the hand via negative pressure within the capsule, the device will influence blood temperature in the hand through contact with a metal plate 
cooled by $22^{\circ} \mathrm{C}$ water flow. To our knowledge, no studies have been performed that examine the effects of thermoregulation on substrate utilization, while cooling with a temperature $<10^{\circ} \mathrm{C}$ different from the ambient exercise temperature.

\section{Problem}

The purpose of this study will be to examine the effects of peripheral cooling at $28^{\circ} \mathrm{C}$ ambient temperature on substrate utilization at $90 \%$ ventilatory threshold using a hand device developed by AVAcore Technologies. The secondary purpose of this study was to examine the substrate selection response between body compositions to the peripheral cooling.

Hypothesis One

Peripheral cooling with the hand device will attenuate the rise in core body temperature sufficient to attenuate the reliance on carbohydrates and glycogen stores.

\section{Justification of Hypothesis One}

Febbraio states that $\mathrm{a}>.5$ degree Celsius difference in body temperature will alter substrate selection ${ }^{3}$. Young et al. ${ }^{20}$ and Febbraio et al. ${ }^{4}$ suggest that increased temperature will cause a shift in enzyme action, primarily phosphofructokinase, glycogen phosphorylase, and pyruvate kinase, due to the Q-10 effect thus shifting substrate use towards increased carbohydrate utilization and a reduced lipid oxidation. The cooling device from AVAcore Technology has a negative pressure inside the capsule so when the 
hand is placed within it continually circulates superficial blood flow through the hand. Water cooled to $22^{\circ} \mathrm{C}$ flows through the capsule floor allowing blood to be cooled without stimulating vasoconstriction. Previous findings from our lab found that cooling using the hand device altered substrate selection in submaximal exercise in a $100^{\circ} \mathrm{F}$ environment.

Hypothesis two

Subjects with greater than eighteen percent fat mass will have a lower fat oxidation at a given time during exercise than those with less than ten percent fat mass.

Justification of Hypothesis Two

Recent findings from our lab ${ }^{14}$ indicate that high fat, low fit individuals had similar fat oxidation at $70 \%$ of ventilatory threshold (VT) to those with low fat, high fitness levels. However at $85 \%$ and $100 \%$ of VT, high fat, low fit individuals had significantly less fat oxidation than those with low fat, high fitness levels.

\section{Significance of the study}

Research has shown that attenuated rise in body temperature either by reducing ambient temperature ${ }^{6}$ or by cooling ${ }^{13,18}$ will reduce glycogenolic rate and carbohydrate oxidation. Sparing glycogen stores and increasing lipid metabolism can benefit performance during exercise. Previous research has used extreme temperature difference ${ }^{6}$, or radical cooling ${ }^{13}$ and heat temperatures ${ }^{18}$ to alter substrate selection; our study will 
use a cooling temperature $6^{\circ} \mathrm{C}$ lower than ambient to examine if even minute differences in temperature will make significant differences in substrate selection. Our study will also compare differences in substrate use between body compositions.

\section{Rational of the study}

Previous attempts to regulate core temperature have been done using methods such as ice packs ${ }^{13}$, lowering ambient temperature ${ }^{4,6}$ or direct cooling of working muscle ${ }^{18}$. Our study will examine the effects of peripheral cooling using an AVAcore hand device. We will also examine the efficacy of the AVAcore device to alter substrate use between body compositions. Future use from results of this study may include thermoregulation attempts in athletics to retain glycogen stores or health industry to enhance lipid oxidation duration.

\section{Limitations}

i/ Physical capacity of the subjects: The subjects will have differing fitness levels and physical capacities. To correct for this, all subjects will work at a relative intensity.

ii/ Non-randomized samples: The subjects will not be randomly selected. The subjects will be acquired on a volunteer basis.

iii/ Instrumentation: There is inherent error with all instrumentation. Using trained testers and calibrated equipment will minimize this error. 
iv/ Body Temperature: Beginning core temperatures cannot be controlled.

\section{Delimitations}

i/ Body Composition: Subjects will have either $<10 \%$ fat mass or $>18 \%$ fat mass.

ii/ Age of subjects: Only college males will be used in this study. Aging has been shown to influence substrate use during exercise ${ }^{16}$. Therefore, in this study only college-aged subjects will be used.

iii/ Gender: Hormone differences between genders have been shown to alter substrate use ${ }^{19}$. In this study only males will be used to eliminate differences between genders.

iv/ Temperature: Room temperature will be maintained at $28^{\circ} \mathrm{C}$.

\section{Definition of Terms}

Relative intensity: Intensity relative to a specific level of stress.

Respiratory Exchange Ratio (RER): The ratio of $\mathrm{VCO}_{2}$ expired to $\mathrm{VO}_{2}$ consumed. RER is used to indicate the primary substrates being used. Since fat metabolism requires more oxygen, a lower RER indicates increased fat oxidation. Theoretically, an RER of 1.0 is indicative of $100 \%$ carbohydrate oxidation and an RER of .71 is indicative of $100 \%$ fat oxidation. 
Substrate: A selected fuel utilized to produce energy.

$\mathrm{VCO}_{2}$ : The amount of carbon dioxide produced/minute; generally expressed as $\mathrm{L} / \mathrm{min}$.

$\mathrm{VO}_{2}$ : The amount of oxygen utilized by the body/min; generally expressed as $\mathrm{L} / \mathrm{min}$.

Thermoregulation: Regulation of deep body temperature.

Ventilatory Threshold: An indirect measure of the lactate threshold that is based on nonlinear increases in metabolic gases. VT will be defined as the first sustained raise in VE/ $\mathrm{VO}_{2}$ without a rise in $\mathrm{VE} / \mathrm{VCO}_{2}$ concurrent with the first rise in excess $\mathrm{CO}_{2}$, and the first break above a slope of 1.0 in the v-slope method.

Rate of Perceived Exertion (RPE): Subjective means for measuring an individual's exertion level determined by the Borg scale from 6-20. A higher number indicates in increased perceived exertion. 


\section{Chapter Two: Literature Review}

\section{Heat and Metabolism by Sequence of Time}

Brooks et al. ${ }^{1}$ studied the phosphorylative efficiency of isolated rat muscle mitochondria in vitro by examining the $\mathrm{ADP} / \mathrm{O}$ ratio over several varying temperatures. Between $25^{\circ} \mathrm{C}$ and $40^{\circ} \mathrm{C}$ they observed constant $\mathrm{ADP} / \mathrm{O}$ ratios. However as muscle temperature increased above $40^{\circ} \mathrm{C}$, the $\mathrm{ADP} / \mathrm{O}$ ratio decreased linearly. These findings suggest that for a given $\mathrm{VO}_{2}$ the rate of ATP degradation was higher than ADP rephosphorylation.

In a study by Fink et al. ${ }^{7}$, subjects performed work in heat $\left(41^{\circ} \mathrm{C}\right)$ and cold $\left(9^{\circ} \mathrm{C}\right)$ to assess the effects of environmental stress on muscle metabolism during exercise. Each trial consisted of work at $70-85 \%$ of $\mathrm{VO}_{2}$ max for 3-bouts of 15 -minutes each with a 10 minute rest in between each bout. Findings showed that heart rate, rectal temperature, muscle glycogen utilization and blood lactate were all significantly higher in the heat. Subjects showed reduced muscle triglyceride depletion during exercise in the heat, yet serum triglycerides levels were slightly lower with exercise in the heat. Plasma free fatty acid levels were not different between the trials. In conclusion, Fink noted that blood and muscle lipids indicate a trend toward less lipid metabolism in the heat than in the cold. An enhanced rate of glycolysis during the heat was reflected by a greater lactate production and glycogen utilization.

Young et al. studied the effects of heat acclimation on muscle metabolism during submaximal exercise ${ }^{20}$. Subjects were asked to cycle for 30 -minutes at $70 \%$ maximal 
$\mathrm{VO}_{2}$ in a cool $\left(21^{\circ} \mathrm{C}\right)$ and hot $\left(49^{\circ} \mathrm{C}\right)$ environment and again after acclimatization. RER and plasma lactate were significantly higher in the heat trials compared with the cold trials. Muscle glycogen utilization did not differ at any point between the heat and cold trials. Acclimation lowered aerobic metabolic rate and plasma lactate in both temperatures. Young concluded that the increased plasma lactate during heat is not resultant upon increased glycogen since no differences in muscle glycogen were found.

Using 11 dogs as subjects, Kozlowski et al. ${ }^{13}$ found that trunk cooling with ice packs improved total running performance. Cooling resulted in a reduced muscle glycogen depletion and blood lactate $(\mathrm{p}<0.05)$. Following the exercise to exhaustion, muscle ATP was higher $(\mathrm{p}<0.01)$, ADP content was lower $(\mathrm{p}<0.05)$ and AMP content was lower $(p<0.01)$ in cooled dogs. Kozlowksi concluded that hyperthermia promoted lactate accumulation and more rapid glycogen depletion possibly accounting for local fatigue and decreased performance.

Febbraio et al. ${ }^{6}$ had subjects cycle for 40 minutes at $70 \%$ peak $\mathrm{VO}_{2}$ in ambient temperatures of $20^{\circ} \mathrm{C}$ and $40^{\circ} \mathrm{C}$ to examine the effects of heat on metabolism. RER, muscle glycogenolysis, lactate and heart rate were significantly higher in the heat $(p<0.05)$. Rectal temperatures were higher and creatine phosphate stores were lower in the heat trial $(p<0.05)$. There were no differences in post exercise ATP/ADP ratio or IMP concentrations possibly indicating that although ATP demand is increased in the heat, the demand is met by an increase in anaerobic glycolysis and creatine phosphate hydrolysis. 
Febbraio et al. ${ }^{4}$ looked at the influence of elevated muscle temperature on metabolism during intense, dynamic exercise. Subjects underwent 2 trials consisting of a 2-minute workload at $115 \%$ maximal $\mathrm{VO}_{2}$, either without preheating (CT) or after having their thigh wrapped in a heating blanket for 60-minutes (HT). Core temperature was not affected by the heating but muscle temperature within the thigh was significantly different $(p<0.01)$. Muscle glycogen and lactate concentrations were not different before exercise, but lactate concentrations were higher in HT and glycogen concentrations were lower in HT $(\mathrm{p}<0.05)$. During exercise ATP degradation was higher in HT than CT $(p<0.05)$. Febbraio suggests that increased adenine nucleotide degradation will result in further allosteric activation of enzymes such as glycogen phosphorylase, PFK, and LDH. He concludes that elevated muscle temperature increases glycogenolysis, glycolysis, and high-energy phosphate degradation during exercise.

In a study done in $20^{\circ} \mathrm{C}$ and $3^{\circ} \mathrm{C}$ ambient temperatures, Febbraio et al. ${ }^{5}$ found that exercise in cool ambient temperature attenuated glycogen depletion. Heart rate, plasma catecholamines and rectal temperature were significantly higher $(\mathrm{p}<0.05)$ during the heat trial. Lactate and blood glucose levels were not significantly different. However, muscle glycogen levels were significantly higher in the cool trial. Febbraio reasons that findings of a higher RER in the cool trial may be due to involuntary activity in muscles associated with shivering. 
Using fit horses, Mills et al. ${ }^{15}$ showed that high temperature and humidity exacerbate oxidative stress during exercise. Horses performed prolonged variableintensity and short-term high intensity exercises under $20^{\circ} \mathrm{C}, 40 \%$ relative humidity or $30^{\circ} \mathrm{C}, 80 \%$ relative humidity. Horses were unable to complete the exercise protocol in the high heat trial. Correlations $(r=0.85)$ were found between the final stages of exercise in the hot/humid trial and lipid hyperoxides, indicating oxidative stress. Mills concluded that heat and humidity amplified the induced changes in biochemical parameters, which indicate oxidative stress.

Recently, Sial et al. ${ }^{16}$ looked at the effects of aging on substrate oxidation. At similar relative intensities, equivalent to $56 \% \mathrm{VO}_{2} \max$ in the elderly group, carbohydrate was $40 \%$ lower $(p<0.001)$ and fat oxidation was $25-35 \%$ lower $(p<0.05)$ in the elderly group. Sial concluded that the shift in substrate oxidation was caused by age-related changes in skeletal muscle respiratory capacity.

In a study conducted by Hargreaves et al. ${ }^{12}$ subjects were studied during 40minutes of cycling at a workload equivalent to $65 \% \mathrm{VO}_{2}$ max. Trials were randomly performed in ambient temperatures of $20^{\circ} \mathrm{C}(\mathrm{CT})$ and $40^{\circ} \mathrm{C}(\mathrm{HT})$. Glucose rate of appearance and disappearance was measured using a primed infusion of a glucose isotope. Following 40-minutes of exercise, heart rate, rectal temperature, RER, and plasma lactate were all higher $(\mathrm{p}<0.05)$ in HT compared with exercise in CT. Plasma glucose levels were higher following exercise in HT $(\mathrm{p}<0.05)$ due to an increase in hepatic glucose production. Glucose rate of disappearance and metabolic clearance rate 
was not different at any point. Hargreaves concluded that hyperglycemia observed during the heat was caused by in increase in liver glucose without any change in whole body glucose utilization.

Galloway et al. ${ }^{9}$ found that the effects of temperature on exercise capacity follow an inverted $\mathrm{U}$ relationship. During trials in temperatures of $3.6^{\circ} \mathrm{C}, 10.5^{\circ} \mathrm{C}, 20.6^{\circ} \mathrm{C}$ and $30.5^{\circ} \mathrm{C}$, exercise time was the greatest during the $11^{\circ} \mathrm{C}$ trial. RER was the lowest and fat oxidation highest during the $11^{\circ} \mathrm{C}$ trial. In temperatures higher than $11^{\circ} \mathrm{C}, \mathrm{RER}$ increased although carbohydrate oxidation rates were highest $(\mathrm{p}<0.05)$ during the $4^{\circ} \mathrm{C}$ trial. Galloway concluded that the optimal temperature for prolonged exercise from this study was $11^{\circ} \mathrm{C}$.

Starkie et al. ${ }^{18}$ used water cuffs to examine the effects of temperature on metabolism during submaximal exercise. 40 -minutes prior to exercise, each subject had one thigh warmed with $55^{\circ} \mathrm{C}$ water $(\mathrm{HL})$ and the other thigh cooled with $0^{\circ} \mathrm{C}(\mathrm{CL})$ water via water-perfused cuffs and continued wearing them throughout the trial. Subjects performed at $70 \% \mathrm{VO}_{2}$ peak for 20 minutes. Results from muscle biopsy showed that muscle glycogen levels were lower in the HL thigh $(\mathrm{p}<0.05)$. Muscle ATP concentrations were not different post exercise when comparing HL to CL. Starkie concluded that the increase in $\mathrm{CHO}$ utilization was a direct result of elevated muscle temperature and was not secondary to allosteric activity from enzymes mediated by a reduced ATP content. 
A study from Gonzalez-Alonso et al. ${ }^{11}$ used dehydration-induced reductions in blood flow to examine substrate delivery and utilization. Subjects performed two separate trials at $61 \% \mathrm{VO}_{2} \max$ in $35^{\circ} \mathrm{C}$ heat. The first trial (DE) was done until voluntary exhaustion without any hydration and developing hyperthermia $\left(39.7^{\circ} \mathrm{C}\right)$. The second trial (CON) was performed for the same length of time, except fluid ingestion was allowed and core temperatures only reached $38.2^{\circ} \mathrm{C}$. Following 20 -minutes of exercise, leg blood flow was decreased in DE $(p<0.05)$. DE resulted in a lower $(p<0.05)$ FFA uptake, higher glycogen utilization and higher muscle lactate production. Plasma glucose and FFA levels were not different between trials. Gonzalez-Alonso concluded that hyperthermia was the main factor in fatigue in the heat.

In a review article, Febbraio states that ${ }^{3}$ if exercise is submaximal in nature and a $>.5^{\circ} \mathrm{C}$ increase in body temperature is observed, intramuscular carbohydrate utilization is being augmented. He also suggests that when the body is unable to dissipate heat, augmenting the exercise induced rise in core body temperature and perceived effort, a feed forward increase in epinephrine secretion results. This increase in epinephrine further augments glycogen utilization in contracting skeletal muscle. Increased muscle temperature may also impair muscle and metabolic function limiting oxidative phosphorylation in the heat.

In a review article regarding alterations in energy metabolism during heat stress, Febbraio ${ }^{2}$ sites findings by Fink et al. ${ }^{7}$ and Gonzalez-Alonso et al. ${ }^{11}$ that heat stress does not alter plasma free fatty acid, but reduces contracting free fatty acid uptake. 
Febbraio suggests that free fatty acid release by adipocytes may be reduced during exercise in the heat.

\section{Body Composition and Substrate Selection}

To find the optimal intensity to oxidize fats, Looper et al. ${ }^{14}$ had subjects perform at 70,85 and $100 \%$ ventilatory threshold (VT). Subjects were separated into two groups, those with low fat mass $(10.5 \pm 2.3 \%)$ and recreational fitness levels (recfit-lowfat) and those with high fat mass $(27.1 \pm 5 \%)$ and low fitness levels (lowfit-highfat). Fat oxidation was highest at $70 \%$ VT for the lowfit-highfat group and decreased with increased intensities. There were no significant differences between intensities for the recfit-lowfat group. Fat oxidation was not different between groups at $70 \% \mathrm{VT}$, but was significantly lower at $85 \%$ VT and $100 \%$ VT in the lowfit-highfat group. Looper concluded that with increased fitness and decreased fat mass, individuals are better able to maintain higher rates of fat oxidation over a range of moderate intensities.

\section{Gender and Substrate Selection}

Comparing gender and substrate utilization, Tarnopolsky et al. ${ }^{19}$ found that women oxidized significantly more lipid and less protein and carbohydrate compared with the men during exercise at $75 \% \mathrm{VO}_{2}$-peak. Also, after an attempt to increase muscle glycogen through 4 days of carbohydrate loading, women did not increase muscle glycogen stores whereas men did. Tarnopolsky concluded that his data supports previous observations of greater lipid and lower carbohydrate and protein oxidation by women versus men during submaximal endurance exercise. 


\section{Chapter Three: Methodology}

\section{Setting}

All exercise testing took place at The University of Montana, Human Performance Laboratory.

Subjects

Sixteen apparently healthy college aged men participated in the study. Subjects were divided into two groups based on their body composition. Men with $>18 \%$ fat mass $(n=8)$ were placed in the high fat group (group 1 ) and men with $<10 \%$ fat mass $(n=8)$ were placed in the low fat group (group 2). Prior to participation, each subject completed an IRB approved informed consent form.

\section{Descriptive Data}

Prior to testing, the following descriptive data was obtained: age, height $(\mathrm{cm})$ and body weight $(\mathrm{kg})$ using a calibrated digital scale model PS6600T (Belfour Inc., Cedarburg, WI). Residual lung volume was measured using the helium dilution method (Collins Modular Lung Analyzer, Greensboro, NC). Hydrostatic weight was measured with a digital underwater scale (Exertech, Dresbach, MN). Body density was calculated using an average of three underwater weights within 100 grams of each other and corrected for residual volume. Body density was converted to percent fat using the Siri equation ${ }^{17}$. 


\section{Exercise Testing}

For the initial session subjects completed a graded exercise test on a Monark 824E mechanically braked cycle ergometer (Varberg, Sweden) to determine ventilatory threshold (VT) and $\mathrm{VO}_{2}$ max. The graded exercise for VT consisted of 1-minute stages until exhaustion. The first stage was performed at approximately 70 -watts and each subsequent stage consistes of a 15 -watt increase. Cadence was maintained at 70 revolutions per minute. Expired gas was collected and analyzed at 15 -second intervals using a calibrated Parvo Medics metabolic cart (Parvomedics, Inc., Salt Lake City, UT). VT was determined using a combination of the V-slope method, the ventilatory equivalent method and the excess $\mathrm{CO}_{2}$ method ${ }^{10}$.

\section{Trials}

Each subject was asked to refrain from strenuous exercise, caffeine, alcohol, and tobacco for 24-hours prior to the trial. Subjects were asked to keep a 1-day food diary the day before the test and follow it for each subsequent trial. All trials were performed in the morning following a 10-hour fast. Subjects exercised at a work rate equivalent to $90 \%$ of VT for 45 -minutes on a cycle ergometer. Exercise chamber temperature was controlled at $28^{\circ} \mathrm{C}$ for both trials. Subjects received either cooling (WC, $22^{\circ} \mathrm{C}$ ) from the AVAcore hand device or no cooling (NC) in a random repeated measure. Core body temperature was continuously recorded using an Omega data logger and Mon-a-therm (Mallinkrodt Medical, Inc.) rectal probe inserted at least $10 \mathrm{~cm}$. Heart rate was recorded every 10-minutes using a chest strap heart rate monitor (Polar, Port Washington, NY). RPE was recorded every 10-minutes. Blood lactate samples were taken at minute 0,15 , 
25,35 and 45 . RER was recorded at minutes $5,15,25,35$ and 45 . Whole body carbohydrate and fat oxidation were calculated from $\mathrm{VO}_{2}$ and $\mathrm{VCO}_{2}$ measures collected at minutes $5,15,25,35$ and 45 using the Frayn equation ${ }^{8}$. Following the completion of each trial, a passive recovery took place for 10-minutes.

\section{Statistics}

RER, HR, RPE, fat oxidation and CHO oxidation were examined using preplanned comparison between trials for each group individually during minutes $5,15,25$, 35, and 45. Pre-planned comparisons examined differences in RER, HR, RPE, fat oxidation and CHO oxidation at minute 5 vs. 25 and 5 vs. 45 within trials for both groups individually. Temperature was analyzed between groups with pre-planned comparisons between trials at minutes $0,5,15,25,35,45$, and 10 -minutes post. Within each trial preplanned comparisons examined differences between minute 0 vs. 25,0 vs. 45 and 45 vs. 10-minute post for both groups individually. Blood lactate was examined using preplanned comparison between trials for each group individually during minutes $0,15,25$, 35, and 45. Pre-planned comparisons will examine differences in blood lactate at minute 0 vs. 25 and 0 vs. 45 within trials for both groups individually. Significance level was set at $\mathrm{p}<0.05$. 


\section{Chapter Four: Results}

\section{Descriptive Data}

Table 1. Group 1

\begin{tabular}{|c|c|c|c|c|c|c|c|}
\hline Subject & Age & $\begin{array}{c}\text { Ht. } \\
\text { inches }\end{array}$ & $\begin{array}{c}\text { Wt. } \\
\mathrm{kg}\end{array}$ & $\begin{array}{l}\text { \% body fat } \\
\text { Peak VO2 (L/min) }\end{array}$ & VT (L/min) & \% VO2 at VT \\
\hline 9 & 24 & 71.5 & 90.2 & 18.1 & 3.15 & 2.0 & 0.63 \\
\hline 10 & 25 & 69 & 94.6 & 20.6 & 3.60 & 2.2 & 0.61 \\
\hline 11 & 30 & 70.5 & 95.0 & 22.7 & 4.43 & 2.8 & 0.63 \\
\hline 12 & 30 & 68 & 88.2 & 18.1 & 3.51 & 2.2 & 0.61 \\
\hline 13 & 36 & 72 & 104.7 & 26.4 & 4.13 & 2.8 & 0.69 \\
\hline 14 & 37 & 73 & 110.3 & 27 & 3.87 & 2.4 & 0.62 \\
\hline 15 & 19 & 72 & 84.35 & 18.2 & 2.98 & 2.7 & 0.57 \\
\hline 16 & 23 & 71 & 144.8 & 38.7 & 3.49 & 1.9 & 0.56 \\
\hline
\end{tabular}

Table 2. Group 2

\begin{tabular}{|c|c|c|c|c|c|c|c|}
\hline Subject & Age & $\begin{array}{c}\text { Ht. } \\
\text { inches }\end{array}$ & $\begin{array}{c}\text { Wt. } \\
\text { kg }\end{array}$ & $\begin{array}{c}\% \text { body fat } \\
\text { Peak VO2 (L/min) }\end{array}$ & VT (L/min) & \% VO2 at VT \\
\hline 1 & 23 & 70.7 & 77.6 & 4.9 & 4.24 & 2.8 & 0.66 \\
\hline 2 & 32 & 70.3 & 68.1 & 6.2 & 3.76 & 2.5 & 0.66 \\
\hline 3 & 22 & 73.5 & 65.9 & 3.1 & 4.34 & 2.8 & 0.65 \\
\hline 4 & 28 & 66.5 & 67.9 & 6.6 & 4.44 & 2.6 & 0.59 \\
\hline 5 & 20 & 73 & 68.8 & 9.9 & 4.23 & 2.9 & 0.67 \\
\hline 6 & 19 & 66 & 61.1 & 5.2 & 4.07 & 3.0 & 0.74 \\
\hline 7 & 21 & 71 & 66.8 & 5.5 & 4.87 & 2.6 & 0.73 \\
\hline 8 & 19 & 69 & 82.9 & 4.2 & 3.91 & 2.2 & 0.56 \\
\hline
\end{tabular}




\section{CHO Utilization}

For group 1, NC showed significantly greater CHO use at minutes 5 and 25 . NC showed significant decreases in $\mathrm{CHO}$ utilization between minutes 5 and 25, and between minutes 5 and 45. All other pre-planned comparisons were not significantly different.

For group 2, CHO utilization during NC was significantly greater at minutes 5,15 , and 45 compared with WC. During NC, CHO utilization dropped significantly between minutes 5 and 25, and between minutes 5 and 45. All other pre-planned comparisons were not significantly different.

\section{Fat Utilization}

For group 1, WC resulted in significantly greater fat utilization at minutes 5 and 25 .

During both NC and WC, fat utilization increased significantly between minutes 5 and 25 , and between minutes 5 and 45 for group 2 . All other pre-planned comparisons were not significantly different.

For group 2, fat utilization was significantly greater during WC at minutes $5,15,25$, and 45. During both $\mathrm{NC}$ and $\mathrm{WC}$, fat utilization increased significantly between minutes 5 and 25, and between minutes 5 and 45 for group 1. All other pre-planned comparisons were not significantly different. 


\section{RER}

For group 1, NC resulted in significantly higher RER values at minutes 5 and 25 . Both $\mathrm{NC}$ and WC resulted in significant decreases in RER between minutes 5 and 25, and 5 and 45. All other pre-planned comparisons were not significantly different.

For group 2, RER was significantly higher at minutes $5,15,25$, and 45 during NC. Both $\mathrm{NC}$ and WC resulted in significant decreases in RER between minutes 5 and 25, and 5 and 45. All other pre-planned comparisons were not significantly different.

\section{Heart Rate}

For group 1, HR was significantly lower at minute 5 during WC. For both NC and WC, HR increased between minutes 5 and 25 , and between minutes 5 and 45 . All other preplanned comparisons were not significantly different.

For group 2, there were no significant differences between trials at any point. For both NC and WC, HR increased between minutes 5 and 25, and between minutes 5 and 45 . All other pre-planned comparisons were not significantly different.

\section{RPE}

For group 1, RPE was significantly lower during WC at minutes 25 and 45 compared with NC. For both NC and WC, RPE increased between minutes 5 and 25, and between minutes 5 and 45 . All other pre-planned comparisons were not significantly different. 
For group 2, there were no significant differences between trials at any point. For both NC and WC, RPE increased between minutes 5 and 25, and between minutes 5 and 45 . All other pre-planned comparisons were not significantly different.

\section{Temperature}

For group 1, there were no significant differences between $\mathrm{NC}$ and $\mathrm{WC}$ at any point. Both NC and WC resulted in increased rectal temperature between minutes 0 and 25 , minutes 0 and 45 , and decreased rectal temperature between minutes 45 and 10 -minute post. All other pre-planned comparisons were not significantly different.

For group 2, there were no significant differences between $\mathrm{NC}$ and $\mathrm{WC}$ at any point. Both NC and WC resulted in increased rectal temperature between minutes 0 and 25 , and 0 and 45 . There was no significant difference between minutes 45 and 10-minute post for the NC trial. All other pre-planned comparisons were not significantly different.

\section{Lactate}

For group 1, there was a significant difference between NC and WC at minute 45 . WC resulted in significant differences between minutes 5 and 25, but non-significant differences between minutes 5 and 45. NC resulted in significant differences between minutes 5 and 25, and between minutes 5 and 45.

For group 2, there were no significant differences between trials. Both WC and NC resulted in significant differences between minutes 5 and 25, and minutes 5 and 45 . 


\section{References}

1. Brooks, G. A., K. J. Hittelman, J. A. Faulkner, and R. E. Beyer. Temperature, skeletal muscle mitochondrial functions, and oxygen debt. Am J Physiol. 220:1053-1059., 1971.

2. Febbraio, M. A. Alterations in energy metabolism during exercise and heat stress. Sports Med. 31:47-59., 2001.

3. Febbraio, M. A. Does muscle function and metabolism affect exercise performance in the heat? Exerc Sport Sci Rev. 28:171-176., 2000.

4. Febbraio, M. A., M. F. Carey, R. J. Snow, C. G. Stathis, and M. Hargreaves. Influence of elevated muscle temperature on metabolism during intense, dynamic exercise. Am J Physiol. 271:R1251-1255., 1996.

5. Febbraio, M. A., R. J. Snow, C. G. Stathis, M. Hargreaves, and M. F. Carey. Blunting the rise in body temperature reduces muscle glycogenolysis during exercise in humans. Exp Physiol. 81:685-693., 1996.

6. Febbraio, M. A., R. J. Snow, C. G. Stathis, M. Hargreaves, and M. F. Carey. Effect of heat stress on muscle energy metabolism during exercise. $J$ Appl Physiol. 77:2827-2831., 1994.

7. Fink, W. J., D. L. Costill, and P. J. Van Handel. Leg muscle metabolism during exercise in the heat and cold. Eur J Appl Physiol Occup Physiol. 34:183-190., 1975.

8. Frayn, K. N. Calculation of substrate oxidation rates in vivo from gaseous exchange. J Appl Physiol. 55:628-634., 1983. 
9. Galloway, S. D. and R. J. Maughan. Effects of ambient temperature on the capacity to perform prolonged cycle exercise in man. Med Sci Sports Exerc. 29:1240-1249., 1997.

10. Gaskill, S. E., B. C. Ruby, A. J. Walker, O. A. Sanchez, R. C. Serfass, and A. S. Leon. Validity and reliability of combining three methods to determine ventilatory threshold. Med Sci Sports Exerc. 33:1841-1848., 2001.

11. Gonzalez-Alonso, J., J. A. Calbet, and B. Nielsen. Metabolic and thermodynamic responses to dehydration-induced reductions in muscle blood flow in exercising humans. J Physiol. 520:577-589., 1999.

12. Hargreaves, M., D. Angus, K. Howlett, N. M. Conus, and M. Febbraio. Effect of heat stress on glucose kinetics during exercise. J Appl Physiol. 81:1594-1597., 1996.

13. Kozlowski, S., Z. Brzezinska, B. Kruk, H. Kaciuba-Uscilko, J. E. Greenleaf, and K. Nazar. Exercise hyperthermia as a factor limiting physical performance: temperature effect on muscle metabolism. J Appl Physiol. 59:766-773., 1985.

14. Looper, L. and S. E. Gaskill. Effects of Body Fat on Substrate Oxidatin During Aerobic Exercise. Thesis, 2002.

15. Mills, P. C., N. C. Smith, I. Casas, P. Harris, R. C. Harris, and D. J. Marlin. Effects of exercise intensity and environmental stress on indices of oxidative stress and iron homeostasis during exercise in the horse. Eur J Appl Physiol Occup Physiol. 74:60-66., 1996. 
16. Sial, S., A. R. Coggan, R. Carroll, J. Goodwin, and S. Klein. Fat and carbohydrate metabolism during exercise in elderly and young subjects. Am J Physiol. 271:E983-989., 1996.

17. Siri, W. Body Composition From Fluid Spaces and Density: Analysis of Methods. In Brozek J, Henschel A, editors. Techniques For Measuring Body Composition. Washington: National Academy of Sciences, 1961, 223-244.

18. Starkie, R. L., M. Hargreaves, D. L. Lambert, J. Proietto, and M. A. Febbraio. Effect of temperature on muscle metabolism during submaximal exercise in humans. Exp Physiol. 84:775-784., 1999.

19. Tarnopolsky, M. A., S. A. Atkinson, S. M. Phillips, and J. D. MacDougall. Carbohydrate loading and metabolism during exercise in men and women. $J \mathrm{Appl}$ Physiol. 78:1360-1368., 1995.

20. Young, A. J., M. N. Sawka, L. Levine, B. S. Cadarette, and K. B. Pandolf. Skeletal muscle metabolism during exercise is influenced by heat acclimation. $J$ Appl Physiol. 59:1929-1935., 1985. 


\title{
Appendix I Attachments
}

\author{
HUMAN PERFORMANCE LABORATORY \\ Dept of Health and Human Performance \\ UNIVERSITY OF MONTANA \\ Missoula, Montana
}

SUBJECT INFORMATION AND CONSENT FORM

(Print Name)

ID \#

Today's Date:

Month $\frac{}{\text { Day }}$ Year

Participant

\section{EFFECTS OF PERIPHERAL COOLING ON MUSCLE FUEL UTHLIZATION DURING MODERATE EXERCISE}

\author{
STUDY DIRECTOR: Brent Ruby, Ph.D. (406) 243-2117 University of Montana \\ STUDY SPONSOR: AVA core Technologies (650) 321-0824
}

This consent forn may contain words that are new to you. If you read any words that are not clear to you, please ask the person who gave you this form to explain them to you.

\section{PURPOSE OF THE RESEARCH}

- You are being asked to take part in a research study to exarnine the effects of hand/arm cooling on measurements of body temperature and metabolism during two sessions of moderate intensity exercise.

- You have been chosen because you are 18-50 years of age, healthy, and a body fat

$<10 \%$ or with a body fat $>18 \%$.

- During this study you will be performing two 45-minute exercise sessions of a submaximal, moderate intensity in a controlled environment of $75^{\circ} \mathrm{F}$.

\section{PROCEDURES}

On your first visit to the lab we will measure your height and weight and body fat.

Body fat will be determined by using hydrostatic weighing. Body density will be calculated using an average of 3 underwater weights within 100 grams of each other. Body fat will be determined from the average body density. Residual lung volume will be determined using the helium dilution method.

If your percent body fat values are less than $10 \%$ or greater that $18 \%$, you are eligible for participation in the study.

On your second visit, you will be asked to perform the following exercise test:

A maximal treadmill test (cycling) to determine your level of aerobic fitness. The performance of a maximal test allows the tester to determine the participant's maximal volume of oxygen breathed in, which is a measure of fitness. This test will also allow us to determine your ventilatory threshold, which will allow us to compute the speed and grade for your two heated exercise sessions. This testing will take approximately I hour. 
2. You will receive information concerning your maximal aerobic capacity and ventilatory threshold, which you may compare with norms for your age, sex and sport. There are no other direct benefits to the participants in the study.

\section{CONFIDENTIALITY}

1. Your records will be kept private and will not be released without your consent except as required by law.

2. Only the researcher and his research assistants will have access to the files.

3. Your identity will be kept confidential.

4. If the results of this study are written in a scientific journal or presented at a scientific meeting, your name will not be used.

5. All data, identified only by an anonymous ID \#, will be stored in our laboratory.

6. Your signed consent form and information sheet will be stored in a locked office separate from the data.

\section{COMPENSATION FOR INJURY}

Although we believe that the risk of taking part in this study is minimal, the following liability statement is required in all University of Montana consent forms.

"In the event that you are injured as a result of this research you should individually seek appropriate medical treatment. If the injury is caused by negligence of the University or any of its employees, you may be entitled to reimbursement pursuant to the Comprehensive State Insurance Plan established by the Department of Administration under the authority of M.C.A., Tille 2. Chapter 9. In the event of a claim for such injury, further information may be obtained from the University's Claim representative or University Legal Counsel,"

\section{VOLUNTARY PARTICIPATION/WITHDRAWAL}

1. You have the right to request that a test be stopped at any time.

2. Your decision to take part in this research study is entirely voluntary.

3. You may refuse to take part in or you may withdraw from the study at any time without penalty or loss of benefits to which you are normally entitled.

4. You may leave the study for any reason.

You may be asked to leave the study for any of the following reasons:

1. Failure to follow the study investigator's instructions.

2. A serious adverse reaction, which may require evaluation.

3. The study director/investigator thinks it is in the best interest of your health and welfare.

4. The study is terminated.

\section{QUESTIONS}

- You may wish to discuss this with others before you agree to take part in this study.

- If you have any questions about the research now or during the study contact: Brent Ruby (406)

243-2117.

- If you have any questions regarding your rights as a research subject, you may contact the Chairman, J.A. Rudbach, of the IRB through the Research Office at the University of Montana at $243-6670$. 
On your third and fourth visit we will measure your responses during a 45 minute exercise trial in a climate controlled room (approximately $75^{\circ} \mathrm{F}$ ). This trial will proceed on a morning after a 12 hour fast. Before the exercise trial, you will place a flexible rectal thermometer so that your core body temperature can be monitored throughout each trial. During the exercise, one arm/hand will be kept cool using a cooling device that creates a low-pressure environment to draw blood into the hand and cools that blood by absorbing heat from the overlying skin. We will also ask you to rate your level of fatigue during the exercise using a 6-20 number scale. Your heart rate will be measured during the exercise using a chest strap heart rate monitor. During the exercise, a small blood sample will be periodically obtained from your finger tip (every 10-minutes) to allow us to measure blood lactate. During the exercise trials, you will not be provided with any water until the exercise period ends as it enhances body cooling. As a result, it is anticipated that you will get thirsty during your participation. Periodically, you will wear a mouthpiece and nose clip so that samples of your exhaled air can be collected and analyzed to determine the amount of oxygen your body is consuming during exercise. You will be asked to repeat the same exercise but without the cooling device. All other measurements listed above will be collected during both of the 45-minute trials. It is expected that these two visits to our lab will take approximately 1 to 1 $1 / 2$ hours of your time..

\section{LOCATION AND LENGTH OF TIME REQUIRED}

The study will take place at the in the Human Performance Laboratory in McGill Hall (First Floor - enter main doors, go straight through lobby, then enter lab via first door to the right.)

\section{PAYMENT}

There is no payment for participation.

\section{RISK/DISCOMFORTS}

1. Mild discomfort may result during and after the exercise. These discomforts include shortness of breath, tired or sore legs, nausea and possibility of vomiting.

2. Muscle soreness after the tests may occur as a result of the exercise, but should not persist.

3. Certain changes in body function take place when any person exercises. Some of these changes are normal and others are abnormal. Abnormal changes may occur in blood pressures, heart rate, heart rhythm or extreme shortness of breath. Vary rare instances of heart attack have occurred, as with other moderately strenuous exercise activities. Every effort will be made to minimize possible problems by the preliminary evaluation and constant surveillance during testing. Equipment and trained personnel are available to deal with unusual situations should they arise. A trained CPR technician will be on hand at all times and the laboratory has standard emergency procedures should any potential need arise.

4. Mild symptoms of dehydration such as headache and general fatigue may result during and after the exercise. To minimize the risk of excessive dehydration, your body temperature will be monitored continuously during exercise. Immediately after the exercise sessions, sports drinks or juices (electrolytes) along with water will be provided to you.

5. You will be informed of any new findings that may affect your decision to remain in the study.

6. During any of the exercise tests should symptoms, such as chest discomfort, unusual shortness of breath or other abnormal findings develop, the exercise physiologist conducting the research will terminate the test. Guidelines by the American College of Sports Medicine will be followed to determine when a test should be stopped.

\section{BENEFITS OF PARTICIPATING IN THIS STUDY}

1. There is no promise that you will receive any benefit from taking part in this study. 


\section{SUBJECT'S STATEMENT OF CONSENT}

I have read the above description of this research study. I have been informed of the risks and benefits involved, and all my questions have been answered to my satisfaction. Furthernore, I have been assured that a member of the research team will also answer any future questions I may have. I voluntarily agree to take part. I understand I will receive a copy of this consent form.

Printed (Typed) Name of Subject

Subject's Signature

Date

\section{SUBJEC'T'S STATEMENT OF CONSENT TO BE PHOTOGRAPHED DURING DATA} COLLECTION

I provide my consent to be photographed during periods of the data collection. I realize that these digital images may be used during presentation of the data at regional and national meetings.

Subject's Signature

Date

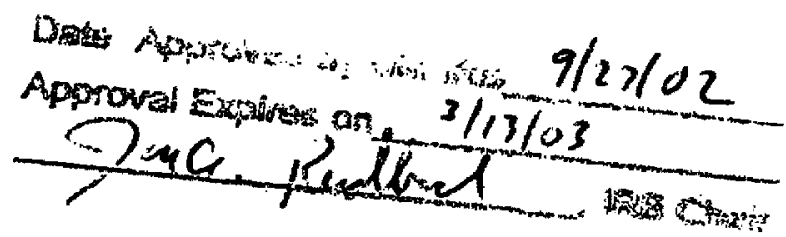




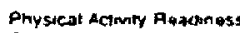
Questionnaurg. PAR. irevisong iggd

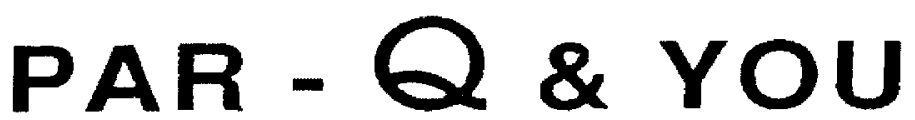

(A Ouestionnaire for People Aged 15 to 69)

Regular physical activily is tun and healthy. and increasingly more people are starting to become more active every day Being more active is very sale for most people. However, some people should check with their doctor betore they start becnming much more physically active.

If you are planning to become much more physically active than you are now, slart by answering the seven questions in the box below. If you are between the ages of is and 69, the PAR-Q will tell you if you should check with your doclor before you start. II you are over 69 years ol age. and you are not used to being very active, check with your doctor.

Common sense is your best guide when you answer these questions. Please read the questions caraiully and answer each one honestly: check YES or NO

\begin{tabular}{|lllll}
\hline YES & NO & & \\
$\square$ & $\square$ & 1. & Has your doctor ever said that you have a heart condition and that you should only do physical activity \\
recommended by a doctor? & \\
$\square$ & $\square$ & 2. & Do you feel pain in your chest when you do physical activity? \\
$\square$ & $\square$ & 3. & In the past month, have you had chest pain when you were not doing physical aclivity? \\
$\square$ & $\square$ & 4. & Do you lose your balance because of dizziness or do you ever lose consciousness? \\
$\square$ & $\square$ & 5. & Do you have a bone or joint problent that could be made worse by a change in your physical activity? \\
$\square$ & $\square$ & 6. & is your doctor currently prescribing drugs (for example, water pills) for your blood pressure or heart condition? \\
$\square$ & $\square$ & 7. & Do you know of any other reason why you should not do physical activity?
\end{tabular}

\begin{tabular}{|c|c|}
\hline you & $\begin{array}{l}\text { Talk with your doctor by phone or in person BEFOAE you start becoming much more physically active or BEFORE yOu have a } \\
\text { fitness appraisal, Tell your doctor about the PAR-O and which questions you answered YES. } \\
\text { - You may be able to do any activily you wam-as long as you start slowty and build up gradually. Or, you may need to restrict } \\
\text { your actwities to those which are sale tor you. Talk with your doctor about the kinds of activities you wish to participate in } \\
\text { and lotlow hisher advice. } \\
\text { - Find out which community programs are sate and helpful for you. }\end{array}$ \\
\hline
\end{tabular}

\section{NO to all questions}

If you answered NO honestly 10 all PAR-O questions, you can be reasonably sure that you can:

- star becoming much more physically active-begin stowly and build uo gradually. This is the salest and easiest way to go.

- take pan in a litness appraisa-this is an exceltent way to determine your basic fitness so that you can plan the best way tor you to five actively.

DELAY geCOMing MUCH MORE aCTIVE;

- if you are not feeling well because of a temporary itiness such as a cold or a fever - wait until you leel benter; or

- if you are or may be pregnant-talk to your doctor betore you start becoming more active.

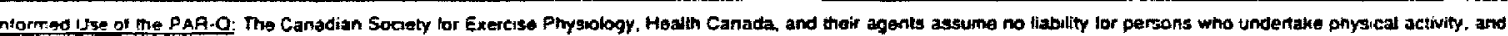
il in doubt atter completing thrs questionnare, conșull your doetor proc to pnysical activity.

You are encouraged to copy the PAA-O but only if you use the entire form

I have read, understood and completed this questionnaire. Any questions I had were answered to my full satisfaction. MAME

STMNATUAE

DATE

SIGMATUAE OF PARENT

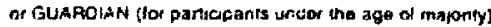

WITNESS

Q Canaditn Socien for Exerclso Physiotogy

Suciele canadienne de physiovgle de lexercice

Supported by:

Meallh Sarto 


\section{Appendix II: Statistics}

\section{Group 1 RER}

Type III Sums of Squares

\begin{tabular}{|c|c|c|c|c|c|c|c|}
\hline Source & df & Sum of Squares & Mean Square & F-Value & P-Value & G-G & $H-F$ \\
\hline Subject & 7 & .031 & .004 & & & & \\
\hline Trial & 1 & .003 & .003 & 3.283 & .1129 & .1129 & .1129 \\
\hline Trial * Subject & 7 & .007 & .001 & & & & \\
\hline time & 4 & .015 & .004 & 15.590 & .0001 & .0002 & .0001 \\
\hline time Subject & 28 & .007 & $2.369 \mathrm{E}-4$ & & & & \\
\hline Trial* time & 4 & .003 & .001 & 6.469 & .0008 & .0041 & .0008 \\
\hline Trial * time * $\mathrm{S}$ & 28 & .003 & $1.052 E-4$ & & & & \\
\hline
\end{tabular}

Dependent: RER

Means Table

Effect: Trial

Dependent: RER

\begin{tabular}{|c|c|c|c|c|}
\hline & Count & Mean & Std. Dev. & Std. Error \\
\hline with & 40 & .903 & .030 & .005 \\
\hline without & 40 & .915 & .027 & .004 \\
\hline
\end{tabular}

\section{Means Table}

Effect: time

Dependent: RER

\begin{tabular}{l|r|r|r|r|}
\multicolumn{1}{c}{ Count } & \multicolumn{2}{c}{ Mean } & Std. Dev. & Std. Error \\
\cline { 2 - 5 } $5 \mathrm{~min}$ & 16 & .933 & .034 & .008 \\
\hline $15 \mathrm{~min}$ & 16 & .912 & .026 & .006 \\
\hline $25 \mathrm{~min}$ & 16 & .908 & .023 & .006 \\
\hline $35 \mathrm{~min}$ & 16 & .898 & .023 & .006 \\
\cline { 2 - 5 } $45 \mathrm{~min}$ & 16 & .894 & .026 & .006 \\
\cline { 2 - 5 } & & & &
\end{tabular}

\section{Means Table \\ Effect: Trial * time \\ Dependent: RER}

with. $5 \mathrm{~min}$ with, $15 \mathrm{~min}$ with, $25 \mathrm{~min}$ with, $35 \mathrm{~min}$ with, 45 min without, $5 \mathrm{~min}$ without, $15 \mathrm{~min}$ without, $25 \mathrm{~min}$ without, $35 \mathrm{~min}$ without, $45 \mathrm{~min}$

\begin{tabular}{|c|c|c|c|}
\hline Count & Mean & Std. Dev. & Std. Error \\
\hline 8 & .916 & .036 & .013 \\
\hline 8 & .911 & .031 & .011 \\
\hline 8 & .899 & .025 & .009 \\
\hline 8 & .897 & .027 & .010 \\
\hline 8 & .890 & .031 & .011 \\
\hline 8 & .949 & .023 & .008 \\
\hline 8 & .914 & .022 & .008 \\
\hline 8 & .917 & .019 & .007 \\
\hline 8 & .898 & .019 & .007 \\
\hline 8 & .899 & .021 & .008 \\
\hline
\end{tabular}




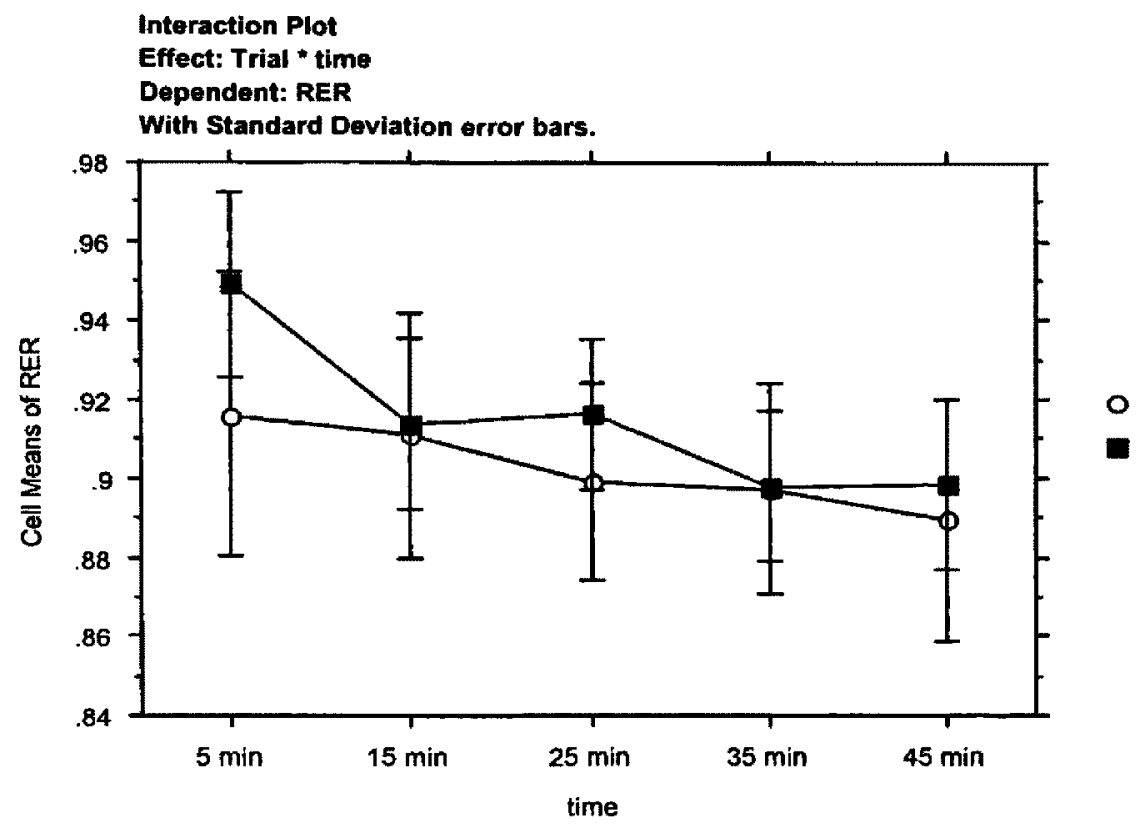

Comparison 1

Effect: Trial * Time

\begin{tabular}{|l|r|}
\hline With min 5 vs. Without min 5 \\
\hline df & 1 \\
\hline Sum of squares & .004 \\
\hline Mean square & .004 \\
\hline F-Value & 41.233 \\
\hline P-Value & .0001 \\
\hline G-G & .0001 \\
\hline H-F & .0001 \\
\hline
\end{tabular}

Comparison 3

Effect: Trial ${ }^{*}$ Time

\begin{tabular}{|l|r|}
\hline \multicolumn{2}{|l|}{ With min 25 vs. Without $\min 25$} \\
\hline df & 1 \\
\hline Sum of squares & .001 \\
\hline Mean square & .001 \\
\hline F-Value & 11.160 \\
\hline P-Value & .0024 \\
\hline G-G & .0071 \\
\hline H-F & .0024 \\
\hline
\end{tabular}

Comparison 2 Effect: Trial * Time

\begin{tabular}{|l|r|}
\hline \multicolumn{2}{|l|}{ With min 15 vs. Without min 15 } \\
\hline df & 1 \\
\hline Sum of squares & $3.655 \mathrm{E}-5$ \\
\hline Mean square & $3.655 \mathrm{E}-5$ \\
\hline F-Value & .348 \\
\hline P-Value & .5602 \\
\hline G-G & .4793 \\
\hline H-F & .5602 \\
\hline
\end{tabular}

Comparison 4

Effect: Trial * Time

\begin{tabular}{|l|r|}
\hline \multicolumn{2}{|l|}{ With min 35 vs. Without $\min 35$} \\
\hline df & 1 \\
\hline Sum of squares & $1.896 \mathrm{E}-6$ \\
\hline Mean square & $1.896 \mathrm{E}-6$ \\
\hline F-Value & .018 \\
\hline P-Value & .8941 \\
\hline G-G & .8032 \\
\hline H-F & .8941 \\
\hline
\end{tabular}


Comparison 5

Effect: Trial $*$ Time

\begin{tabular}{|l|r|}
\hline With min 45 vs. Without min45 \\
\hline df & 1 \\
\hline Sum of squares & $3.228 \mathrm{E}-4$ \\
\hline Mean square & $3.228 \mathrm{E}-4$ \\
\hline F-Value & 3.070 \\
\hline P-Value & .0907 \\
\hline G-G & .1044 \\
\hline H-F & .0907 \\
\hline
\end{tabular}

Comparison 7

Effect: Trial * Time

\begin{tabular}{|l|r|}
\hline \multicolumn{2}{|l|}{ With min 5 vs. With $\min 45$} \\
\hline df & 1 \\
\hline Sum of squares & .003 \\
\hline Mean square & .003 \\
\hline F-Value & 27.083 \\
\hline P-Value & .0001 \\
\hline G-G & .0002 \\
\hline H-F & .0001 \\
\hline
\end{tabular}

Comparison 6

Effect: Trial * Time

\begin{tabular}{|l|r|}
\hline \multicolumn{2}{|l|}{ With min 5 vs. With min 25 } \\
\hline df & 1 \\
\hline Sum of squares & .001 \\
\hline Mean square & .001 \\
\hline F-Value & 10.816 \\
\hline P-Value & .0027 \\
\hline G-G & .0078 \\
\hline H-F & .0027 \\
\hline
\end{tabular}

Comparison 8

Effect: Trial * Time

\begin{tabular}{|l|r|}
\hline \multicolumn{2}{|l|}{ Without min 5 vs. Without min 25 } \\
\hline df & 1 \\
\hline Sum of squares & .004 \\
\hline Mean square & .004 \\
\hline F-Value & 40.570 \\
\hline P-Value & .0001 \\
\hline G-G & .0001 \\
\hline H-F & .0001 \\
\hline
\end{tabular}

\section{Comparison 9}

Effect: Trial * Time

\begin{tabular}{|l|r|}
\hline \multicolumn{2}{|l|}{ Without min 5 vs. Without $\min 45$} \\
\hline df & 1 \\
\hline Sum of squares & .010 \\
\hline Mean square & .010 \\
\hline F-Value & 97.481 \\
\hline P-Value & .0001 \\
\hline G-G & .0001 \\
\hline H-F & .0001 \\
\hline
\end{tabular}




\section{Group $1 \mathrm{HR}$}

Type III Sums of Squares

\begin{tabular}{|c|c|c|c|c|c|c|c|}
\hline Source & $d f$ & Sum of Squares & Mean Square & F-Value & P-Value & G-G & $\mathrm{H}-\mathrm{F}$ \\
\hline Subject & 7 & 12279.934 & 1754.276 & & & & \\
\hline Trial & 1 & 20.211 & 20.211 & .335 & .5810 & .5810 & .5810 \\
\hline Trial * Subject & 7 & 422.714 & 60.388 & & & & \\
\hline time & 4 & 4327.352 & 1081.838 & 39.892 & .0001 & .0001 & .0001 \\
\hline time * Subject & 28 & 759.332 & 27.119 & & & & \\
\hline Trial * time & 4 & 41.309 & 10.327 & 1.129 & .3631 & .3518 & .3596 \\
\hline Trial * time * $\mathrm{S} \ldots$ & 28 & 256.183 & 9.149 & & & & \\
\hline
\end{tabular}

Dependent: HR

\section{Means Table \\ Effect: Trial \\ Dependent: HR}

\begin{tabular}{|c|c|c|c|c|}
\hline & Count & Mean & Std. Dev. & Std. Error \\
\hline with & 40 & 133.508 & 15.202 & 2.404 \\
\hline without & 40 & 134.514 & 15.254 & 2.412 \\
\hline
\end{tabular}

\begin{tabular}{|c|c|c|c|c|}
\hline \multicolumn{5}{|c|}{$\begin{array}{l}\text { Means Table } \\
\text { Effect: time } \\
\text { Dependent: HR }\end{array}$} \\
\hline & Count & Mean & Std. Dev. & Std. Error \\
\hline $5 \mathrm{~min}$ & 16 & 122.572 & 12.415 & 3.104 \\
\hline $15 \mathrm{~min}$ & 16 & 129.618 & 13.829 & 3.457 \\
\hline $25 \mathrm{~min}$ & 16 & 134.564 & 12.848 & 3.212 \\
\hline $35 \mathrm{~min}$ & 16 & 140.368 & 14.657 & 3.664 \\
\hline $45 \mathrm{~min}$ & 16 & 142.933 & 13.905 & 3.476 \\
\hline
\end{tabular}

Means Table

Effect: Trial * time

Dependent: HR

with, $5 \mathrm{~min}$

with, 15 min

with, 25 min

with, $35 \mathrm{~min}$

with, $45 \mathrm{~min}$

without, 5 min

without, $15 \mathrm{~min}$

without, 25 min

without, $35 \mathrm{~min}$

without, $45 \mathrm{~min}$

\begin{tabular}{|c|c|c|c|}
\hline Count & Mean & Std. Dev. & Sid. Error \\
\hline 8 & 120.681 & 12.265 & 4.336 \\
\hline 8 & 129.196 & 12.984 & 4.591 \\
\hline 8 & 134.304 & 13.424 & 4.746 \\
\hline 8 & 140.296 & 15.308 & 5.412 \\
\hline 8 & 143.065 & 13.671 & 4.834 \\
\hline 8 & 124.464 & 13.102 & 4.632 \\
\hline 8 & 130.040 & 15.518 & 5.487 \\
\hline 8 & 134.824 & 13.168 & 4.656 \\
\hline 8 & 140.440 & 15.032 & 5.315 \\
\hline 8 & 142.801 & 15.080 & 5.331 \\
\hline
\end{tabular}




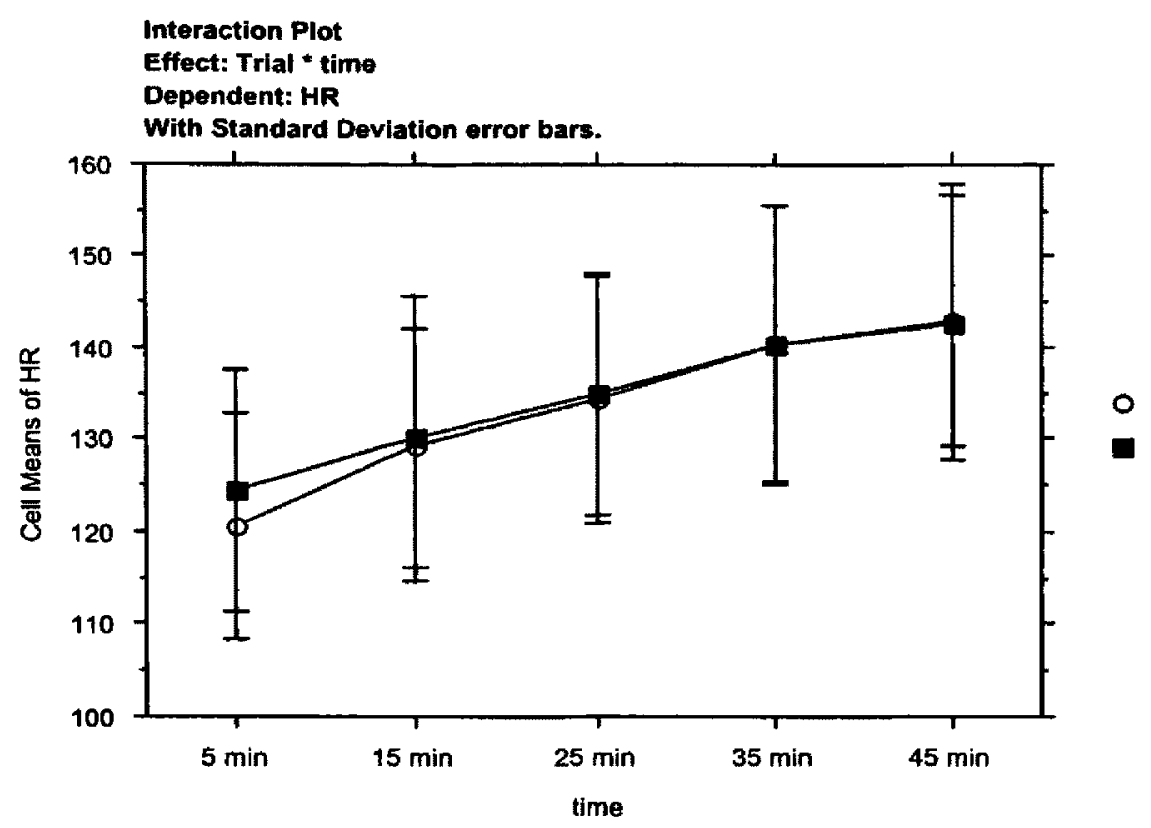

Comparison 1

Effect: Trial * Time

\begin{tabular}{|l|r|}
\hline \multicolumn{2}{|l|}{ With min 5 vs. Without min 5 } \\
\hline df & 1 \\
\hline Sum of squares & 57.229 \\
\hline Mean square & 27.229 \\
\hline F-Value & 6.255 \\
\hline P-Value & .0185 \\
\hline G-G & .0410 \\
\hline H-F & .0292 \\
\hline
\end{tabular}

Comparison 2

Effect: Trial * Time

\begin{tabular}{|l|r|}
\hline \multicolumn{2}{|l|}{ With min 15 vs. Without min 15 } \\
\hline df & 1 \\
\hline Sum of squares & 2.848 \\
\hline Mean square & 2.848 \\
\hline F-Value & .311 \\
\hline P-Value & .58314 \\
\hline G-G & .4387 \\
\hline H-F & .5113 \\
\hline
\end{tabular}

\section{Comparison 3}

Effect: Trial * Time

\begin{tabular}{|l|r|}
\hline With $\min 25$ vs. Without $\min 25$ \\
\hline df & 1 \\
\hline Sum of squares & 1.082 \\
\hline Mean square & 1.082 \\
\hline F-Value & .118 \\
\hline P-Value & .7335 \\
\hline G-G & .5573 \\
\hline H-F & .6494 \\
\hline
\end{tabular}

Comparison 4 Effect: Trial * Time

\begin{tabular}{|l|r|}
\hline \multicolumn{2}{|l|}{ With $\min 35$ vs. Without $\min 35$} \\
\hline df & 1 \\
\hline Sum of squares & .083 \\
\hline Mean square & .083 \\
\hline F-Value & .009 \\
\hline P-Value & .9250 \\
\hline G-G & .7693 \\
\hline H-F & .8604 \\
\hline
\end{tabular}




\section{Comparison 5}

Effect: Trial * Time

\begin{tabular}{|l|r|}
\hline \multicolumn{2}{|l|}{ With $\min 45$ vs. Without $\min 45$} \\
\hline df & 1 \\
\hline Sum of squares & .278 \\
\hline Mean square & .278 \\
\hline F-Value & .030 \\
\hline P-Value & .8628 \\
\hline G-G & .6857 \\
\hline H-F & .7838 \\
\hline
\end{tabular}

Comparison 7

Effect: Trial * Time

\begin{tabular}{|l|r|}
\hline \multicolumn{2}{|l|}{ With min 5 vs. With $\min 45$} \\
\hline df & 1 \\
\hline Sum of squares & 2004.129 \\
\hline Mean square & 2004.129 \\
\hline F-Value & 219.045 \\
\hline P-Value & .0001 \\
\hline G-G & .0001 \\
\hline H-F & .0001 \\
\hline
\end{tabular}

Comparison 6

Effect: Trial * Time

\begin{tabular}{|l|r|}
\hline \multicolumn{2}{|l|}{ With min 5 vs. With $\min 25$} \\
\hline df & 1 \\
\hline Sum of squares & 742.290 \\
\hline Mean square & 742.290 \\
\hline F-Value & 81.130 \\
\hline P-Value & .0001 \\
\hline G-G & .0001 \\
\hline H-F & .0001 \\
\hline
\end{tabular}

Comparison 8

Effect: Trial * Time

\begin{tabular}{|l|r|}
\hline \multicolumn{2}{|l|}{ Without min 5 vs. Without min 25 } \\
\hline df & 1 \\
\hline Sum of squares & 429.318 \\
\hline Mean square & 429.318 \\
\hline F-Value & 46.923 \\
\hline P-Value & .0001 \\
\hline G-G & .0001 \\
\hline H-F & .0001 \\
\hline
\end{tabular}

\section{Comparison 9}

Effect: Trial * Time

\begin{tabular}{|l|r|}
\hline \multicolumn{2}{|l|}{ Without min 5 vs. Without min 45 } \\
\hline df & 1 \\
\hline Sum of squares & 1345.056 \\
\hline Mean square & 1345.056 \\
\hline F-Value & 147.010 \\
\hline P-Value & .0001 \\
\hline G-G & .0001 \\
\hline H-F & .0001 \\
\hline
\end{tabular}




\section{Group 1 Fat utilization}

Type III Sums of Squares

\begin{tabular}{|c|c|c|c|c|c|c|c|}
\hline Source & df & Sum of Squares & Mean Square & F-Value & P-Value & $G-G$ & $\mathrm{H}-\mathrm{F}$ \\
\hline Subject & 7 & 82.936 & 11.848 & & & & \\
\hline Trial & 1 & 4.023 & 4.023 & 4.857 & .0634 & .0634 & .0634 \\
\hline Trial - Subject & 7 & 5.798 & .828 & & & & \\
\hline time & 4 & 33.785 & 8.446 & 20.597 & .0001 & .0001 & .0001 \\
\hline time * Subject & 28 & 11.482 & .410 & & & & \\
\hline Trial * time & 4 & 4.265 & 1.066 & 4.562 & .0058 & .0402 & .0277 \\
\hline Trial ${ }^{*}$ time ${ }^{*} \mathrm{~S} .$. & 28 & 6.545 & .234 & & & & \\
\hline
\end{tabular}

Dependent: Fat oxidation ( $\mu \mathrm{mol} / \mathrm{kg} / \mathrm{min}$ )

\section{Means Table}

Effect: Trial

Dependent: Fat oxidation ( $\mu \mathrm{mol} / \mathrm{kg} / \mathrm{min}$ )

\begin{tabular}{|c|c|c|c|c|}
\hline & Count & Mean & Std. Dev. & Std. Error \\
\hline with & 40 & 4.058 & 1.347 & .213 \\
\hline without & 40 & 3.609 & 1.378 & .218 \\
\hline
\end{tabular}

\section{Means Table}

Effect: time

Dependent: Fat oxidation ( $\mu \mathrm{mol} / \mathrm{kg} / \mathrm{min}$ )

\begin{tabular}{|c|c|c|c|c|}
\hline & Count & Mean & Std. Dev. & Std. Error \\
\hline $5 \mathrm{~min}$ & 16 & 2.724 & 1.330 & .333 \\
\hline $15 \mathrm{~min}$ & 16 & 3.581 & 1.156 & .289 \\
\hline $25 \mathrm{~min}$ & 16 & 3.939 & 1.288 & .322 \\
\hline $35 \mathrm{~min}$ & 16 & 4.376 & 1.070 & .267 \\
\hline $45 \mathrm{~min}$ & 16 & 4.549 & 1.327 & .332 \\
\hline
\end{tabular}

\section{Means Table}

Effect: Trial * time

Dependent: Fat oxidation ( $\mu \mathrm{mol} / \mathrm{kg} / \mathrm{min})$

\begin{tabular}{|c|c|c|c|c|}
\hline & Count & Mean & Std. Dev. & Std. Error \\
\hline with, $5 \mathrm{~min}$ & 8 & 3.329 & 1.335 & .472 \\
\hline with, $15 \mathrm{~min}$ & 8 & 3.680 & 1.412 & .499 \\
\hline with, $25 \mathrm{~min}$ & 8 & 4.303 & 1.362 & .482 \\
\hline with, $35 \mathrm{~min}$ & 8 & 4.335 & 1.098 & .388 \\
\hline with, $45 \mathrm{~min}$ & 8 & 4.644 & 1.397 & .494 \\
\hline without, $5 \mathrm{~min}$ & 8 & 2.120 & 1.084 & .383 \\
\hline without, $15 \mathrm{~min}$ & 8 & 3.481 & .921 & .326 \\
\hline without, $25 \mathrm{~min}$ & 8 & 3.575 & 1.181 & .418 \\
\hline without, $35 \mathrm{~min}$ & 8 & 4.416 & 1.115 & .394 \\
\hline without, $45 \mathrm{~min}$ & 8 & 4.455 & 1.342 & .474 \\
\hline
\end{tabular}




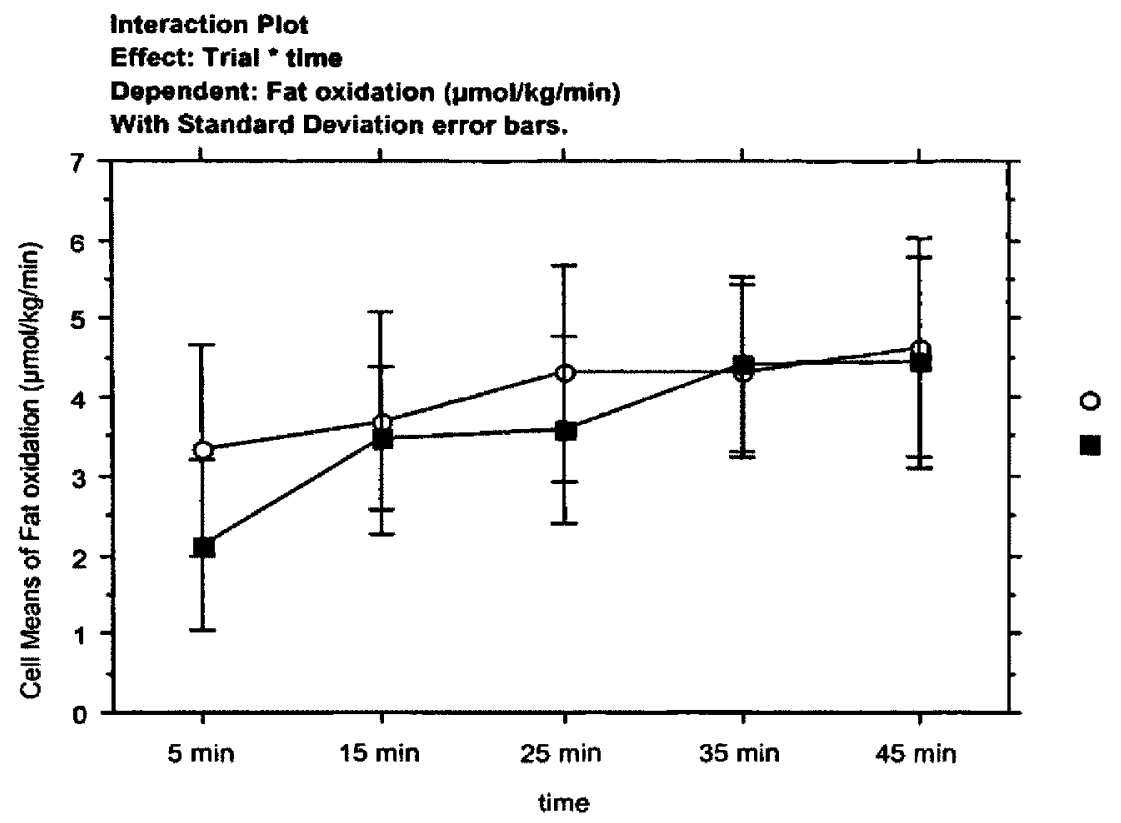

Comparison 1

Effect: Trial * Time

\begin{tabular}{|l|r|}
\hline \multicolumn{2}{|l|}{ With min 5 vs. Without min 5 } \\
\hline df & 1 \\
\hline Sum of squares & 5.844 \\
\hline Mean square & 5.844 \\
\hline F-Value & 25.004 \\
\hline P-Value & .0001 \\
\hline G-G & .0023 \\
\hline H-F & .0010 \\
\hline
\end{tabular}

Comparison 2

Effect: Trial * Time

\begin{tabular}{|l|r|}
\hline With min 15 vs. Without min 15 \\
\hline df & 1 \\
\hline Sum of squares & .158 \\
\hline Mean square & .158 \\
\hline F-Value & .676 \\
\hline P-Value & .4179 \\
\hline G-G & .3003 \\
\hline H-F & .3309 \\
\hline
\end{tabular}

\section{Comparison 3}

Effect: Trial * Time

\begin{tabular}{|l|r|}
\hline \multicolumn{2}{|l|}{ With $\min 25$ vs. Without $\min 25$} \\
\hline df & 1 \\
\hline Sum of squares & 2.117 \\
\hline Mean square & 2.117 \\
\hline F-Value & 9.057 \\
\hline P-Value & .0055 \\
\hline G-G & .0260 \\
\hline H-F & .0195 \\
\hline
\end{tabular}

Comparison 4 Effect: Trial * Time

\begin{tabular}{|l|r|}
\hline \multicolumn{2}{|l|}{ With $\min 35$ vs. Without $\min 35$} \\
\hline df & 1 \\
\hline Sum of squares & .026 \\
\hline Mean square & .026 \\
\hline F-Value & .113 \\
\hline P-Value & .4179 \\
\hline G-G & .3003 \\
\hline H-F & .3309 \\
\hline
\end{tabular}


Comparison 5

Effect: Trial * Time

\begin{tabular}{|l|r|}
\hline With min 45 vs. Without min45 \\
\hline df & 1 \\
\hline Sum of squares & .143 \\
\hline Mean square & .143 \\
\hline F-Value & .610 \\
\hline P-Value & .4415 \\
\hline G-G & .3135 \\
\hline H-F & .3464 \\
\hline
\end{tabular}

Comparison 7

Effect: Trial * Time

\begin{tabular}{|l|r|}
\hline \multicolumn{2}{|l|}{ With min 5 vs. With min 45 } \\
\hline df & 1 \\
\hline Sum of squares & 6.917 \\
\hline Mean square & 6.917 \\
\hline F-Value & 25.593 \\
\hline P-Value & .0001 \\
\hline G-G & .0013 \\
\hline H-F & .0005 \\
\hline
\end{tabular}

Comparison 6

Effect: Trial $*$ Time

\begin{tabular}{|l|r|}
\hline With min 5 vs. With $\min 25$ \\
\hline df & 1 \\
\hline Sum of squares & 3.793 \\
\hline Mean square & 3.793 \\
\hline F-Value & 16.227 \\
\hline P-Value & .0004 \\
\hline G-G & .0075 \\
\hline H-F & .0043 \\
\hline
\end{tabular}

\section{Comparison 8 \\ Effect: Trial * Time}

\begin{tabular}{|l|r|}
\hline \multicolumn{2}{|l|}{ Without min 5 vs. Without $\min 25$} \\
\hline $\mathrm{df}$ & 1 \\
\hline Sum of squares & 8.468 \\
\hline Mean square & 8.468 \\
\hline F-Value & 36.230 \\
\hline P-Value & .0001 \\
\hline G-G & .0007 \\
\hline H-F & .0002 \\
\hline
\end{tabular}

\section{Comparison 9}

\section{Effect: Trial * Time}

\begin{tabular}{|l|r|}
\hline Without min 5 vs. Without min 45 \\
\hline df & 1 \\
\hline Sum of squares & 21.809 \\
\hline Mean square & 21.809 \\
\hline F-Value & 93.306 \\
\hline P-Value & .0001 \\
\hline G-G & .0001 \\
\hline H-F & .0001 \\
\hline
\end{tabular}




\section{Group $1 \mathrm{CHO}$}

Type III Sums of Squares

\begin{tabular}{|c|c|c|c|c|c|c|c|}
\hline Source & df & Sum of Squares & Mean Square & F-Value & P-Value & G-G & $\mathrm{H}-\mathrm{F}$ \\
\hline Subject & 7 & 71120.364 & 10160.052 & & & & \\
\hline Trial & 1 & 675.064 & 675.064 & 3.835 & .0910 & .0910 & .0910 \\
\hline Trial* Subject & 7 & 1232.048 & 176.007 & & & & \\
\hline time & 4 & 2344.810 & 586.203 & 6.290 & .0010 & .0150 & .0075 \\
\hline time * Subject & 28 & 2609.508 & 93.197 & & & & \\
\hline Trial * time & 4 & 1168.766 & 292.192 & 4.898 & .0040 & .0197 & .0073 \\
\hline Trial * time ${ }^{*} \mathrm{~S} . .$. & 28 & 1670.232 & 59.651 & & & & \\
\hline
\end{tabular}

Dependent: CHO oxidation ( $\mu \mathrm{mol} / \mathrm{kg} / \mathrm{min})$

\section{Means Table}

Effect: Trial

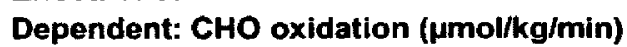

\begin{tabular}{|c|c|c|c|c|}
\hline & Count & Mean & Std. Dev. & Std. Error \\
\hline with & 40 & 109.469 & 32.167 & 5.086 \\
\hline without & 40 & 115.279 & 31.943 & 5.051 \\
\hline
\end{tabular}

\section{Means Table}

Effect: time

Dependent: CHO oxidation ( $\mu \mathrm{mol} / \mathrm{kg} / \mathrm{min}$ )

\begin{tabular}{l|r|r|r|r|}
\multicolumn{1}{c}{ Count } & \multicolumn{2}{c}{ Mean } & Std. Dev. & Std. Error \\
\cline { 2 - 5 } $5 \min$ & 16 & 122.226 & 36.524 & 9.131 \\
\cline { 2 - 5 } $15 \min$ & 16 & 112.317 & 32.791 & 8.198 \\
\cline { 2 - 5 } $25 \min$ & 16 & 112.409 & 28.855 & 7.214 \\
\cline { 2 - 5 } $35 \min$ & 16 & 108.224 & 32.575 & 8.144 \\
\cline { 2 - 5 } $45 \min$ & 16 & 106.693 & 30.475 & 7.619 \\
\hline
\end{tabular}

Means Table

Effect: Trial " time

Dependent: CHO oxidation ( $\mu \mathrm{mol} / \mathrm{kg} / \mathrm{min}$ )

with, 5 min

with, $15 \mathrm{~min}$

with, $25 \mathrm{~min}$

with, $35 \mathrm{~min}$

with, 45 min

without, $5 \mathrm{~min}$

without, $15 \mathrm{~min}$

without, $25 \mathrm{~min}$

without, 35 min

without, $45 \mathrm{~min}$

\begin{tabular}{|r|r|r|r|}
\multicolumn{1}{r|}{ Count } & \multicolumn{1}{c}{ Mean } & Std. Dev. & Std. Error \\
\hline 8 & 112.734 & 36.565 & 12.928 \\
\hline 8 & 110.625 & 32.484 & 11.485 \\
\hline 8 & 108.352 & 30.029 & 10.617 \\
\hline 8 & 110.251 & 36.643 & 12.955 \\
\hline 8 & 105.382 & 33.063 & 11.689 \\
\hline 8 & 131.717 & 36.271 & 12.824 \\
\hline 8 & 114.010 & 35.247 & 12.462 \\
\hline 8 & 116.465 & 29.065 & 10.276 \\
\hline 8 & 106.197 & 30.361 & 10.734 \\
\hline 8 & 108.004 & 29.885 & 10.566 \\
\hline
\end{tabular}




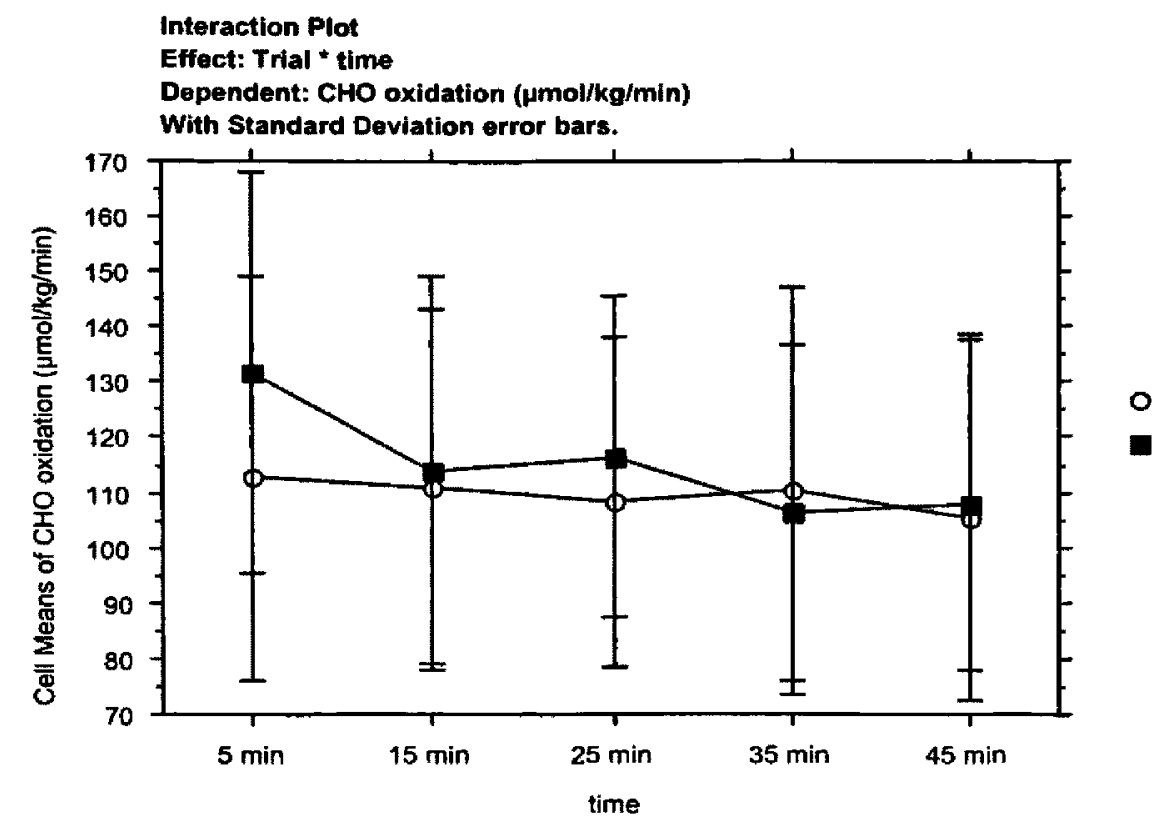

Comparison 1

Effect: Trial * Time

\begin{tabular}{|l|r|}
\hline With min 5 vs. Without min 5 \\
\hline df & 1 \\
\hline Sum of squares & 1 \\
\hline Mean square & 1441.531 \\
\hline F-Value & 24.166 \\
\hline P-Value & .0001 \\
\hline G-G & .0009 \\
\hline H-F & .0001 \\
\hline
\end{tabular}

Comparison 3

Effect: Trial $*$ Time

\begin{tabular}{|l|r|}
\hline With min 25 vs. Without $\min 25$ \\
\hline df & 1 \\
\hline Sum of squares & 263.251 \\
\hline Mean square & 263.251 \\
\hline F-Value & 4.413 \\
\hline P-Value & .0448 \\
\hline G-G & .0676 \\
\hline H-F & .0527 \\
\hline
\end{tabular}

Comparison 2

Effect: Trial * Time

\begin{tabular}{|l|r|}
\hline \multicolumn{2}{|l|}{ With min 15 vs. Without min 15 } \\
\hline df & 1 \\
\hline Sum of squares & 45.833 \\
\hline Mean square & 45.833 \\
\hline F-Value & .768 \\
\hline P-Value & .3882 \\
\hline G-G & .3194 \\
\hline H-F & .3666 \\
\hline
\end{tabular}

\begin{tabular}{|l|r|}
\hline \multicolumn{2}{|l|}{ With min 35 vs. Without $\min 35$} \\
\hline df & 1 \\
\hline Sum of squares & 65.732 \\
\hline Mean square & 65.732 \\
\hline F-Value & 1.102 \\
\hline P-Value & .3028 \\
\hline G-G & .2614 \\
\hline H-F & .2907 \\
\hline
\end{tabular}


Comparison 5

Effect: Trial * Time

\begin{tabular}{|l|r|}
\hline With min 45 vs. Without min45 \\
\hline df & 1 \\
\hline Sum of squares & 27.484 \\
\hline Mean square & 27.484 \\
\hline F-Value & .461 \\
\hline P-Value & .5028 \\
\hline G-G & .3992 \\
\hline H-F & .4695 \\
\hline
\end{tabular}

Comparison 7

Effect: Trial * Time

\begin{tabular}{|l|r|}
\hline \multicolumn{2}{|l|}{ With min 5 vs. With $\min 45$} \\
\hline df & 1 \\
\hline Sum of squares & 216.164 \\
\hline Mean square & 216.164 \\
\hline F-Value & .3624 \\
\hline P-Value & .0673 \\
\hline G-G & .0887 \\
\hline H-F & .0753 \\
\hline
\end{tabular}

\section{Comparison 6}

Effect: Trial * Time

\begin{tabular}{|l|r|}
\hline \multicolumn{2}{|l|}{ With min 5 vs. With $\min 25$} \\
\hline df & 1 \\
\hline Sum of squares & 76.781 \\
\hline Mean square & 76.781 \\
\hline F-Value & 1.287 \\
\hline P-Value & .2662 \\
\hline G-G & .2364 \\
\hline H-F & .2581 \\
\hline
\end{tabular}

\section{Comparison 9}

Effect: Trial * Time

\begin{tabular}{|l|r|}
\hline \multicolumn{2}{|l|}{ Without min 5 vs. Without min 45 } \\
\hline df & 1 \\
\hline Sum of squares & 2249.368 \\
\hline Mean square & 2249.368 \\
\hline F-Value & 37.709 \\
\hline P-Value & .0001 \\
\hline G-G & .0001 \\
\hline H-F & .0001 \\
\hline
\end{tabular}

\begin{tabular}{|l|r|}
\hline Without min 5 vs. Without min 25 \\
\hline df & 1 \\
\hline Sum of squares & 930.555 \\
\hline Mean square & 930.555 \\
\hline F-Value & 15.600 \\
\hline P-Value & .0005 \\
\hline G-G & .0040 \\
\hline H-F & .0011 \\
\hline
\end{tabular}

Comparison 8

Effect: Trial * Time 


\section{Group 1 RPE}

Type III Sums of Squares

\begin{tabular}{|c|c|c|c|c|c|c|c|}
\hline Source & df & Sum of Squares & Mean Square & F-Value & P-Value & G-G & $\mathrm{H}-\mathrm{F}$ \\
\hline Subject & 7 & 108.972 & 15.567 & & & & \\
\hline Trial & 1 & 4.753 & 4.753 & 2.838 & .1359 & .1359 & .1359 \\
\hline Trial * Subject & 7 & 11.722 & 1.675 & & & & \\
\hline time & 4 & 97.831 & 24.458 & 11.574 & .0001 & .0083 & .0071 \\
\hline time * Subject & 28 & 59.169 & 2.113 & & & & \\
\hline Trial * time & 4 & .981 & .245 & .867 & .4956 & .4415 & .4682 \\
\hline Trial * time * $\mathbf{S}$ & 28 & 7.919 & .283 & & & & \\
\hline
\end{tabular}

Dependent: RPE

\section{Means Table}

Effect: Trial

Dependent: RPE

\begin{tabular}{|c|c|c|c|c|}
\hline & Count & Mean & Std. Dev. & Std. Error \\
\hline with & 40 & 12.962 & 1.766 & .279 \\
\hline without & 40 & 13.450 & 2.056 & .325 \\
\hline
\end{tabular}

\section{Means Table}

Effect: time

Dependent: RPE

\begin{tabular}{l|r|r|r|r|}
\multicolumn{1}{c}{ Count } & \multicolumn{2}{c}{ Mean } & Std. Dev. & Std. Error \\
\cline { 2 - 5 } $5 \min$ & 16 & 11.344 & 1.207 & .302 \\
\cline { 2 - 5 } $15 \min$ & 16 & 12.750 & 1.342 & .335 \\
\cline { 2 - 5 } $25 \min$ & 16 & 13.344 & 1.546 & .387 \\
\cline { 2 - 5 } $35 \min$ & 16 & 14.156 & 1.767 & .442 \\
\hline $45 \min$ & 16 & 14.438 & 2.032 & .508 \\
\hline
\end{tabular}

\section{Means Table \\ Effect: Trial * time \\ Dependent: RPE}

with, $5 \mathrm{~min}$
with, $15 \mathrm{~min}$
with, $25 \mathrm{~min}$
with, $35 \mathrm{~min}$
with, $45 \mathrm{~min}$
without, $5 \mathrm{~min}$
without, $15 \mathrm{~min}$
without, $25 \mathrm{~min}$
without, $35 \mathrm{~min}$
without, $45 \mathrm{~min}$

\begin{tabular}{|c|c|c|c|}
\hline Count & Mean & Std. Dev. & Std. Error \\
\hline 8 & 11.250 & 1.309 & .463 \\
\hline 8 & 12.500 & 1.195 & .423 \\
\hline 8 & 12.938 & 1.208 & .427 \\
\hline 8 & 14.000 & 1.690 & .598 \\
\hline 8 & 14.125 & 1.885 & .666 \\
\hline 8 & 11.438 & 1.178 & .417 \\
\hline 8 & 13.000 & 1.512 & .535 \\
\hline 8 & 13.750 & 1.813 & .641 \\
\hline 8 & 14.312 & 1.945 & .688 \\
\hline 8 & 14.750 & 2.252 & .796 \\
\hline
\end{tabular}




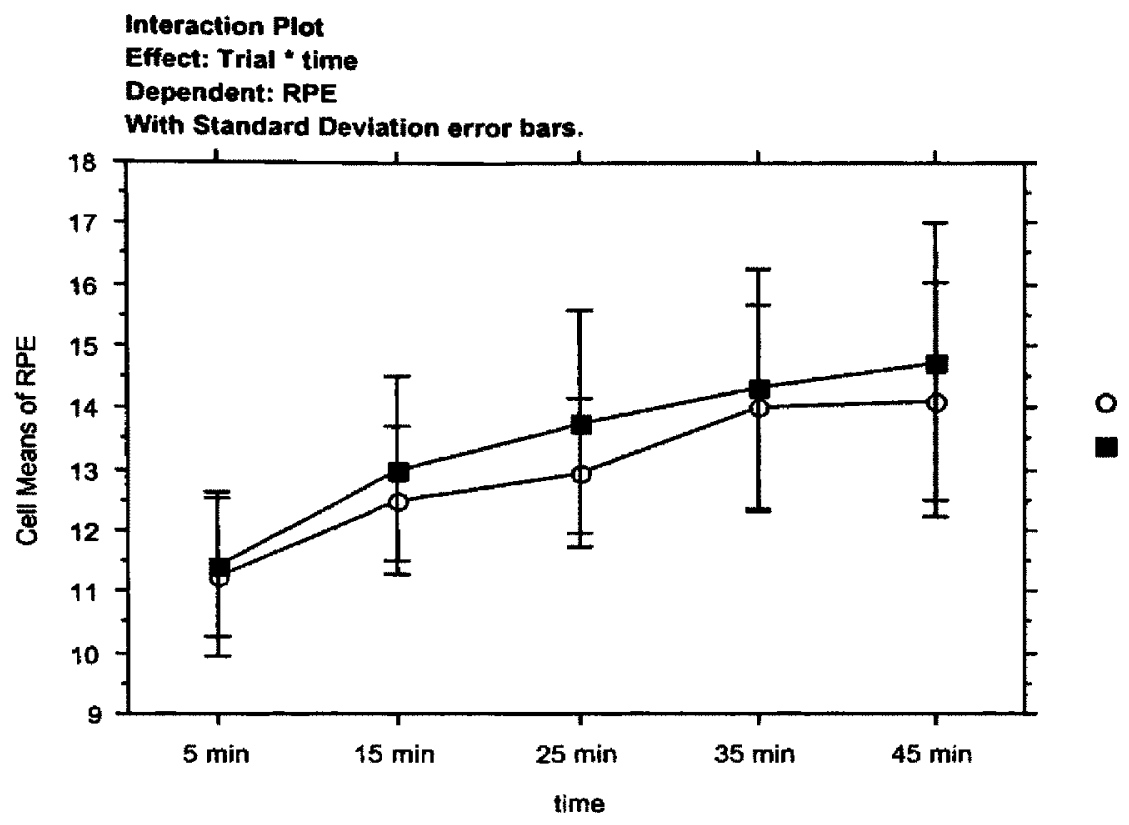

Comparison 1

Effect: Trial * Time

\begin{tabular}{|l|r|}
\hline With $\min 5$ vs. Without $\min 5$ \\
\hline df & 1 \\
\hline Sum of squares & .141 \\
\hline Mean square & .141 \\
\hline F-Value & .497 \\
\hline P-Value & .4865 \\
\hline G-G & .3698 \\
\hline H-F & .4253 \\
\hline
\end{tabular}

Comparison 3

Effect: Trial * Time

\begin{tabular}{|l|r|}
\hline With min 25 vs. Without min 25 \\
\hline df & 1 \\
\hline Sum of squares & 2.641 \\
\hline Mean square & 2.641 \\
\hline F-Value & 9.337 \\
\hline P-Value & .0049 \\
\hline G-G & .0194 \\
\hline H-F & .0112 \\
\hline
\end{tabular}

Comparison 2 Effect: Trial * Time

\begin{tabular}{|l|r|}
\hline With min 15 vs. Without $\min 15$ \\
\hline df & 1 \\
\hline Sum of squares & 1.000 \\
\hline Mean square & 1.000 \\
\hline F-Value & 3.536 \\
\hline P-Value & .0805 \\
\hline G-G & .0940 \\
\hline H-F & .0848 \\
\hline
\end{tabular}

Comparison 4 Effect: Trial * Time

\begin{tabular}{|l|r|}
\hline With min 35 vs. Without min 35 \\
\hline df & 1 \\
\hline Sum of squares & .391 \\
\hline Mean square & .391 \\
\hline F-Value & 1.381 \\
\hline P-Value & .2498 \\
\hline G-G & .2193 \\
\hline H-F & .2362 \\
\hline
\end{tabular}




\section{Comparison 5}

Effect: Trial * Time

\begin{tabular}{|l|r|}
\hline With min 45 vs. Without min45 \\
\hline df & 1 \\
\hline Sum of squares & 1.562 \\
\hline Mean square & 1.562 \\
\hline F-Value & 5.525 \\
\hline P-Value & .0260 \\
\hline G-G & .0511 \\
\hline H-F & .0393 \\
\hline
\end{tabular}

Comparison 7

Effect: Trial * Time

\begin{tabular}{|l|r|}
\hline \multicolumn{2}{|l|}{ With min 5 vs. With min 45 } \\
\hline df & 1 \\
\hline Sum of squares & 33.063 \\
\hline Mean square & 33.063 \\
\hline F-Value & 116.906 \\
\hline P-Value & .0001 \\
\hline G-G & .0001 \\
\hline H-F & .0001 \\
\hline
\end{tabular}

Comparison 6

Effect: Trial * Time

\begin{tabular}{|l|r|}
\hline \multicolumn{2}{|l|}{ With min 5 vs. With $\min 25$} \\
\hline df & 1 \\
\hline Sum of squares & 11.391 \\
\hline Mean square & 11.391 \\
\hline F-Value & 40.276 \\
\hline P-Value & .0001 \\
\hline G-G & .0002 \\
\hline H-F & .0001 \\
\hline
\end{tabular}

\section{Comparison 8}

Effect: Trial * Time

\begin{tabular}{|l|r|}
\hline Without min 5 vs. Without min 25 \\
\hline df & 1 \\
\hline Sum of squares & 21.391 \\
\hline Mean square & 21.391 \\
\hline F-Value & 75.635 \\
\hline P-Value & .0001 \\
\hline G-G & .0001 \\
\hline H-F & .0001 \\
\hline
\end{tabular}

\section{Comparison 9}

Effect: Trial * Time

\begin{tabular}{|l|r|}
\hline \multicolumn{2}{|l|}{ Without min 5 vs. Without min 45 } \\
\hline df & 1 \\
\hline Sum of squares & 43.891 \\
\hline Mean square & 43.891 \\
\hline F-Value & 155.193 \\
\hline P-Value & .0001 \\
\hline G-G & .0001 \\
\hline H-F & .0001 \\
\hline
\end{tabular}




\section{Group 1 Lactate}

Type III Sums of Squares

\begin{tabular}{|c|c|c|c|c|c|c|c|}
\hline Source & df & Sum of Squares & Mean Square & F-Value & P.Value & G-G & $\mathrm{H}-\mathrm{F}$ \\
\hline Subject & 7 & 123.741 & 17.677 & & & & \\
\hline Trial & 1 & 5.980 & 5.980 & 1.974 & .2029 & .2029 & .2029 \\
\hline Trial * Subject & 7 & 21.209 & 3.030 & & & & \\
\hline time & 4 & 32.022 & 8.005 & 6.590 & .0007 & .0180 & .0113 \\
\hline time "Subject & 28 & 34.015 & 1.215 & & & & \\
\hline Trial * time & 4 & 4.283 & 1.071 & 1.594 & .2034 & .2399 & .2292 \\
\hline Trial * time $* S \ldots$ & 28 & 18.804 & .672 & & & & \\
\hline
\end{tabular}

Dependent: lactate (mM)

\section{Means Table}

Effect: Trial

Dependent: lactate (mM)

\begin{tabular}{|c|c|c|c|c|}
\hline & Count & Mean & Std. Dev. & Std. Error \\
\hline with & 40 & 3.407 & 1.287 & .204 \\
\hline without & 40 & 3.954 & 2.084 & .330 \\
\hline
\end{tabular}

\section{Means Table}

Effect: time

Dependent: lactate (mM)

\begin{tabular}{l|r|r|r|r|}
\multicolumn{1}{c}{ Count } & \multicolumn{2}{c}{ Mean } & Std. Dev. & \multicolumn{1}{c|}{ Std. Error } \\
\cline { 2 - 5 } $0 \mathrm{~min}$ & 16 & 2.493 & 1.023 & .256 \\
\hline $15 \mathrm{~min}$ & 16 & 3.852 & 1.380 & .345 \\
\hline $16 \mathrm{~min}$ & 3.744 & 1.310 & .327 \\
\cline { 2 - 5 } $35 \mathrm{~min}$ & 16 & 4.385 & 1.948 & .487 \\
\cline { 2 - 5 } $45 \mathrm{~min}$ & 16 & 3.929 & 2.325 & .581 \\
\cline { 2 - 5 }
\end{tabular}

\section{Means Table}

Effect: Trial * time

Dependent: lactate (mM)

\begin{tabular}{l|r|r|r|r|}
\multicolumn{1}{c}{ Count } & \multicolumn{1}{c}{ Mean } & Std. Dev. & Std. Error \\
\cline { 2 - 5 } with, 0 min & 8 & 2.420 & .887 & .313 \\
with, 15 min & 8 & 3.650 & 1.145 & .405 \\
with, 25 min & 8 & 3.697 & 1.186 & .419 \\
with, 35 min & 8 & 4.015 & 1.663 & .588 \\
with, 45 min & 8 & 3.253 & 1.111 & .393 \\
without, 0 min & 8 & 2.565 & 1.202 & .425 \\
without, 15 min & 8 & 4.054 & 1.636 & .578 \\
without, $25 \mathrm{~min}$ & 8 & 3.791 & 1.505 & .532 \\
without, 35 min & 8 & 4.754 & 2.249 & .795 \\
without, $45 \mathrm{~min}$ & 8 & 4.605 & 3.050 & 1.078 \\
\hline
\end{tabular}




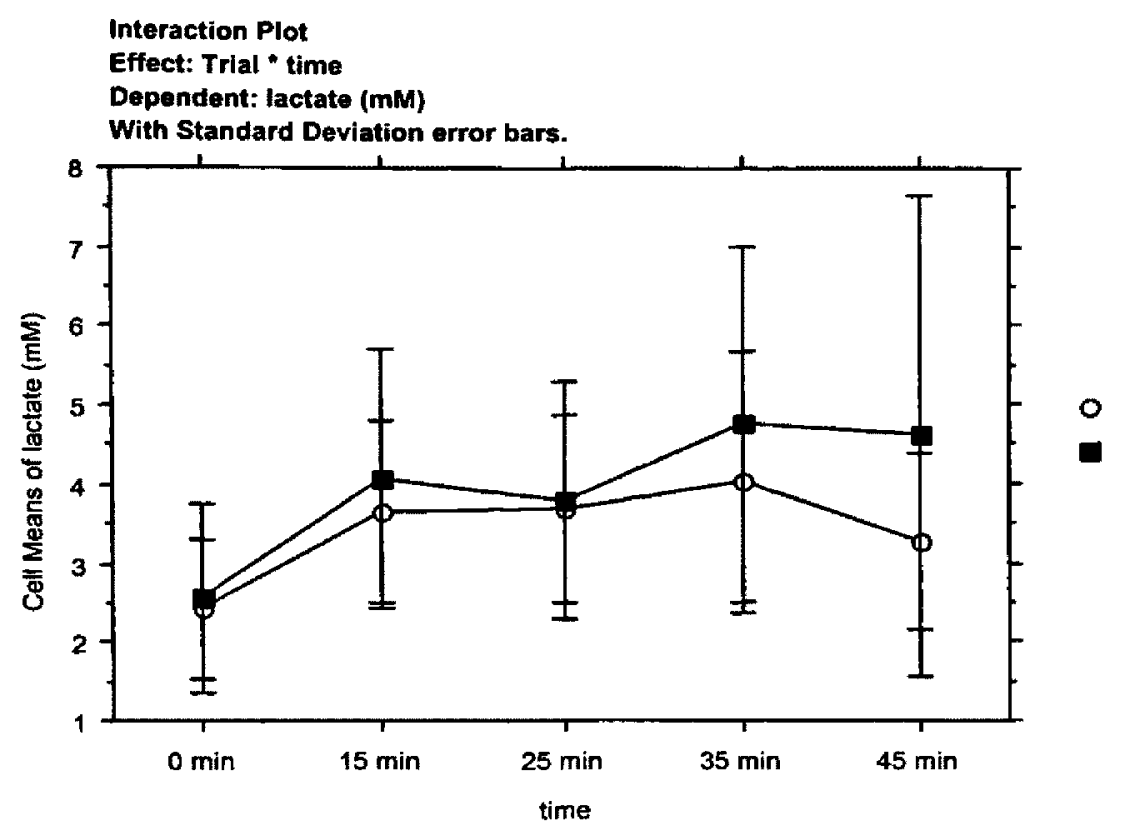

Comparison 1

Effect: Trial * Time

\begin{tabular}{|l|r|}
\hline \multicolumn{2}{|l|}{ With min 5 vs. Without min 5 } \\
\hline df & 1 \\
\hline Sum of squares & .084 \\
\hline Mean square & .084 \\
\hline F-Value & .125 \\
\hline P-Value & .7259 \\
\hline G-G & .5268 \\
\hline H-F & .6044 \\
\hline
\end{tabular}

Comparison 2

Effect: Trial * Time

\begin{tabular}{|l|r|}
\hline \multicolumn{2}{|l|}{ With min 15 vs. Without $\min 15$} \\
\hline df & 1 \\
\hline Sum of squares & .655 \\
\hline Mean square & .655 \\
\hline F-Value & .975 \\
\hline P-Value & .3319 \\
\hline G-G & .2645 \\
\hline H-F & .2917 \\
\hline
\end{tabular}

Comparison 3

Effect: Trial ${ }^{*}$ Time

\begin{tabular}{|l|r|}
\hline With min 25 vs. Without min 25 \\
\hline df & 1 \\
\hline Sum of squares & .035 \\
\hline Mean square & .035 \\
\hline F-Value & .053 \\
\hline P-Value & .8200 \\
\hline G-G & .6120 \\
\hline H-F & .6969 \\
\hline
\end{tabular}

Comparison 4

Effect: Trial $*$ Time

\begin{tabular}{|l|r|}
\hline \multicolumn{2}{|l|}{ With min 35 vs. Without $\min 35$} \\
\hline df & 1 \\
\hline Sum of squares & 2.183 \\
\hline Mean square & 2.183 \\
\hline F-Value & 3.251 \\
\hline P-Value & .0822 \\
\hline G-G & .1046 \\
\hline H-F & .0988 \\
\hline
\end{tabular}


Comparison 5

Effect: Trial $*$ Time

\begin{tabular}{|l|r|}
\hline \multicolumn{2}{|l|}{ With min 45 vs. Without min45 } \\
\hline df & 1 \\
\hline Sum of squares & 7.305 \\
\hline Mean square & 7.305 \\
\hline F-Value & 10.877 \\
\hline P-Value & .0027 \\
\hline G-G & .0154 \\
\hline H-F & .0090 \\
\hline
\end{tabular}

Comparison 7

Effect: Trial * Time

\begin{tabular}{|l|r|}
\hline \multicolumn{2}{|l|}{ With min 5 vs. With min 45 } \\
\hline df & 1 \\
\hline Sum of squares & 2.775 \\
\hline Mean square & 2.775 \\
\hline$\overline{\text { F-Value }}$ & 4.132 \\
\hline P-Value & .0517 \\
\hline G-G & .0792 \\
\hline H-F & .0705 \\
\hline
\end{tabular}

Comparison 6

Effect: Trial * Time

\begin{tabular}{|l|r|}
\hline \multicolumn{2}{|l|}{ With min 5 vs. With $\min 25$} \\
\hline df & 1 \\
\hline Sum of squares & 6.520 \\
\hline Mean square & 6.520 \\
\hline F-Value & 9.709 \\
\hline P-Value & .0042 \\
\hline G-G & .0196 \\
\hline H-F & .0123 \\
\hline
\end{tabular}

Comparison 8 Effect: Trial * Time

\begin{tabular}{|l|r|}
\hline \multicolumn{2}{|l|}{ Without min 5 vs. Without $\min 25$} \\
\hline $\mathrm{df}$ & 1 \\
\hline Sum of squares & 6.040 \\
\hline Mean square & 6.010 \\
\hline F-Value & 8.949 \\
\hline P-Value & .0057 \\
\hline G-G & .0232 \\
\hline H-F & .0152 \\
\hline
\end{tabular}

Comparison 9

Effect: Trial * Time

\begin{tabular}{|l|r|}
\hline Without min 5 vs. Without $\min 45$ \\
\hline df & 1 \\
\hline Sum of squares & 16.632 \\
\hline Mean square & 16.632 \\
\hline F-Value & 24.766 \\
\hline P-Value & .0001 \\
\hline G-G & .0016 \\
\hline H-F & .0005 \\
\hline
\end{tabular}




\section{Group 1 Temperature}

\section{Type III Sums of Squares}

\begin{tabular}{|c|c|c|c|c|c|c|c|}
\hline Source & $d t$ & Sum of Squares & Mean Square & F-Value & P-Value & G-G & $\mathrm{H}-\mathrm{F}$ \\
\hline Subject & 7 & 21.218 & 3.031 & & & & \\
\hline trial & 1 & .047 & .047 & .129 & .7299 & .7299 & .7299 \\
\hline trial - Subject & 7 & 2.529 & .361 & & & & \\
\hline time & 6 & 11.902 & 1.984 & 8.890 & .0001 & 0108 & .0074 \\
\hline time "Subject & 42 & 9.372 & .223 & & & & \\
\hline trial * time & 6 & .093 & .015 & 1.254 & .2990 & .3152 & .3162 \\
\hline trial * time * $\mathbf{S} .$. & 42 & .517 & .012 & & & & \\
\hline
\end{tabular}

Dependent: rectal temp

\section{Means Table}

Effect: trial

\section{Dependent: rectal temp}

\begin{tabular}{|c|c|c|c|c|}
\hline & Count & Mean & Std. Dev. & Std. Error \\
\hline with & 56 & 37.549 & .634 & .085 \\
\hline without & 56 & 37.589 & .654 & .087 \\
\hline
\end{tabular}

\section{Means Table}

Effect: time

Dependent: rectal temp

\begin{tabular}{|c|c|c|c|c|}
\hline & Count & Mean & Std. Dev. & Std. Error \\
\hline 0 & 16 & 37.065 & .564 & .141 \\
\hline 5 & 16 & 37.163 & .496 & .124 \\
\hline 15 & 16 & 37.479 & .425 & .106 \\
\hline 25 & 16 & 37.703 & .437 & .109 \\
\hline 35 & 16 & 37.878 & .434 & .109 \\
\hline 45 & 16 & 38.001 & .457 & .114 \\
\hline $10 \mathrm{~min}$ post & 16 & 37.694 & .958 & .240 \\
\hline
\end{tabular}

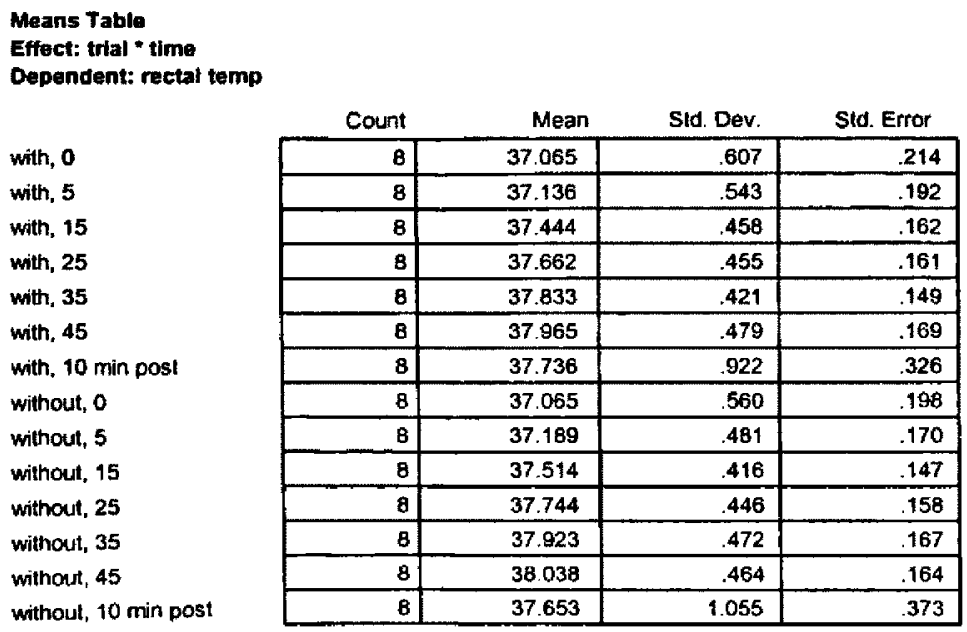




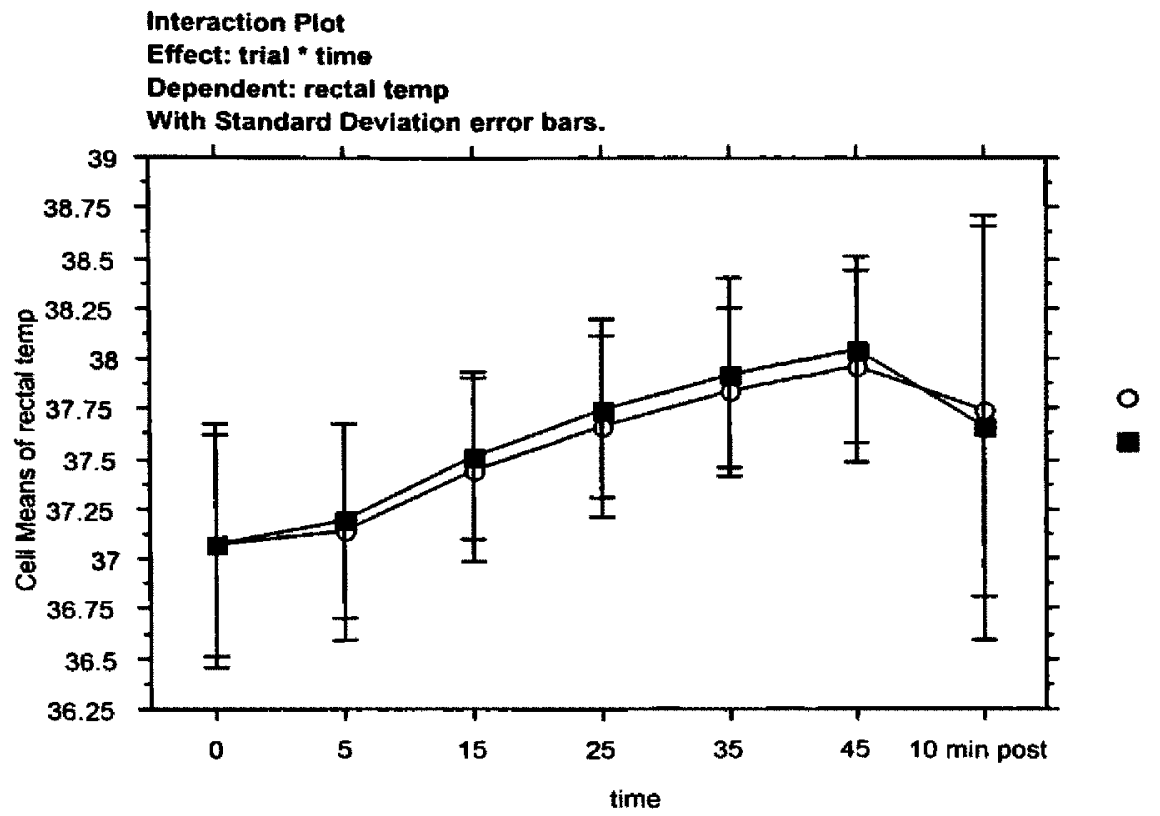

Comparison 1

Effect: Trial * Time

\begin{tabular}{|l|r|}
\hline With min 0 vs. Without min 0 \\
\hline df & 1 \\
\hline Sum of squares & $-4.44 \mathrm{E}-16$ \\
\hline Mean square & $-4.44 \mathrm{E}-16$ \\
\hline F-Value & $-3.60 \mathrm{E}-14$ \\
\hline P-Value & 1.0000 \\
\hline G-G & $*$ \\
\hline H-F & $*$ \\
\hline
\end{tabular}

Comparison 3

Effect: Trial * Time

\begin{tabular}{|l|r|}
\hline \multicolumn{2}{|l|}{ With min 15 vs. Without min 15 } \\
\hline df & 1 \\
\hline Sum of squares & .020 \\
\hline Mean square & .020 \\
\hline F-Value & 1.614 \\
\hline P-Value & .2109 \\
\hline G-G & .1723 \\
\hline H-F & .1877 \\
\hline
\end{tabular}

Comparison 2

Effect: Trial * Time

\begin{tabular}{|l|r|}
\hline \multicolumn{2}{|l|}{ With min 5 vs. Without $\min 5$} \\
\hline df & 1 \\
\hline Sum of squares & .011 \\
\hline Mean square & .011 \\
\hline F-Value & .912 \\
\hline P-Value & .3450 \\
\hline G-G & .2342 \\
\hline H-F & .2661 \\
\hline
\end{tabular}

Comparison 4

Effect: Trial * Time

\begin{tabular}{|l|r|}
\hline \multicolumn{2}{|l|}{ With $\min 25$ vs. Without $\min 25$} \\
\hline df & 1 \\
\hline Sum of squares & .027 \\
\hline Mean square & .027 \\
\hline F-Value & 2.183 \\
\hline P-Value & .1470 \\
\hline G-G & .1406 \\
\hline H-F & .1481 \\
\hline
\end{tabular}


Comparison 5

Effect: Trial * Time

\begin{tabular}{|l|r|}
\hline With min 35 vs. Without min35 \\
\hline df & 1 \\
\hline Sum of squares & .032 \\
\hline Mean square & .032 \\
\hline F-Value & 2.601 \\
\hline P-Value & .1143 \\
\hline G-G & .1230 \\
\hline H-F & .1264 \\
\hline
\end{tabular}

Comparison 7

Effect: Trial * Time

\begin{tabular}{|l|r|}
\hline With 10 post vs. Without 10 post \\
\hline df & 1 \\
\hline Sum of squares & .028 \\
\hline Mean square & .028 \\
\hline F-Value & 2.237 \\
\hline P-Value & .1422 \\
\hline G-G & .1381 \\
\hline H-F & .1450 \\
\hline
\end{tabular}

Comparison 9

Effect: Trial * Time

\begin{tabular}{|l|r|}
\hline \multicolumn{2}{|l|}{ With min 0 vs. With $\min 45$} \\
\hline df & 1 \\
\hline Sum of squares & 3.240 \\
\hline Mean square & 3.240 \\
\hline F-Value & 263.026 \\
\hline P-Value & .0001 \\
\hline G-G & .0001 \\
\hline H-F & .0001 \\
\hline
\end{tabular}

Comparison 6

Effect: Trial * Time

\begin{tabular}{|l|r|}
\hline \multicolumn{2}{|l|}{ With min 45 vs. Without $\min 45$} \\
\hline df & 1 \\
\hline Sum of squares & .022 \\
\hline Mean square & .022 \\
\hline F-Value & 1.766 \\
\hline P-Value & .1910 \\
\hline G-G & .1627 \\
\hline H-F & .1757 \\
\hline
\end{tabular}

\section{Comparison 8}

Effect: Trial * Time

\begin{tabular}{|l|r|}
\hline \multicolumn{2}{|l|}{ With min 0 vs. With $\min 25$} \\
\hline df & 1 \\
\hline Sum of squares & 1.430 \\
\hline Mean square & 1.430 \\
\hline F-Value & 116.090 \\
\hline P-Value & .0001 \\
\hline G-G & .0001 \\
\hline H-F & .0001 \\
\hline
\end{tabular}

\section{Comparison 10 \\ Effect: Trial * Time}

\begin{tabular}{|l|r|}
\hline With min 45 vs. With 10 post \\
\hline df & 1 \\
\hline Sum of squares & .210 \\
\hline Mean square & .210 \\
\hline F-Value & 17.041 \\
\hline P-Value & .0002 \\
\hline G-G & .0079 \\
\hline H-F & .0040 \\
\hline
\end{tabular}


Comparison 11

Effect: Trial * Time

\begin{tabular}{|l|r|}
\hline \multicolumn{2}{|l|}{ Without min 0 vs. Without $\min 25$} \\
\hline df & 1 \\
\hline Sum of squares & 1.849 \\
\hline Mean square & 1.849 \\
\hline F-Value & 150.115 \\
\hline P-Value & .0001 \\
\hline G-G & .0001 \\
\hline H-F & .0001 \\
\hline
\end{tabular}

Comparison 12

Effect: Trial * Time

\begin{tabular}{|l|r|}
\hline Without min 0 vs. Without $\min 45$ \\
\hline $\mathrm{df}$ & 1 \\
\hline Sum of squares & 3.793 \\
\hline Mean square & 3.793 \\
\hline F-Value & 307.899 \\
\hline P-Value & .0001 \\
\hline G-G & .0001 \\
\hline H-F & .0001 \\
\hline
\end{tabular}

\section{Comparison 13}

\section{Effect: Trial * Time}

\begin{tabular}{|l|r|}
\hline Without min 45 vs. Without 10 post \\
\hline df & 1 \\
\hline Sum of squares & .595 \\
\hline Mean square & .595 \\
\hline F-Value & 48.341 \\
\hline P-Value & .0001 \\
\hline G-G & .0003 \\
\hline H-F & .0001 \\
\hline
\end{tabular}




\section{Group 2 RER}

Type III Sums of Squares

\begin{tabular}{|c|c|c|c|c|c|c|c|}
\hline Source & df & Sum of Squares & Mean Square & F-Value & P-Value & G-G & $\mathrm{H}-\mathrm{F}$ \\
\hline Subject & 7 & .026 & .004 & & & & \\
\hline Trial & 1 & .005 & .005 & 3.090 & .1222 & .1222 & .1222 \\
\hline Trial * Subject & 7 & .011 & .002 & & & & \\
\hline time & 4 & .007 & .002 & 3.366 & .0227 & .0808 & .0663 \\
\hline time Subject & 28 & .014 & .001 & & & & \\
\hline Trial * time & 4 & .002 & 4.146E-4 & 4.830 & .0043 & .0169 & .0048 \\
\hline Trial * time * S. & 28 & .002 & $8.583 E-5$ & & & & \\
\hline
\end{tabular}

Dependent: RER

\section{Means Table}

Effect: Trial

Dependent: RER

\begin{tabular}{|c|c|c|c|c|}
\hline & Count & Mean & Std. Dev. & Std. Error \\
\hline with & 40 & .894 & .030 & .005 \\
\hline without & 40 & .910 & .026 & .004 \\
\hline
\end{tabular}

\section{Means Table}

Effect: time

Dependent: RER

\begin{tabular}{|c|c|c|c|c|}
\hline & Count & Mean & Std. Dev. & Std. Error \\
\hline $5 \mathrm{~min}$ & 16 & .918 & .045 & .011 \\
\hline $15 \mathrm{~min}$ & 16 & .905 & .021 & .005 \\
\hline $25 \mathrm{~min}$ & 16 & .897 & .022 & .006 \\
\hline $35 \mathrm{~min}$ & 16 & .900 & .020 & .005 \\
\hline $45 \mathrm{~min}$ & 16 & .890 & .025 & .006 \\
\hline
\end{tabular}

\section{Means Table}

Effect: Trial * time

Dependent: RER

with. $5 \mathrm{~min}$

with, $15 \mathrm{~min}$

with, $25 \mathrm{~min}$

with, $35 \mathrm{~min}$

with, $45 \mathrm{~min}$

without, $5 \mathrm{~min}$

without, $15 \mathrm{~min}$

without, $25 \mathrm{~min}$

without, $35 \mathrm{~min}$

without, $45 \mathrm{~min}$

\begin{tabular}{|c|c|c|c|}
\hline Count & Mean & Std. Dev. & Std. Error \\
\hline 8 & .903 & .044 & .015 \\
\hline 8 & .898 & .024 & .009 \\
\hline 8 & .892 & .029 & .010 \\
\hline 8 & 899 & .023 & .008 \\
\hline 8 & .879 & .027 & .010 \\
\hline 8 & .932 & .045 & .016 \\
\hline 8 & .912 & .016 & .006 \\
\hline 8 & .902 & .013 & .005 \\
\hline 8 & .901 & .018 & .006 \\
\hline 8 & .901 & .018 & .006 \\
\hline
\end{tabular}




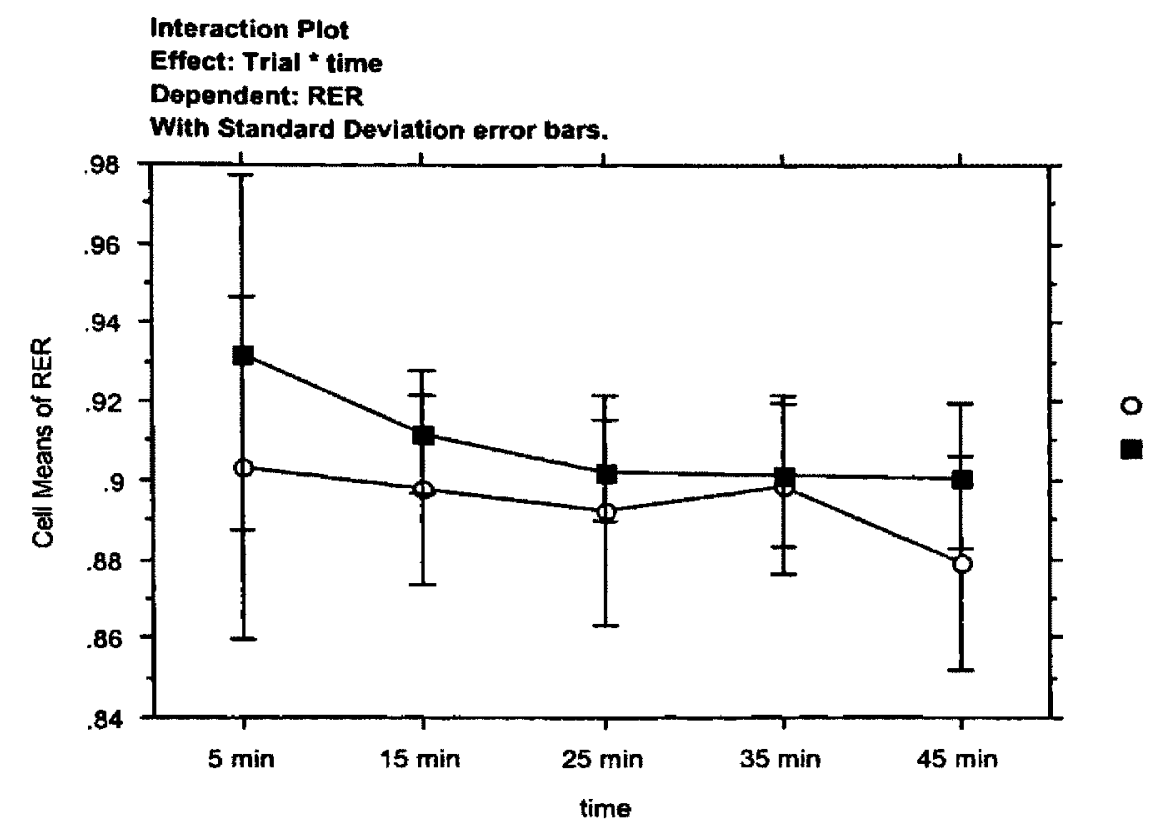

Comparison 1

Effect: Trial * Time

\begin{tabular}{|l|r|}
\hline \multicolumn{2}{|l|}{ With min 5 vs. Without min 5 } \\
\hline df & 1 \\
\hline Sum of squares & .003 \\
\hline Mean square & .003 \\
\hline F-Value & 39.005 \\
\hline P-Value & .0001 \\
\hline G-G & .0001 \\
\hline H-F & .0001 \\
\hline
\end{tabular}

Comparison 3

Effect: Trial * Time

\begin{tabular}{|l|r|}
\hline \multicolumn{2}{|l|}{ With $\min 25$ vs. Without $\min 25$} \\
\hline df & 1 \\
\hline Sum of squares & $3.926 \mathrm{E}-4$ \\
\hline Mean square & $3.926 \mathrm{E}-4$ \\
\hline F-Value & 4.574 \\
\hline P-Value & .0413 \\
\hline G-G & .0609 \\
\hline H-F & .0427 \\
\hline
\end{tabular}

Comparison 2

Effect: Trial * Time

\begin{tabular}{|l|r|}
\hline \multicolumn{2}{|l|}{ With min 15 vs. Without $\min 15$} \\
\hline df & 1 \\
\hline Sum of squares & .001 \\
\hline Mean square & .001 \\
\hline F-Value & 9.439 \\
\hline P-Value & .0047 \\
\hline G-G & .0138 \\
\hline H-F & .0051 \\
\hline
\end{tabular}


Comparison 5

Effect: Trial * Time

\begin{tabular}{|l|r|}
\hline \multicolumn{2}{|l|}{ With min 45 vs. Without min45 } \\
\hline df & 1 \\
\hline Sum of squares & .002 \\
\hline Mean square & .002 \\
\hline F-Value & 21.968 \\
\hline P-Value & .0001 \\
\hline G-G & .0009 \\
\hline H-F & .0001 \\
\hline
\end{tabular}

Comparison 7

Effect: Trial * Time

\begin{tabular}{|l|r|}
\hline \multicolumn{2}{|l|}{ With $\min 5$ vs. With $\min 45$} \\
\hline df & 1 \\
\hline Sum of squares & .002 \\
\hline Mean square & .002 \\
\hline F-Value & 27.402 \\
\hline P-Value & .0001 \\
\hline G-G & .0003 \\
\hline H-F & .0001 \\
\hline
\end{tabular}

\section{Comparison 9}

Effect: Trial * Time

\begin{tabular}{|l|r|}
\hline \multicolumn{2}{|l|}{ Without min 5 vs. Without $\min 45$} \\
\hline df & 1 \\
\hline Sum of squares & .004 \\
\hline Mean square & .004 \\
\hline F-Value & 46.147 \\
\hline P-Value & .0001 \\
\hline G-G & .0001 \\
\hline H-F & .0001 \\
\hline
\end{tabular}

\section{Comparison 6}

Effect: Trial * Time

\begin{tabular}{|l|r|}
\hline \multicolumn{2}{|l|}{ With min 5 vs. With $\min 25$} \\
\hline df & 1 \\
\hline Sum of squares & $4.893 \mathrm{E}-4$ \\
\hline Mean square & $4.893 \mathrm{E}-4$ \\
\hline F-Value & 5.701 \\
\hline P-Value & .0239 \\
\hline G-G & .0471 \\
\hline H-F & .0250 \\
\hline
\end{tabular}

\section{Comparison 8}

Effect: Trial * Time

\begin{tabular}{|l|r|}
\hline \multicolumn{2}{|l|}{ Without min 5 vs. Without min 25 } \\
\hline df & 1 \\
\hline Sum of squares & .004 \\
\hline Mean square & .004 \\
\hline F-Value & 42.178 \\
\hline P-Value & .0001 \\
\hline G-G & .0001 \\
\hline H-F & .0001 \\
\hline
\end{tabular}




\section{Group 2 HR}

Type III Sums of Squares

\begin{tabular}{|c|c|c|c|c|c|c|c|}
\hline Source & $d f$ & Sum of Squares & Mean Square & F-Value & P-Value & G-G & $\mathrm{H}-\mathrm{F}$ \\
\hline Subject & 7 & 6017.780 & 859.683 & & & & \\
\hline Trial & 1 & 3.354 & 3.354 & .007 & .9354 & .9354 & .9354 \\
\hline Trial * Subject & 7 & 3326.857 & 475.265 & & & & \\
\hline time & 4 & 3756.457 & 939.114 & 46.169 & .0001 & .0001 & .0001 \\
\hline time * Subject & 28 & 569.541 & 20.341 & & & & \\
\hline Trial * time & 4 & 20.426 & 5.106 & .547 & .7025 & .6418 & .7025 \\
\hline Trial * time * $\mathbf{S} .$. & 28 & 261.277 & 9.331 & & & & \\
\hline
\end{tabular}

Dependent: HR

Means Table

Effect: Trial

Dependent: HR

\begin{tabular}{|c|c|c|c|c|}
\hline & Count & Mean & Std. Dev. & Std. Error \\
\hline with & 40 & 155.337 & 13.517 & 2.137 \\
\hline without & 40 & 155.747 & 13.230 & 2.092 \\
\hline
\end{tabular}

\begin{tabular}{|c|c|c|c|c|}
\hline \multicolumn{5}{|c|}{$\begin{array}{l}\text { Means Table } \\
\text { Effect: time } \\
\text { Dependent: HR }\end{array}$} \\
\hline & Count & Mean & Std. Dev. & Std. Error \\
\hline $5 \mathrm{~min}$ & 16 & 143.413 & 14.505 & 3.626 \\
\hline $15 \mathrm{~min}$ & 16 & 153.516 & 11.790 & 2.947 \\
\hline $25 \mathrm{~min}$ & 16 & 157.170 & 11.017 & 2.754 \\
\hline $35 \mathrm{~min}$ & 16 & 160.703 & 9.938 & 2.484 \\
\hline $45 \mathrm{~min}$ & 16 & 162.909 & 10.508 & 2.627 \\
\hline
\end{tabular}

\section{Means Table \\ Effect: Trial * time \\ Dependent: HR}

with, $5 \mathrm{~min}$

with, $15 \mathrm{~min}$

with, 25 min

with, $35 \mathrm{~min}$ with, $45 \mathrm{~min}$ without, $5 \mathrm{~min}$ without, $15 \mathrm{~min}$ without, $25 \mathrm{~min}$ without, $35 \mathrm{~min}$ without, $45 \mathrm{~min}$

\begin{tabular}{|c|c|c|c|}
\hline Count & Mean & Std. Dev. & Std. Error \\
\hline 8 & 142.289 & 14.727 & 5.207 \\
\hline 8 & 153.229 & 12.811 & 4.529 \\
\hline 8 & 157.065 & 11.083 & 3.919 \\
\hline 8 & 161.014 & 9.722 & 3.437 \\
\hline 8 & 163.090 & 10.535 & 3.725 \\
\hline 8 & 144.536 & 15.202 & 5.375 \\
\hline 8 & 153.804 & 11.556 & 4.086 \\
\hline 8 & 157.275 & 11.715 & 4.142 \\
\hline 8 & 160.391 & 10.811 & 3.822 \\
\hline 8 & 162.728 & 11.204 & 3.961 \\
\hline
\end{tabular}




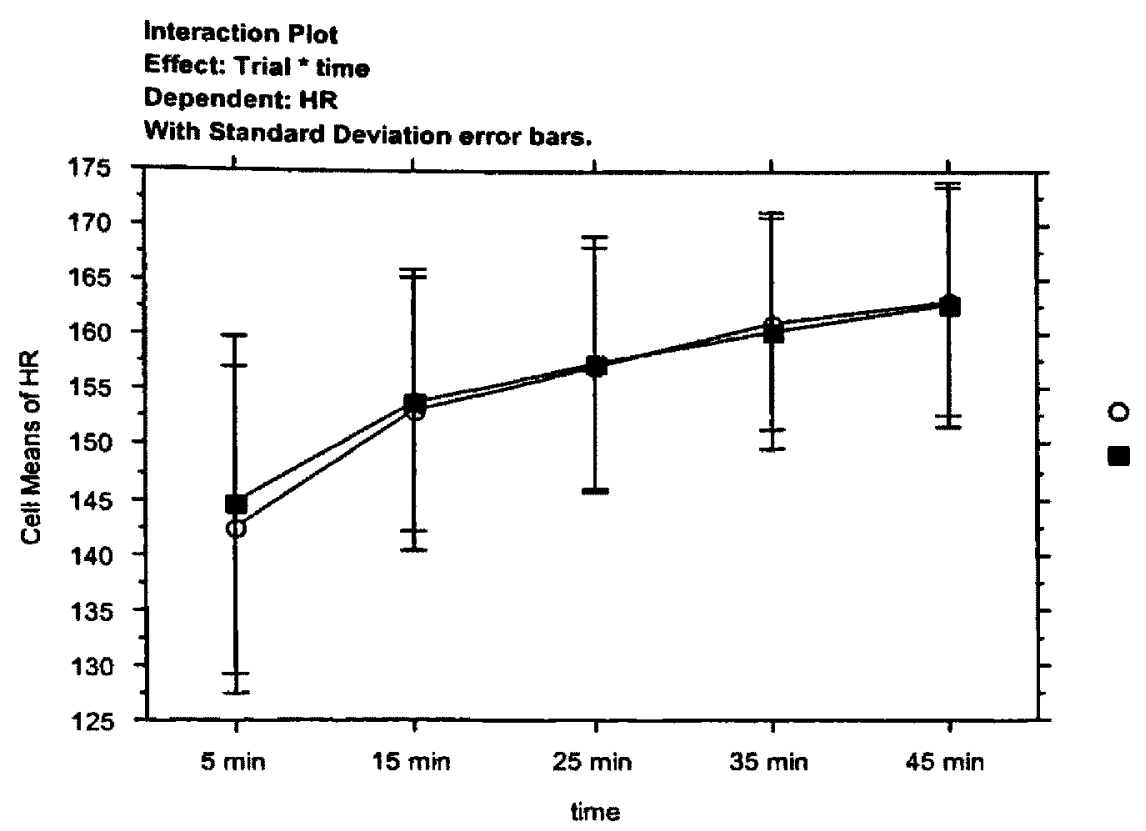

Comparison 1

Effect: Trial * Time

\begin{tabular}{|l|r|}
\hline \multicolumn{2}{|l|}{ With min 5 vs. Without min 5 } \\
\hline df & 1 \\
\hline Sum of squares & 20.205 \\
\hline Mean square & 20.205 \\
\hline F-Value & 2.165 \\
\hline P-Value & .1523 \\
\hline G-G & .1569 \\
\hline H-F & .1523 \\
\hline
\end{tabular}

Comparison 3

Effect: Trial * Time

\begin{tabular}{|l|r|}
\hline With min 25 vs. Without min 25 \\
\hline df & 1 \\
\hline Sum of squares & .176 \\
\hline Mean square & .176 \\
\hline F-Value & .019 \\
\hline P-Value & .8916 \\
\hline G-G & .8048 \\
\hline H-F & .8916 \\
\hline
\end{tabular}

Comparison 2

Effect: Trial * Time

\begin{tabular}{|l|r|}
\hline \multicolumn{2}{|l|}{ With min 15 vs. Without min 15 } \\
\hline df & 1 \\
\hline Sum of squares & 1.323 \\
\hline Mean square & 1.323 \\
\hline F-Value & .142 \\
\hline P-Value & .7094 \\
\hline G-G & .6135 \\
\hline H-F & .7094 \\
\hline
\end{tabular}

Comparison 4

Effect: Trial * Time

\begin{tabular}{|l|r|}
\hline With $\min 35$ vs. Without $\min 35$ \\
\hline df & 1 \\
\hline Sum of squares & 1.550 \\
\hline Mean square & 1.550 \\
\hline F-Value & .166 \\
\hline P-Value & .6867 \\
\hline G-G & .5926 \\
\hline H-F & .6867 \\
\hline
\end{tabular}


Comparison 5

Effect: Trial * Time

\begin{tabular}{|l|r|}
\hline \multicolumn{2}{|l|}{ With min 45 vs. Without min45 } \\
\hline df & 1 \\
\hline Sum of squares & .526 \\
\hline Mean square & .526 \\
\hline F-Value & .056 \\
\hline P-Value & .8141 \\
\hline G-G & .7166 \\
\hline H-F & .8141 \\
\hline
\end{tabular}

Comparison 7

Effect: Trial * Time

\begin{tabular}{|l|r|}
\hline \multicolumn{2}{|l|}{ With min 5 vs. With min 45 } \\
\hline df & 1 \\
\hline Sum of squares & 1730.768 \\
\hline Mean square & 1730.768 \\
\hline F-Value & 185.479 \\
\hline P-Value & .0001 \\
\hline G-G & .0001 \\
\hline H-F & .0001 \\
\hline
\end{tabular}

\section{Comparison 6}

Effect: Trial * Time

\begin{tabular}{|l|r|}
\hline \multicolumn{2}{|l|}{ With min 5 vs. With $\min 25$} \\
\hline df & 1 \\
\hline Sum of squares & 873.350 \\
\hline Mean square & 873.350 \\
\hline F-Value & 93.593 \\
\hline P-Value & .0001 \\
\hline G-G & .0001 \\
\hline H-F & .0001 \\
\hline
\end{tabular}

\section{Comparison 9}

\section{Effect: Trial * Time}

\begin{tabular}{|l|r|}
\hline Without min 5 vs. Without min 45 \\
\hline df & 1 \\
\hline Sum of squares & 1323.686 \\
\hline Mean square & 1323.686 \\
\hline F-Value & 141.854 \\
\hline P-Value & .0001 \\
\hline G-G & .0001 \\
\hline H-F & .0001 \\
\hline
\end{tabular}

\begin{tabular}{|l|r|}
\hline Without min 5 vs. Without min 25 \\
\hline df & 1 \\
\hline Sum of squares & 649.103 \\
\hline Mean square & 649.103 \\
\hline F-Value & 69.562 \\
\hline P-Value & .0001 \\
\hline G-G & .0001 \\
\hline H-F & .0001 \\
\hline
\end{tabular}

Comparison 8

Effect: Trial ${ }^{*}$ Time 


\section{Group 2 Fat utilization}

Type III Sums of Squares

\begin{tabular}{|c|c|c|c|c|c|c|c|}
\hline Source & $d f$ & Sum of Squares & Mean Square & F-Value & P-Value & G-G & $\mathrm{H}-\mathrm{F}$ \\
\hline Subject & 7 & 393.254 & 56.179 & & & & \\
\hline Trial & 1 & 31.088 & 31.088 & 4.591 & .0694 & .0694 & .0694 \\
\hline Trial * Subject & 7 & 47.403 & 6.772 & & & & \\
\hline time & 4 & 38.647 & 9.662 & 3.235 & .0266 & .0927 & .0810 \\
\hline time * Subject & 28 & 83.627 & 2.987 & & & & \\
\hline Trial * time & 4 & 6.611 & 1.653 & 3.471 & .0201 & .0443 & .0201 \\
\hline Trial * time ${ }^{*} \mathbf{S}$. & 28 & 13.334 & .476 & & & & \\
\hline
\end{tabular}

Dependent: Fat oxidation ( $\mu \mathrm{mol} / \mathrm{kg} / \mathrm{min})$

\begin{tabular}{|c|c|c|c|c|}
\hline \multicolumn{5}{|c|}{$\begin{array}{l}\text { Means Table } \\
\text { Effect: Trial } \\
\text { Dependent: Fat oxidation ( } \mu \text { moi/kg/min) }\end{array}$} \\
\hline & Count & Mean & Std. Dev. & Std. Error \\
\hline \multirow{2}{*}{$\begin{array}{l}\text { with } \\
\text { without }\end{array}$} & 40 & 7.813 & 2.860 & .452 \\
\hline & 40 & 6.566 & 2.601 & .411 \\
\hline
\end{tabular}

\section{Means Table}

Effect: time

Dependent: Fat oxidation ( $\mu \mathrm{mol} / \mathbf{k g} / \mathrm{min}$ )

\begin{tabular}{|c|c|c|c|c|}
\hline & Count & Mean & Std. Dev. & Std. Error \\
\hline $5 \mathrm{~min}$ & 16 & 6.018 & 4.091 & 1.023 \\
\hline $15 \mathrm{~min}$ & 16 & 6.948 & 2.580 & .645 \\
\hline $25 \mathrm{~min}$ & 16 & 7.485 & 2.461 & .615 \\
\hline $35 \mathrm{~min}$ & 16 & 7.381 & 2.147 & .537 \\
\hline $45 \mathrm{~min}$ & 16 & 8.118 & 2.074 & .518 \\
\hline
\end{tabular}

\begin{tabular}{|c|c|c|c|c|}
\hline \multicolumn{5}{|c|}{$\begin{array}{l}\text { Means Table } \\
\text { Effect: Trial " time } \\
\text { Dependent: Fat oxidation ( } \mathrm{\mu mol} / \mathrm{kg} / \mathrm{min} \text { ) }\end{array}$} \\
\hline & Count & Mean & Std. Dev. & Std. Error \\
\hline \multirow{2}{*}{$\begin{array}{l}\text { with, } 5 \mathrm{~min} \\
\text { with, } 15 \mathrm{~min}\end{array}$} & 8 & 7.079 & 4.152 & 1.468 \\
\hline & 8 & 7.608 & 2.989 & 1.057 \\
\hline with, $25 \mathrm{~min}$ & 8 & 8.010 & 2.830 & 1.001 \\
\hline \multirow{2}{*}{$\begin{array}{l}\text { with, } 35 \mathrm{~min} \\
\text { with, } 45 \mathrm{~min}\end{array}$} & 8 & 7.551 & 2.309 & .816 \\
\hline & 8 & 8.819 & 2.028 & .717 \\
\hline \multirow{2}{*}{$\begin{array}{l}\text { without, } 5 \mathrm{~min} \\
\text { without, } 15 \mathrm{~min}\end{array}$} & 8 & 4.957 & 4.006 & 1.416 \\
\hline & 8 & 6.289 & 2.082 & .736 \\
\hline \multirow{2}{*}{$\begin{array}{l}\text { without, } 25 \mathrm{~min} \\
\text { without, } 35 \mathrm{~min}\end{array}$} & 8 & 6.960 & 2.082 & .736 \\
\hline & 8 & 7.210 & 2.115 & .748 \\
\hline without, $45 \mathrm{~min}$ & 8 & 7.416 & 1.994 & .705 \\
\hline
\end{tabular}




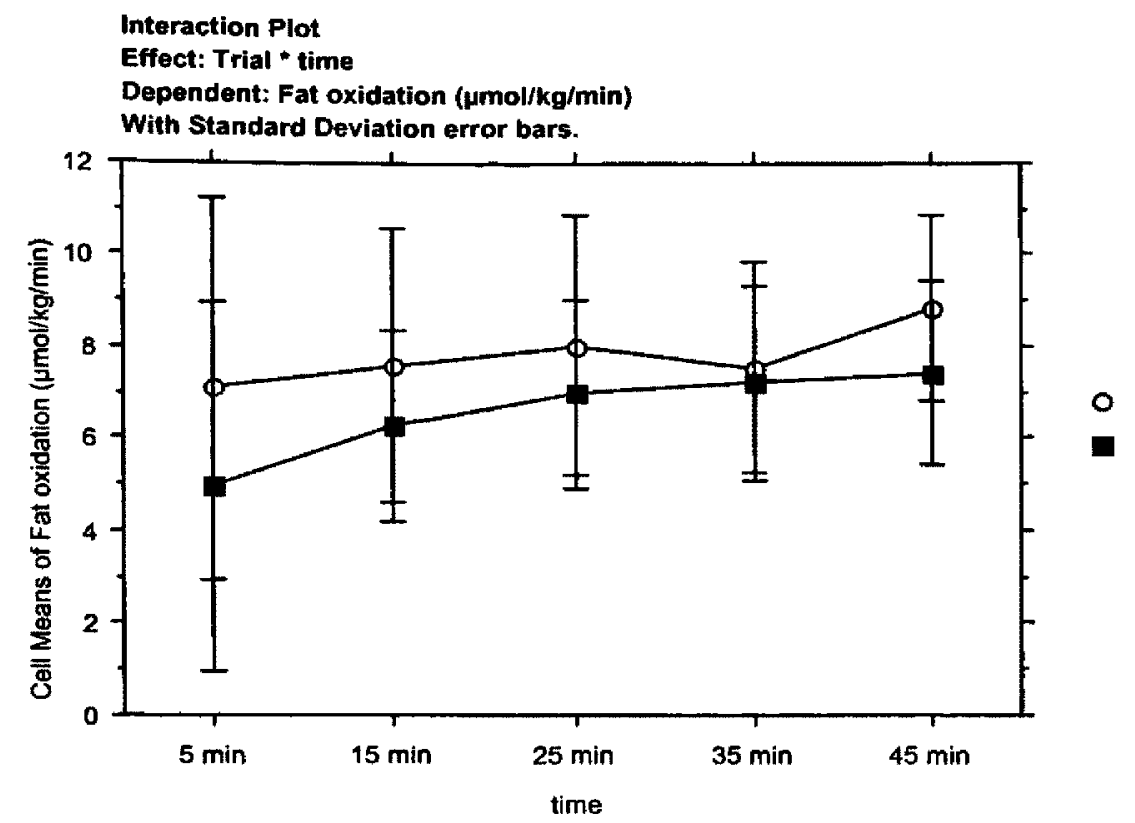

Comparison 1

Effect: Trial * Time

\begin{tabular}{|l|r|}
\hline With min 5 vs. Without min 5 \\
\hline df & 1 \\
\hline Sum of squares & 17.999 \\
\hline Mean square & 17.999 \\
\hline F-Value & 37.796 \\
\hline P-Value & .0001 \\
\hline G-G & .0001 \\
\hline H-F & .0001 \\
\hline
\end{tabular}

Comparison 3

Effect: Trial * Time

\begin{tabular}{|l|r|}
\hline \multicolumn{2}{|l|}{ With min 25 vs. Without $\min 25$} \\
\hline df & 1 \\
\hline Sum of squares & 4.410 \\
\hline Mean square & 4.410 \\
\hline F-Value & 9.261 \\
\hline P-Value & .0050 \\
\hline G-G & .0137 \\
\hline H-F & .0050 \\
\hline
\end{tabular}

Comparison 2 Effect: Trial * Time

\begin{tabular}{|l|r|}
\hline With min 15 vs. Without min 15 \\
\hline df & 1 \\
\hline Sum of squares & 6.956 \\
\hline Mean square & 6.956 \\
\hline F-Value & 14.608 \\
\hline P-Value & .0007 \\
\hline G-G & .0035 \\
\hline H-F & .0007 \\
\hline
\end{tabular}


Comparison 5

Effect: Trial * Time

\begin{tabular}{|l|r|}
\hline With min 45 vs. Without min45 \\
\hline df & 1 \\
\hline Sum of squares & 7.868 \\
\hline Mean square & 7.868 \\
\hline F-Value & 16.522 \\
\hline P-Value & .0004 \\
\hline G-G & .0023 \\
\hline H-F & .0004 \\
\hline
\end{tabular}

Comparison 7

Effect: Trial * Time

\begin{tabular}{|l|r|}
\hline \multicolumn{2}{|l|}{ With min 5 vs. With min 45 } \\
\hline df & 1 \\
\hline Sum of squares & 12.110 \\
\hline Mean square & 12.110 \\
\hline F-Value & 25.431 \\
\hline P-Value & .0001 \\
\hline G-G & .0004 \\
\hline H-F & .0001 \\
\hline
\end{tabular}

\section{Comparison 6}

Effect: Trial * Time

\begin{tabular}{|l|r|}
\hline \multicolumn{2}{|l|}{ With $\min 5$ vs. With $\min 25$} \\
\hline df & 1 \\
\hline Sum of squares & 3.469 \\
\hline Mean square & 3.469 \\
\hline F-Value & 7.284 \\
\hline P-Value & .0117 \\
\hline G-G & .0245 \\
\hline H-F & .0117 \\
\hline
\end{tabular}

\section{Comparison 8}

Effect: Trial * Time

\begin{tabular}{|l|r|}
\hline Without min 5 vs. Without $\min 25$ \\
\hline df & 1 \\
\hline Sum of squares & 16.040 \\
\hline Mean square & 16.040 \\
\hline F-Value & 33.683 \\
\hline P-Value & .0001 \\
\hline G-G & .0001 \\
\hline H-F & .0001 \\
\hline
\end{tabular}

\section{Comparison 9}

Effect: Trial * Time

\begin{tabular}{|l|r|}
\hline Without min 5 vs. Without min 45 \\
\hline df & 1 \\
\hline Sum of squares & 24.182 \\
\hline Mean square & 24.182 \\
\hline F-Value & 50.780 \\
\hline P-Value & .0001 \\
\hline G-G & .0001 \\
\hline H-F & .0001 \\
\hline
\end{tabular}




\section{Group 2 CHO}

Type III Sums of Squares

\begin{tabular}{|c|c|c|c|c|c|c|c|}
\hline Source & df & Sum of Squares & Mean Square & F-Value & P-Value & G.G & H-F \\
\hline Subject & 7 & 80034.763 & 11433.538 & & & & \\
\hline Trial & 1 & 2405.392 & 2405.392 & 3.405 & 1075 & .1075 & .1075 \\
\hline Trial * Subject & 7 & 4944.986 & 706.427 & & & & \\
\hline time & 4 & 2291.994 & 572.999 & 1.016 & .4159 & .3698 & 3796 \\
\hline time " Subject & 28 & 15786.211 & 563.793 & & & & \\
\hline Trial * time & 4 & 1973.155 & 493.289 & 4.923 & .0039 & .0176 & .0057 \\
\hline Trial * time * $\mathbf{S}$ & 28 & 2805.751 & 100.205 & & & & \\
\hline
\end{tabular}

Dependent: $\mathrm{CHO}$ oxidation ( $\mu \mathrm{mol} / \mathrm{kg} / \mathrm{min}$ )

Means Table

Effect: Trial

Dependent: CHO oxidation ( $\mu \mathrm{mol} / \mathrm{kg} / \mathrm{min}$ )

\begin{tabular}{|c|c|c|c|c|}
\hline & Count & Mean & Std. Dev. & Std. Error \\
\hline with & 40 & 175.558 & 35.049 & 5.542 \\
\hline without & 40 & 186.524 & 39.200 & 6.198 \\
\hline
\end{tabular}

\section{Means Tabie}

Effect: time

Dependent: CHO oxidation ( $\mu \mathrm{mol} / \mathrm{kg} / \mathrm{min}$ )

\begin{tabular}{|c|c|c|c|c|}
\hline & Count & Mean & Std. Dev. & Std. Error \\
\hline $5 \mathrm{~min}$ & 16 & 190.494 & 48.575 & 12.144 \\
\hline $15 \mathrm{~min}$ & 16 & 182.629 & 30.998 & 7.749 \\
\hline $25 \mathrm{~min}$ & 16 & 175.221 & 30.899 & 7.725 \\
\hline $35 \mathrm{~min}$ & 16 & 179.822 & 34.320 & 8.580 \\
\hline $45 \mathrm{~min}$ & 16 & 177.039 & 41.758 & 10.439 \\
\hline
\end{tabular}

Means Table

Effect: Trial * time

Dependent: CHO oxidation ( $\mu \mathrm{mol} / \mathrm{kg} / \mathrm{min}$ )

\begin{tabular}{|c|c|c|c|c|}
\hline & Count & Mean & Std. Dev. & Std. Error \\
\hline with, $5 \mathrm{~min}$ & 8 & 176.470 & 43.580 & 15.408 \\
\hline with, $15 \mathrm{~min}$ & 8 & 177.061 & 28.832 & 10.194 \\
\hline with, $25 \mathrm{~min}$ & 8 & 172.626 & 31.488 & 11.133 \\
\hline with, $35 \mathrm{~min}$ & 8 & 180.784 & 34.889 & 12.335 \\
\hline with, $45 \mathrm{~min}$ & 8 & 170.848 & 42.836 & 15.145 \\
\hline without, $5 \mathrm{~min}$ & 8 & 204.518 & 52.032 & 18.396 \\
\hline without, $15 \mathrm{~min}$ & 8 & 188.197 & 34.012 & 12.025 \\
\hline without, $25 \mathrm{~min}$ & 8 & 177.816 & 32.233 & 11.396 \\
\hline without, $35 \mathrm{~min}$ & 8 & 178.861 & 36.120 & 12.770 \\
\hline ithout, $45 \mathrm{~min}$ & 8 & 183.230 & 42.592 & 15.058 \\
\hline
\end{tabular}




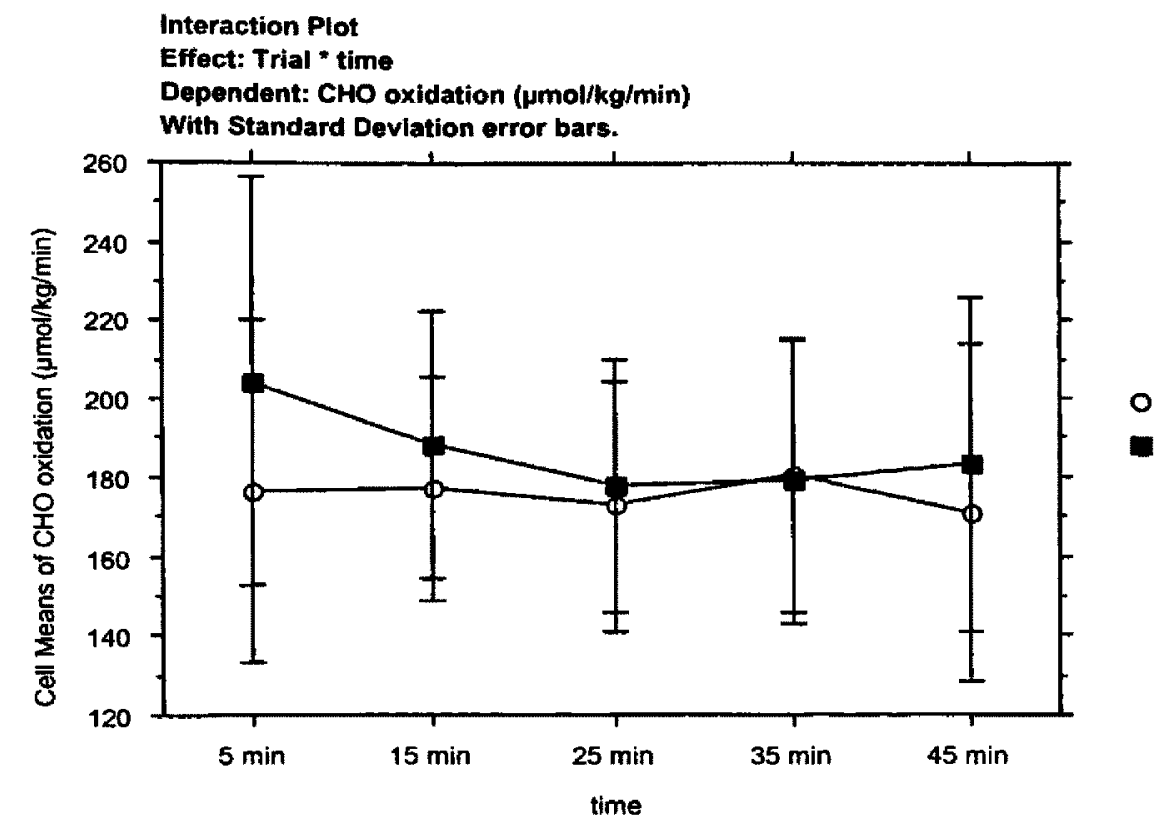

Comparison 1

Effect: Trial * Time

\begin{tabular}{|l|r|}
\hline With min 5 vs. Without min 5 \\
\hline df & 1 \\
\hline Sum of squares & 3146.649 \\
\hline Mean square & 3146.649 \\
\hline F-Value & 31.402 \\
\hline P-Value & .0001 \\
\hline G-G & .0002 \\
\hline H-F & .0001 \\
\hline
\end{tabular}

Comparison 2

Effect: Trial * Time

\begin{tabular}{|l|r|}
\hline \multicolumn{2}{|l|}{ With min 15 vs. Without min 15 } \\
\hline df & 1 \\
\hline Sum of squares & 496.064 \\
\hline Mean square & 496.064 \\
\hline F-Value & 4.950 \\
\hline P-Value & .0343 \\
\hline G-G & .0552 \\
\hline H-F & .0389 \\
\hline
\end{tabular}

Comparison 3

Effect: Trial * Time

\begin{tabular}{|l|r|}
\hline With min 25 vs. Without min 25 \\
\hline df & 1 \\
\hline Sum of squares & 107.744 \\
\hline Mean square & 107.744 \\
\hline F-Value & 1.075 \\
\hline P-Value & .3086 \\
\hline G-G & .2688 \\
\hline H-F & .3009 \\
\hline
\end{tabular}

Comparison 4

Effect: Trial * Time

\begin{tabular}{|l|r|}
\hline \multicolumn{2}{|l|}{ With min 35 vs. Without $\min 35$} \\
\hline df & 1 \\
\hline Sum of squares & 14.784 \\
\hline Mean square & 14.784 \\
\hline F-Value & .148 \\
\hline P-Value & .7038 \\
\hline G-G & .5657 \\
\hline H-F & .6752 \\
\hline
\end{tabular}


Comparison 5

Effect: Trial * Time

\begin{tabular}{|l|r|}
\hline With $\min 45$ vs. Without $\min 45$ \\
\hline df & 1 \\
\hline Sum of squares & 613.305 \\
\hline Mean square & 613.305 \\
\hline F-Value & 6.120 \\
\hline P-Value & .0197 \\
\hline G-G & .0381 \\
\hline H-F & .0234 \\
\hline
\end{tabular}

Comparison 7

Effect: Trial * Time

\begin{tabular}{|l|r|}
\hline With $\min 5$ vs. With $\min 45$ \\
\hline df & 1 \\
\hline Sum of squares & 126.450 \\
\hline Mean square & 126.450 \\
\hline F-Value & 1.262 \\
\hline P-Value & .2708 \\
\hline G-G & .2423 \\
\hline H-F & .2657 \\
\hline
\end{tabular}

Comparison 6

Effect: Trial * Time

\begin{tabular}{|l|r|}
\hline \multicolumn{2}{|l|}{ With min 5 vs. With min 25 } \\
\hline df & 1 \\
\hline Sum of squares & 59.098 \\
\hline Mean square & 59.098 \\
\hline F-Value & .590 \\
\hline P-Value & .4489 \\
\hline G-G & .3677 \\
\hline H-F & .4317 \\
\hline
\end{tabular}

Comparison 8

Effect: Trial * Time

\begin{tabular}{|l|r|}
\hline \multicolumn{2}{|l|}{ Without min 5 vs. Without min 25 } \\
\hline df & 1 \\
\hline Sum of squares & 2851.827 \\
\hline Mean square & 2851.827 \\
\hline F-Value & 28.460 \\
\hline P-Value & .0001 \\
\hline G-G & .0004 \\
\hline H-F & .0001 \\
\hline
\end{tabular}

Comparison 9

Effect: Trial * Time

\begin{tabular}{|l|r|}
\hline Without min 5 vs. Without min 45 \\
\hline df & 1 \\
\hline Sum of squares & 1812.631 \\
\hline Mean square & 1812.631 \\
\hline F-Value & 18.089 \\
\hline P-Value & .0002 \\
\hline G-G & .0022 \\
\hline H-F & .0004 \\
\hline
\end{tabular}




\section{Group 2 RPE}

Type III Sums of Squares

\begin{tabular}{|c|c|c|c|c|c|c|c|}
\hline Source & $d f$ & Sum of Squares & Mean Square & F-Value & P-Value & G-G & $\mathrm{H}-\mathrm{F}$ \\
\hline Subject & 7 & 108.122 & 15.446 & & & & \\
\hline Trial & 1 & 2.278 & 2.278 & .617 & .4579 & .4579 & .4579 \\
\hline Trial * Subject & 7 & 25.847 & 3.692 & & & & \\
\hline time & 4 & 94.331 & 23.583 & 23.154 & .0001 & .0007 & .0004 \\
\hline time ${ }^{*}$ Subject & 28 & 28.519 & 1.019 & & & & \\
\hline Trial * time & 4 & 1.269 & .317 & .539 & .7084 & .5502 & .5811 \\
\hline Trial * time * $\mathrm{S}$. & 28 & 16.481 & .589 & & & & \\
\hline
\end{tabular}

Dependent: RPE

\section{Means Table}

Effect: Trial

Dependent: RPE

\begin{tabular}{|c|c|c|c|c|}
\hline & Count & Mean & Std. Dev. & Std. Error \\
\hline with & 40 & 13.225 & 1.874 & .296 \\
\hline without & 40 & 13.562 & 1.878 & .297 \\
\hline
\end{tabular}

\section{Means Table}

Effect: time

Dependent: RPE

\begin{tabular}{|c|c|c|c|c|}
\hline & Count & Mean & Std. Dev. & Std. Error \\
\hline $5 \mathrm{~min}$ & 16 & 11.781 & 1.303 & .326 \\
\hline $15 \mathrm{~min}$ & 16 & 12.594 & 1.143 & .286 \\
\hline $25 \mathrm{~min}$ & 16 & 13.562 & 1.424 & .356 \\
\hline $35 \mathrm{~min}$ & 16 & 14.281 & 1.673 & .418 \\
\hline $45 \mathrm{~min}$ & 16 & 14.750 & 2.082 & .520 \\
\hline
\end{tabular}

\section{Means Table}

Effect: Trial * time

Dependent: RPE

\begin{tabular}{|c|c|c|c|c|}
\hline & Count & Mean & Std. Dev. & Std. Error \\
\hline with, 5 min & 8 & 11.688 & 1.335 & .472 \\
\hline with, $15 \mathrm{~min}$ & 8 & 12.312 & .884 & .312 \\
\hline with, $25 \mathrm{~min}$ & 8 & 13.562 & 1.237 & .438 \\
\hline with, $35 \mathrm{~min}$ & 8 & 13.938 & 1.935 & .684 \\
\hline with, $45 \mathrm{~min}$ & 8 & 14.625 & 2.264 & .800 \\
\hline without, $5 \mathrm{~min}$ & 8 & 11.875 & 1.356 & .479 \\
\hline without, $15 \mathrm{~min}$ & 8 & 12.875 & 1.356 & .479 \\
\hline without, $25 \mathrm{~min}$ & 8 & 13.562 & 1.678 & .593 \\
\hline without, $35 \mathrm{~min}$ & 8 & 14.625 & 1.408 & .498 \\
\hline without, $45 \mathrm{~min}$ & 8 & 14.875 & 2.031 & .718 \\
\hline
\end{tabular}




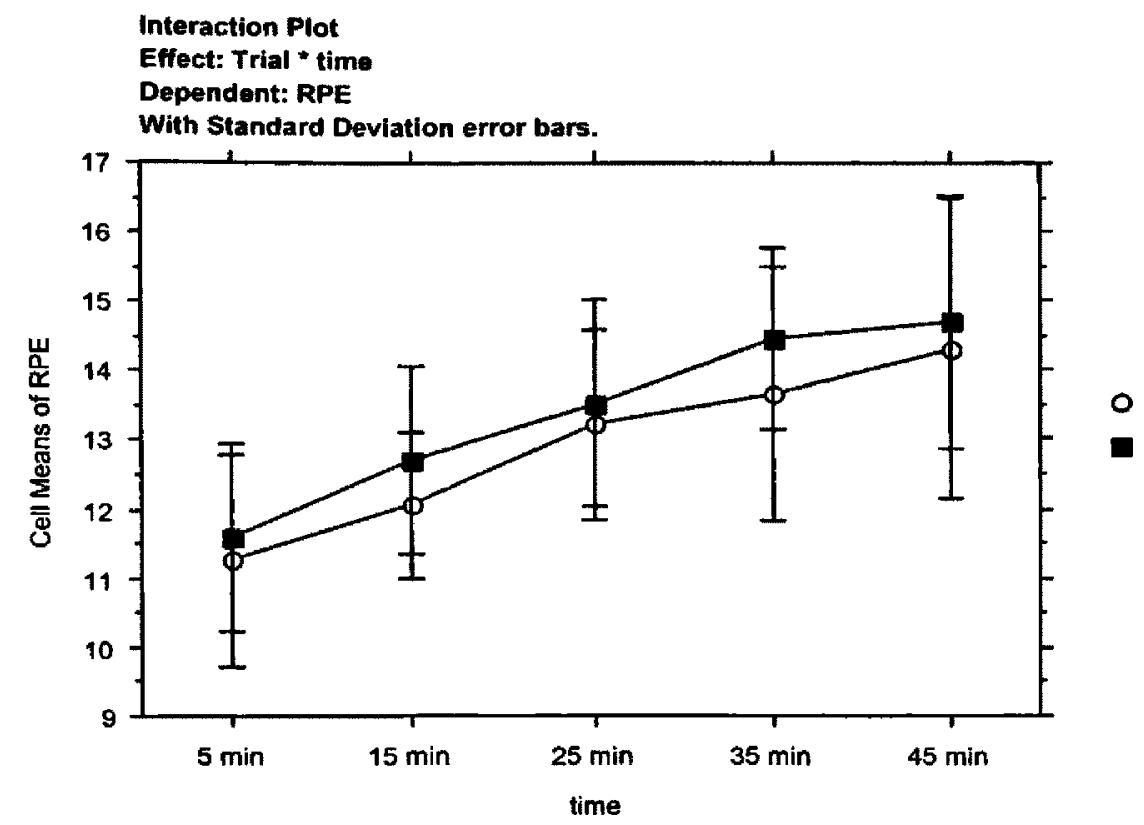

Comparison 1

Effect: Trial * Time
Comparison 2 Effect: Trial * Time

\begin{tabular}{|l|r|}
\hline \multicolumn{2}{|l|}{ With min 5 vs. Without min 5 } \\
\hline df & 1 \\
\hline Sum of squares & .141 \\
\hline Mean square & .141 \\
\hline F-Value & .239 \\
\hline P-Value & .6288 \\
\hline G-G & .4082 \\
\hline H-F & .4494 \\
\hline
\end{tabular}

\begin{tabular}{|l|r|}
\hline \multicolumn{2}{|l|}{ With min 15 vs. Without min 15 } \\
\hline df & 1 \\
\hline Sum of squares & 1.266 \\
\hline Mean square & 1.266 \\
\hline F-Value & 2.150 \\
\hline P-Value & .1537 \\
\hline G-G & .1508 \\
\hline H-F & .1548 \\
\hline
\end{tabular}

\section{Comparison 3}

Effect: Trial * Time

\begin{tabular}{|l|r|}
\hline \multicolumn{2}{|l|}{ With min 25 vs. Without min 25} \\
\hline df & 1 \\
\hline Sum of squares & .0000 \\
\hline Mean square & .0000 \\
\hline F-Value & .0000 \\
\hline P-Value & 1.000 \\
\hline G-G & 1.000 \\
\hline H-F & 1.000 \\
\hline
\end{tabular}

Comparison 4

Effect: Trial * Time

\begin{tabular}{|l|r|}
\hline \multicolumn{2}{|l|}{ With min 35 vs. Without min 35 } \\
\hline df & 1 \\
\hline Sum of squares & 1.891 \\
\hline Mean square & 1.891 \\
\hline F-Value & 3.212 \\
\hline P-Value & .0839 \\
\hline G-G & .1075 \\
\hline H-F & .1061 \\
\hline
\end{tabular}


Comparison 5

Effect: Trial * Time

\begin{tabular}{|l|r|}
\hline \multicolumn{2}{|l|}{ With min 45 vs. Without $\min 45$} \\
\hline df & 1 \\
\hline Sum of squares & .250 \\
\hline Mean square & .250 \\
\hline F-Value & .425 \\
\hline P-Value & .5199 \\
\hline G-G & .3440 \\
\hline H-F & .3767 \\
\hline
\end{tabular}

Comparison 7

Effect: Trial * Time

\begin{tabular}{|l|r|}
\hline With min 5 vs. With $\min 45$ \\
\hline df & 1 \\
\hline Sum of squares & 34.516 \\
\hline Mean square & 34.516 \\
\hline F-Value & 58.639 \\
\hline P-Value & .0001 \\
\hline G-G & .0002 \\
\hline H-F & .0001 \\
\hline
\end{tabular}

Comparison 6

Effect: Trial * Time

\begin{tabular}{|l|r|}
\hline \multicolumn{2}{|l|}{ With min 5 vs. With $\min 25$} \\
\hline df & 1 \\
\hline Sum of squares & 14.062 \\
\hline Mean square & 14.062 \\
\hline F-Value & 23.891 \\
\hline P-Value & .0001 \\
\hline G-G & .0033 \\
\hline H-F & .0019 \\
\hline
\end{tabular}

Comparison 8

Effect: Trial * Time

\begin{tabular}{|l|r|}
\hline Without min 5 vs. Without $\min 25$ \\
\hline $\mathrm{df}$ & 1 \\
\hline Sum of squares & 11.391 \\
\hline Mean square & 11.391 \\
\hline F-Value & 19.352 \\
\hline P-Value & .0001 \\
\hline G-G & .0058 \\
\hline H-F & .0036 \\
\hline
\end{tabular}

\section{Comparison 9}

Effect: Trial * Time

\begin{tabular}{|l|r|}
\hline Without min 5 vs. Without min 45 \\
\hline df & 1 \\
\hline Sum of squares & 36.000 \\
\hline Mean square & 36.000 \\
\hline F-Value & 31.160 \\
\hline P-Value & .0001 \\
\hline G-G & .0001 \\
\hline H-F & .0001 \\
\hline
\end{tabular}




\section{Group 2 Lactate}

Type III Sums of Squares

\begin{tabular}{|c|c|c|c|c|c|c|c|}
\hline Source & $d f$ & Sum of Squares & Mean Square & F-Value & P-Value & G-G & $\mathrm{H}-\mathrm{F}$ \\
\hline Subject & 7 & 140.934 & 20.133 & & & & \\
\hline Trial & 1 & .913 & .913 & .398 & .5480 & .5480 & .5480 \\
\hline Trial * Subject & 7 & 16.050 & 2.293 & & & & \\
\hline time & 4 & 36.539 & 9.135 & 7.256 & .0004 & .0047 & .0009 \\
\hline time * Subject & 28 & 35.252 & $\uparrow .259$ & & & & \\
\hline Trial ${ }^{*}$ time & 4 & 1.311 & .328 & .646 & .6342 & .5515 & .6046 \\
\hline Trial * time * $\mathrm{S}$. & 28 & 14.206 & .507 & & & & \\
\hline
\end{tabular}

Dependent: lactate $(\mathrm{mM})$

\section{Means Table}

Effect: Trial

Dependent: lactate ( $\mathrm{mM})$

\begin{tabular}{|c|c|c|c|c|}
\hline & Count & Mean & Std. Dev. & Std. Error \\
\hline with & 40 & 3.442 & 1.626 & .257 \\
\hline without & 40 & 3.656 & 1.903 & .301 \\
\hline
\end{tabular}

Means Table

Effect: time

Dependent: lactate (mM)

\begin{tabular}{|c|c|c|c|c|}
\hline & Count & Mean & Std. Dev. & Std. Error \\
\hline $0 \mathrm{~min}$ & 16 & 2.257 & 1.033 & .258 \\
\hline $15 \mathrm{~min}$ & 16 & 3.510 & 1.870 & .467 \\
\hline $25 \mathrm{~min}$ & 16 & 3.874 & 1.805 & .451 \\
\hline $35 \mathrm{~min}$ & 16 & 4.070 & 1.688 & .422 \\
\hline $45 \mathrm{~min}$ & 16 & 4.035 & 1.801 & .450 \\
\hline
\end{tabular}

\begin{tabular}{|c|c|c|c|c|}
\hline \multicolumn{5}{|c|}{$\begin{array}{l}\text { Means Table } \\
\text { Effect: Trial " time } \\
\text { Dependent: lactate (mM) }\end{array}$} \\
\hline & Count & Mean & Std. Dev. & Std. Error \\
\hline \multirow{3}{*}{$\begin{array}{l}\text { with, } 0 \mathrm{~min} \\
\text { with, } 15 \mathrm{~min} \\
\text { with, } 25 \mathrm{~min}\end{array}$} & 8 & 2.247 & 1.062 & .375 \\
\hline & 8 & 3.438 & 1.856 & .656 \\
\hline & 8 & 3.929 & 1.690 & .598 \\
\hline with, $35 \mathrm{~min}$ & 8 & 3.850 & 1.542 & .545 \\
\hline \multirow{2}{*}{$\begin{array}{l}\text { with, } 45 \mathrm{~min} \\
\text { without, } 0 \mathrm{~min}\end{array}$} & 8 & 3.748 & 1.649 & .583 \\
\hline & 8 & 2.267 & 1.076 & .381 \\
\hline \multirow{2}{*}{$\begin{array}{l}\text { without, } 15 \mathrm{~min} \\
\text { without, } 25 \mathrm{~min}\end{array}$} & 8 & 3.583 & 2.008 & .710 \\
\hline & 8 & 3.819 & 2.029 & .717 \\
\hline \multirow{2}{*}{$\begin{array}{l}\text { without, } 35 \mathrm{~min} \\
\text { without, } 45 \mathrm{~min}\end{array}$} & 8 & 4.290 & 1.902 & .672 \\
\hline & 8 & 4.321 & 2.010 & .711 \\
\hline
\end{tabular}




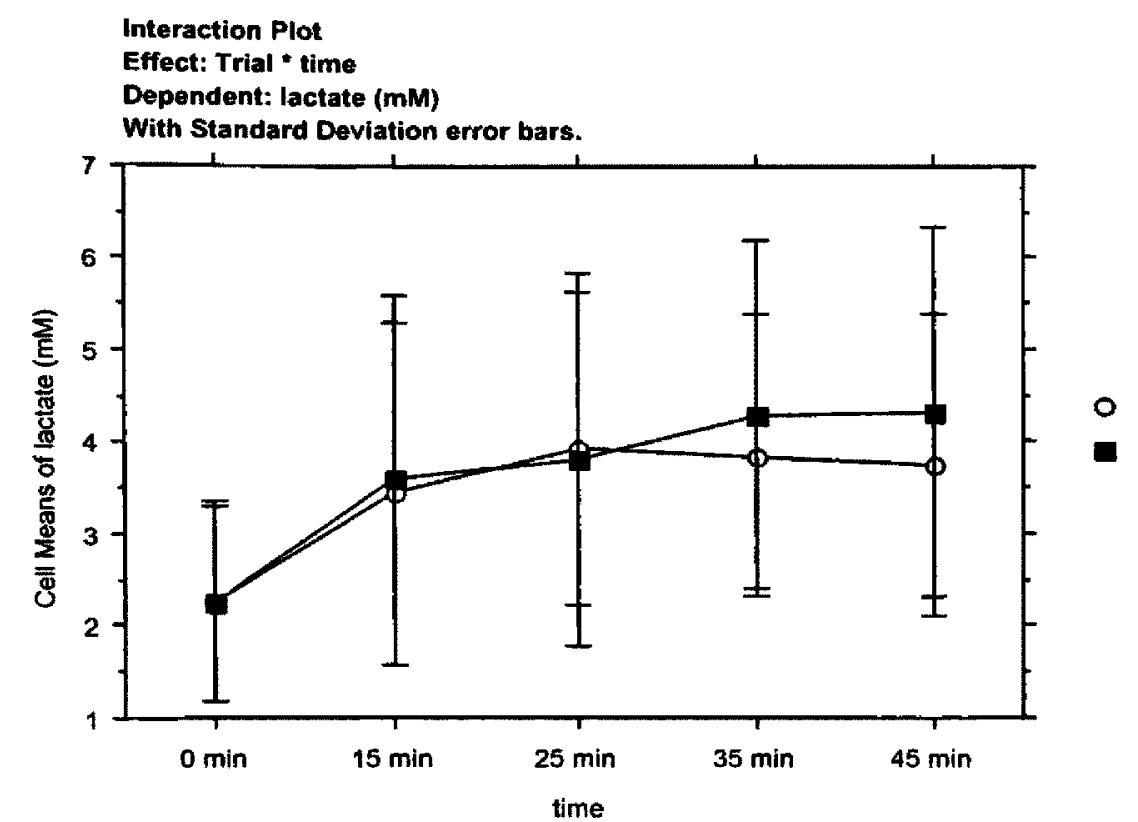

Comparison 1

Effect: Trial * Time

\begin{tabular}{|l|r|}
\hline \multicolumn{2}{|l|}{ With min 5 vs. Without min 5 } \\
\hline df & .002 \\
\hline Sum of squares & .002 \\
\hline Mean square & .003 \\
\hline F-Value & .9567 \\
\hline P-Value & .8441 \\
\hline G-G & .9263 \\
\hline H-F & \\
\hline
\end{tabular}

Comparison 3

Effect: Trial * Time

\begin{tabular}{|l|r|}
\hline \multicolumn{2}{|l|}{ With min 25 vs. Without $\min 25$} \\
\hline df & 1 \\
\hline Sum of squares & .048 \\
\hline Mean square & .048 \\
\hline F-Value & .095 \\
\hline P-Value & .7597 \\
\hline G-G & .5994 \\
\hline H-F & .7045 \\
\hline
\end{tabular}

Comparison 2

Effect: Trial * Time

\begin{tabular}{|l|r|}
\hline \multicolumn{2}{|l|}{ With min 15 vs. Without $\min 15$} \\
\hline df & 1 \\
\hline Sum of squares & .085 \\
\hline Mean square & .085 \\
\hline F-Value & .167 \\
\hline P-Value & .6862 \\
\hline G-G & .5352 \\
\hline H-F & .6328 \\
\hline
\end{tabular}

Comparison 4

Effect: Trial * Time

\begin{tabular}{|l|r|}
\hline \multicolumn{2}{|l|}{ With min 35 vs. Without $\min 35$} \\
\hline df & 1 \\
\hline Sum of squares & .774 \\
\hline Mean square & .774 \\
\hline F-Value & 1.526 \\
\hline P-Value & .2269 \\
\hline G-G & .2087 \\
\hline H-F & .2222 \\
\hline
\end{tabular}


Comparison 5

Effect: Trial * Time

\begin{tabular}{|l|r|}
\hline \multicolumn{2}{|l|}{ With min 45 vs. Without min45 } \\
\hline df & 1 \\
\hline Sum of squares & 1.316 \\
\hline Mean square & 1.316 \\
\hline F-Value & 2.593 \\
\hline P-Value & .1185 \\
\hline G-G & .1310 \\
\hline H-F & .1250 \\
\hline
\end{tabular}

Comparison 7

Effect: Trial * Time

\begin{tabular}{|l|r|}
\hline With $\min$ 5 vs. With $\min 45$ \\
\hline df & 1 \\
\hline Sum of squares & 9.008 \\
\hline Mean square & 9.008 \\
\hline F-Value & 17.754 \\
\hline P-Value & .0002 \\
\hline G-G & .0028 \\
\hline H-F & .0007 \\
\hline
\end{tabular}

Comparison 6

Effect: Trial $*$ Time

\begin{tabular}{|l|r|}
\hline \multicolumn{2}{|l|}{ With min 5 vs. With $\min 25$} \\
\hline df & 1 \\
\hline Sum of squares & 11.308 \\
\hline Mean square & 11.308 \\
\hline F-Value & 22.289 \\
\hline P-Value & .0001 \\
\hline G-G & .0013 \\
\hline H-F & .0002 \\
\hline
\end{tabular}

Comparison 8

Effect: Trial $*$ Time

\begin{tabular}{|l|r|}
\hline Without min 5 vs. Without min 25 \\
\hline df & 1 \\
\hline Sum of squares & 9.633 \\
\hline Mean square & 9.633 \\
\hline F-Value & 18.987 \\
\hline P-Value & .0002 \\
\hline G-G & .0022 \\
\hline H-F & .0005 \\
\hline
\end{tabular}

\section{Comparison 9}

Effect: Trial * Time

\begin{tabular}{|l|r|}
\hline Without min 5 vs. Without min 45 \\
\hline df & 1 \\
\hline Sum of squares & 16.886 \\
\hline Mean square & 16.886 \\
\hline F-Value & 33.283 \\
\hline P-Value & .0001 \\
\hline G-G & .0002 \\
\hline H-F & .0001 \\
\hline
\end{tabular}




\section{Group 2 Temperature}

Type III Sums of Squares

\begin{tabular}{|c|c|c|c|c|c|c|c|}
\hline Source & df & Sum of Squares & Mean Square & F-Value & P-Value & $G-G$ & $H-F$ \\
\hline Subject & 7 & 18.281 & 2.612 & & & & \\
\hline trial & 1 & .029 & .029 & .032 & .8628 & .8628 & .8628 \\
\hline trial * Subject & 7 & 6.405 & .915 & & & & \\
\hline time & 6 & 47.198 & 7.866 & 168.904 & .0001 & .0001 & .0001 \\
\hline time * Subject & 42 & 1.956 & .047 & & & & \\
\hline trial * time & 6 & .100 & .017 & .397 & 8766 & 6714 & .7312 \\
\hline trial * time * $\mathbf{S}$. & 42 & 1.763 & .042 & & & & \\
\hline
\end{tabular}

Dependent: rectal temp

Means Table

Effect: trial

Dependent: rectal temp

\begin{tabular}{|c|c|c|c|c|}
\hline & Count & Mean & Std. Dev. & Std. Error \\
\hline with & 56 & 37.979 & .844 & .113 \\
\hline without & 56 & 38.011 & .814 & .109 \\
\hline
\end{tabular}

\section{Means Table}

Effect: time

Dependent: rectal temp

\begin{tabular}{l|r|r|r|r|}
\multicolumn{4}{c}{ Count } & \multicolumn{2}{c}{ Mean } & Std. Dev. & \multicolumn{1}{c|}{ Std. Error } \\
\hline & 16 & 37.038 & .498 & .124 \\
\hline 15 & 16 & 37.170 & .487 & .122 \\
\hline 25 & 16 & 37.711 & .484 & .121 \\
\hline 35 & 16 & 38.162 & .516 & .129 \\
45 & 16 & 38.496 & .542 & .135 \\
\hline 10 min post & 16 & 38.781 & .605 & .151 \\
\cline { 2 - 5 } & 16 & 38.608 & .507 & .127 \\
\cline { 2 - 5 } & & & &
\end{tabular}

\begin{tabular}{|c|c|c|c|c|}
\hline \multicolumn{5}{|c|}{$\begin{array}{l}\text { Means Table } \\
\text { Effect: trial " time } \\
\text { Dependent: rectal temp }\end{array}$} \\
\hline with, 0 & 8 & 37.054 & .490 & .173 \\
\hline with, 5 & 8 & 37.172 & .511 & .181 \\
\hline with, 15 & 8 & 37.688 & .511 & .181 \\
\hline with, 25 & 8 & 38.130 & .582 & .206 \\
\hline with, 35 & 8 & 38.489 & .645 & .228 \\
\hline with, 45 & 8 & 38.789 & .718 & .254 \\
\hline with, $10 \mathrm{~min}$ post & 8 & 38.529 & .578 & .204 \\
\hline without, 0 & 8 & 37.021 & .539 & .191 \\
\hline without, 5 & 8 & 37.168 & .498 & .176 \\
\hline without, 15 & 8 & 37.734 & .489 & .173 \\
\hline without, 25 & 8 & 38.194 & .479 & .170 \\
\hline without, 35 & 8 & 38.504 & .462 & .163 \\
\hline without, 45 & 8 & 38.773 & .519 & .184 \\
\hline without, $10 \mathrm{~min}$ post & 8 & 38.686 & .449 & .159 \\
\hline
\end{tabular}




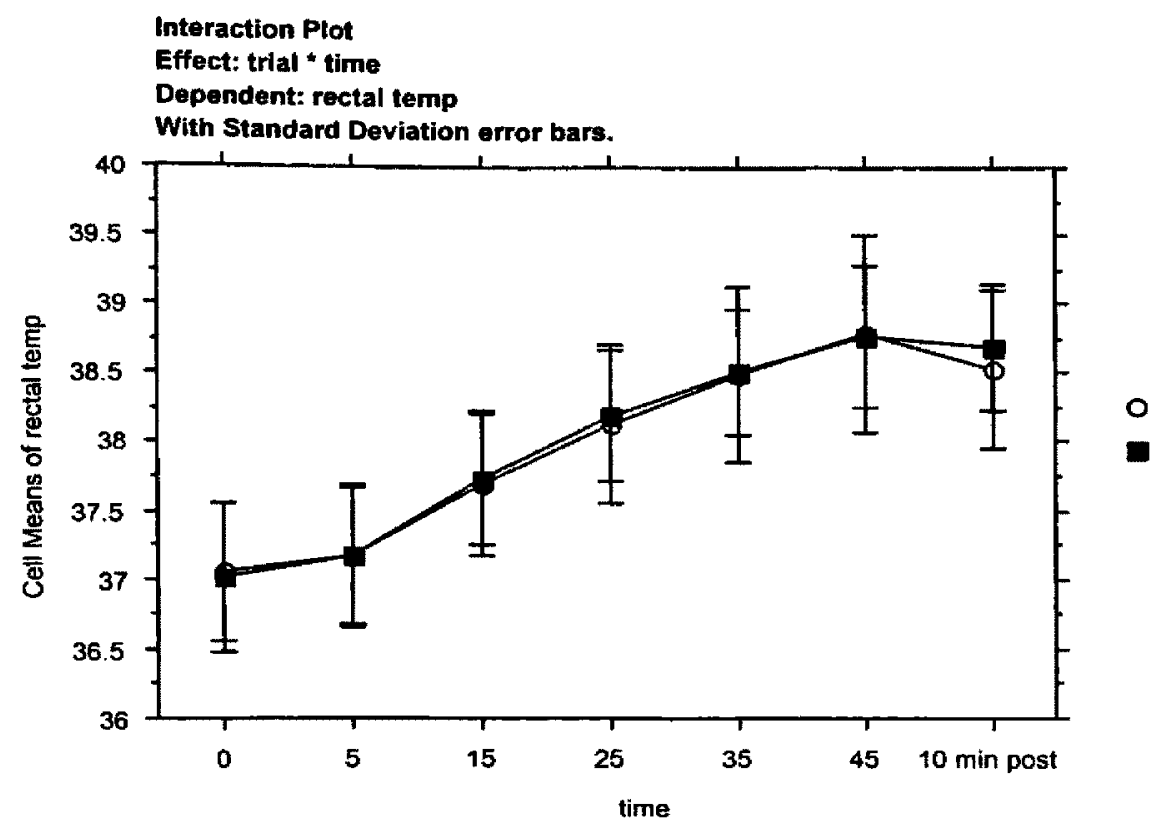

Comparison 1

Effect: Trial * Time
Comparison 2

Effect: Trial * Time

\begin{tabular}{|l|r|}
\hline \multicolumn{2}{|l|}{ With min 0 vs. Without min 0 } \\
\hline df & 1 \\
\hline Sum of squares & .004 \\
\hline Mean square & .004 \\
\hline F-Value & .103 \\
\hline P-Value & .7495 \\
\hline G-G & .4488 \\
\hline H-F & .5285 \\
\hline
\end{tabular}

Comparison 3

Effect: Trial * Time

\begin{tabular}{|l|r|}
\hline \multicolumn{2}{|l|}{ With min 15 vs. Without min 15 } \\
\hline df & 1 \\
\hline Sum of squares & .008 \\
\hline Mean square & .008 \\
\hline F-Value & .195 \\
\hline P-Value & .6609 \\
\hline G-G & .3910 \\
\hline H-F & .4601 \\
\hline
\end{tabular}

\begin{tabular}{|l|r|}
\hline With min 5 vs. Without min 5 \\
\hline df & 1 \\
\hline Sum of squares & $8.100 \mathrm{E}-5$ \\
\hline Mean square & $8.100 \mathrm{E}-5$ \\
\hline F-Value & .002 \\
\hline P-Value & .9652 \\
\hline G-G & .7075 \\
\hline H-F & .8018 \\
\hline
\end{tabular}

Comparison 4

Effect: Trial * Time

\begin{tabular}{|l|r|}
\hline With min 25 vs. Without min 25 \\
\hline df & 1 \\
\hline Sum of squares & .016 \\
\hline Mean square & .016 \\
\hline F-Value & .381 \\
\hline P-Value & .5403 \\
\hline G-G & .3250 \\
\hline H-F & .3795 \\
\hline
\end{tabular}


Comparison 5

Effect: Trial $*$ Time

\begin{tabular}{|l|r|}
\hline With min 35 vs. Without min 35 \\
\hline df & 1 \\
\hline Sum of squares & .001 \\
\hline Mean square & .001 \\
\hline F-Value & .021 \\
\hline P-Value & .8862 \\
\hline G-G & .5727 \\
\hline H-F & .6670 \\
\hline
\end{tabular}

Comparison 7

Effect: Trial ${ }^{*}$ Time

\begin{tabular}{|l|r|}
\hline \multicolumn{2}{|l|}{ With 10 post vs. Without 10 post } \\
\hline df & 1 \\
\hline Sum of squares & .099 \\
\hline Mean square & .099 \\
\hline F-Value & 2.357 \\
\hline P-Value & .1322 \\
\hline G-G & .1325 \\
\hline H-F & .1382 \\
\hline
\end{tabular}

\section{Comparison 9}

Effect: Trial * Time

\begin{tabular}{|l|r|}
\hline With min 0 vs. With $\min 45$ \\
\hline df & 1 \\
\hline Sum of squares & 12.035 \\
\hline Mean square & 12.035 \\
\hline F-Value & 286.755 \\
\hline P-Value & .0001 \\
\hline G-G & .0001 \\
\hline H-F & .0001 \\
\hline
\end{tabular}

Comparison 6

Effect: Trial * Time

\begin{tabular}{|l|r|}
\hline \multicolumn{2}{|l|}{ With $\min 45$ vs. Without $\min 45$} \\
\hline df & 1 \\
\hline Sum of squares & .001 \\
\hline Mean square & .001 \\
\hline F-Value & .025 \\
\hline P-Value & .8747 \\
\hline G-G & .5593 \\
\hline H-F & .6527 \\
\hline
\end{tabular}

Comparison 8

Effect: Trial * Time

\begin{tabular}{|l|r|}
\hline \multicolumn{2}{|l|}{ With min 0 vs. With $\min 25$} \\
\hline df & 1 \\
\hline Sum of squares & 4.634 \\
\hline Mean square & 4.634 \\
\hline F-Value & 110.411 \\
\hline P-Value & .0001 \\
\hline G-G & .0001 \\
\hline H-F & .0001 \\
\hline
\end{tabular}

Comparison 10

Effect: Trial * Time

\begin{tabular}{|l|r|}
\hline With min 45 vs. With 10 post \\
\hline df & 1 \\
\hline Sum of squares & .270 \\
\hline Mean square & .270 \\
\hline F-Value & 6.430 \\
\hline P-Value & .0150 \\
\hline G-G & .0477 \\
\hline H-F & .0400 \\
\hline
\end{tabular}


Comparison 11

Effect: Trial * Time

\begin{tabular}{|l|r|}
\hline \multicolumn{2}{|l|}{ Without min 0 vs. Without min 25 } \\
\hline df & 1 \\
\hline Sum of squares & 5.499 \\
\hline Mean square & 5.499 \\
\hline F-Value & 131.023 \\
\hline P-Value & .0001 \\
\hline G-G & .0001 \\
\hline H-F & .0001 \\
\hline
\end{tabular}

Comparison 12 Effect: Trial * Time

\begin{tabular}{|l|r|}
\hline \multicolumn{2}{|l|}{ Without min 0 vs. Without min 45 } \\
\hline $\mathrm{df}$ & 1 \\
\hline Sum of squares & 12.268 \\
\hline Mean square & 12.268 \\
\hline F-Value & 292.292 \\
\hline P-Value & .0001 \\
\hline G-G & .0001 \\
\hline H-F & .0001 \\
\hline
\end{tabular}

\section{Comparison 13}

Effect: Trial $*$ Time

\begin{tabular}{|l|r|}
\hline \multicolumn{2}{|l|}{$\begin{array}{l}\text { Without min 45 vs. Without } 10 \\
\text { post }\end{array}$} \\
\hline df & 1 \\
\hline Sum of squares & .030 \\
\hline Mean square & .0303 \\
\hline F-Value & .709 \\
\hline P-Value & .4045 \\
\hline G-G & .2599 \\
\hline H-F & .2981 \\
\hline
\end{tabular}




\section{Appendix III}

Manuscript for submission to Research in Sports Medicine

Effects of Peripheral Cooling on Substrate Selection During Exercise

David E. Lankford, Brent C. Ruby, Steven E. Gaskill

The University of Montana

Department of Health and Human Performance

McGill Hall room 109

Missoula, MT 59812

Ph. (406) 243-4211

Fax (406) 243-2117

Email ruby@selway.umt.edu 


\begin{abstract}
Purpose: To examine the effects of peripheral cooling via the rapid thermal exchange (RTX) cooling device (AVAcore Technologies Inc.) on whole body substrate oxidation during exercise at a moderate ambient temperature $\left(28^{\circ} \mathrm{C}\right)$. Methods: Subjects $(\mathrm{N}=16)$ completed two 45 -minute cycle ergometer trials at $90 \%$ of ventilatory threshold (VT) with RTX peripheral cooling and without (CON). Rectal temperature was continuously recorded throughout both trials. $\mathrm{VO}_{2}$ and $\mathrm{VCO}_{2}$ were monitored to compute whole body substrate oxidation. Significance was set at $p<0.05$. Results: Despite no differences in rectal temperature between trials, mean CHO oxidation was lower during RTX (1453 \pm $299 \mathrm{~kJ})$ versus CON $(1546 \pm 291 \mathrm{~kJ})$. Conversely, mean fat oxidation was higher during RTX $(719 \pm 248 \mathrm{~kJ})$ versus CON $(610 \pm 197 \mathrm{~kJ})$. HR and RPE were similar between trials. Conclusion: These data indicate the RTX device promotes a decrease in whole body carbohydrate $(\mathrm{CHO})$ reliance despite no difference in rectal temperature. Supported by AVAcore Technologies, Inc.
\end{abstract}

Key words: Carbohydrate, fat, AVAcore.

Running Head: Effects of Peripheral Cooling on Substrate Selection. 


\section{Introduction}

It has been recognized that a rise in body temperature during submaximal exercise will increase muscle glycogenolysis during exercise $[1,2,3]$. Previous research has shown that an attenuated rise in body temperature either by reducing ambient temperatures $[2,4]$, or by cooling $[5,6]$ will reduce temperature induced increases in glycogen flux and total carbohydrate oxidation.

Heat stress also influences lipid mobilization and oxidation, although the concentration of plasma free fatty acids are unaffected by heat stress [3]. Additionally, it has been shown that intramuscular triacylglycerol utilization [3] and free fatty acid uptake [7] are reduced under conditions of muscular thermal stress. These data may suggest a reduction in free fatty acid release by adipocytes during exercise in the heat [8]. It has also been suggested that elevated muscle temperature decreases phosphorylative efficiency in isolated skeletal muscle mitochondria, increasing the reliance on carbohydrate as the primary substrate [9]. Febbraio [1] suggests that elevated muscle temperature may impair mitochondrial function. Mills et al. [10] observed an increase of lipid peroxides, an indicator of oxidative stress, in the plasma of hyperthermic horses exercising to fatigue, possibly supporting the notion that heat stress may impair metabolic function.

To examine alterations in substrate oxidation in the heat, previous research has utilized the measurement techniques of indirect calorimetry $[4,11]$, rates of glucose disposal (glucose Rd) [11], and muscle glycogen depletion [4,6]. It has been shown that heat stress stimulates an increase in hepatic glucose production (glucose $\mathrm{Ra}$ ) without a concomitant rise in glucose $\mathrm{Rd}$ [11]. Febbraio [1] suggests that an increase in body 
temperature and perceived effort promote a feed-forward effect resulting in increased blood catecholamines which in return increases muscle glycogenonlysis.

Past research has consistently demonstrated increased whole body CHO oxidation from indirect calorimetry during heat stress $[4,11,12]$. Augmented glycogen utilization during heat stress was first reported by Fink et al. [3] while comparing exercise at ambient temperatures of $40^{\circ} \mathrm{C}$ and $9^{\circ} \mathrm{C}$. Fink et al. also noted an increased respiratory exchange ratio and reduced intramuscular triglyceride use. Using water-perfused cuffs to cool one thigh and heat the other during submaximal exercise, Starkie et al. [6] found lower post exercise muscle glycogen levels in the heated leg compared with the cool leg.

Consistent with increased $\mathrm{CHO}$ oxidation, previous studies have consistently demonstrated an elevated blood lactate accumulation during exercise in the heat $[3,4,11,12]$. Hargreaves et al. [11] suggests that increased blood lactate is associated with increased rates of muscle glycogenolysis, since total carbohydrate oxidation is increased while glucose $\mathrm{Rd}$ is unaltered.

Past research on substrate use under conditions of heat stress can be categorized into two parts: 1) those comparing exercise in extremely different ambient temperatures or 2) those comparing exercise using cooling methods resulting in temperatures exceedingly lower than normal ambient working temperatures. Under normal circumstances exercise is most often performed within a relatively narrow temperature range of comfortable temperatures unlike the extreme temperature differences used for most prior research.

Slight to moderate core temperature cooling can be achieved through use of the AVAcore (AVAcore Technologies Inc.) rapid thermal exchange (called RTX) device. 
The technology behind the RTX exploits the fact that under various surfaces of the body are arterio-venous anastomoses and venous plexuses involved in heat exchange from the body to the environment. These special exchange sites are found in high concentrations on the palms of the hands, soles of the feet and on the face. Blood flow is amplified to these areas with the AVAcore RTX device by using negative pressure to enhance heat exchange. The RTX's temperature is controlled via water flow at adjustable temperatures, which cools a metal surface on which the palm of the hand is placed.

The purpose of this study was therefore to evaluate the effect of exercise on substrate utilization at ambient temperatures commonly found in exercise facilities $\left(28^{\circ} \mathrm{C}\right)$. We compared substrate utilization under conditions of slight cooling $\left(22^{\circ} \mathrm{C}\right)$ of one hand using the RTX with negative pressure to a control trial (CON) without cooling. We hypothesized that the RTX cooling device would significantly reduce body temperature during exercise thereby reducing calculated rates of whole body $\mathrm{CHO}$ oxidation.

\section{Methods}

Sixteen recreationally active males participated in the study after completing a University IRB approved informed consent. Exercise Testing

For the initial session subjects completed a graded exercise cycle test using a Monark 824E mechanically braked cycle ergometer (Varberg, Sweden) to determine ventilatory threshold (VT) and peak $\mathrm{VO}_{2}$ work rates. The graded exercise consisted of 1 minute $(\mathrm{min})$ stages starting at 70 -watts and increased 15 -watts for each subsequent stage 
until volitional exhaustion. Cadence was maintained at 70 revolutions per minute. Expired gases were collected using a calibrated metabolic cart (Parvomedics, Inc., Salt Lake City, UT) and analyzed at 15 -second intervals. VT was determined using a combination of the V-slope method, the ventilatory equivalent method and the excess $\mathrm{CO}_{2}$ method [13]. Subject's characteristics are outlined in Table 1.

\section{Trials}

Each subject was asked to refrain from strenuous exercise, caffeine, alcohol, and tobacco for 24-hours prior to each trial. All trials were performed in the morning following a 10-hour fast. Subjects cycled at an intensity equivalent to $90 \%$ of VT work rate for 45 -min. Exercise chamber temperature was controlled at $28^{\circ} \mathrm{C}$ for both trials. Subjects received either $22^{\circ} \mathrm{C}$ cooling (RTX) from the AVAcore hand device (manifold $\mathrm{T}=22^{\circ} \mathrm{C}, \mathrm{P}=635 \mathrm{mmHg}$ ) or no cooling (control $=\mathrm{CON}$ ) using a random cross-over design. Core body temperature was continuously recorded on an Omega data logger using a Mon-a-therm (Mallinkrodt Medical, Inc.) rectal probe inserted to a depth of at least 10 cm. Heart rate was monitored with a telemetry system (Polar, Port Washington, NY) and recorded using a 2-min average every $10-\mathrm{min}$, starting at min 5 . RPE was recorded every 10 -min starting at $\min 5$.

Whole blood samples $(15 \mu \mathrm{l})$ to measure blood lactate were collected from the fingertip at $\min 0,15,25,35$ and 45 . Blood samples were mixed with $100 \mu 1$ chilled perchloric acid and stored at $-30^{\circ} \mathrm{C}$ until subsequent analysis. Blood lactate was analyzed using an enzymatic, spectrophotometric method. All samples were analyzed in duplicate. 
Whole body carbohydrate and fat oxidation were calculated, using the Frayn equation [14], from average steady state $\mathrm{VO}_{2}$ and $\mathrm{VCO}_{2}$ measures collected for the 2-min prior to $\min 5,15,25,35$ and 45 of the trial. Following the completion of each trial, a passive recovery took place for 10-min in which time only rectal temperature was recorded.

\section{Statistics}

$\mathrm{HR}, \mathrm{RPE}$, fat oxidation $\left(\mu \mathrm{mol} \cdot \mathrm{kg}^{-1} \cdot \mathrm{min}^{-1}\right)$ and $\mathrm{CHO}$ oxidation $\left(\mu \mathrm{mol} \cdot \mathrm{kg}^{-1} \cdot \mathrm{min}^{-1}\right)$ were compared across trials using apriori planned comparison for min $5,15,25,35$, and 45. Pre-planned comparisons were used to examine within trials differences in HR, RPE, fat oxidation and CHO oxidation at $\min 5$ vs. 45 . Temperature differences between trials were examined using apriori planned comparisons at $\min 0,45$, and 10-min post exercise. Apriori planned comparisons were also used to determine within trial changes in temperature ( $\min 0$ vs. 45 and $\min 45$ vs. 10-min post). Differences in overall energy expenditure (total $\mathrm{kJ})$, total fat $\mathrm{kJ}$ (fat $\mathrm{kJ})$, and total $\mathrm{CHO} \mathrm{kJ}(\mathrm{CHO} \mathrm{kJ})$, were examined using 2-tailed paired t-tests. Blood lactate was examined using apriori planned comparisons between trials at $\min 15,25,35$, and 45 and within trials across time ( $\min 0$ vs. 45). Statistical significance was set at $p<0.05$. All data are shown as means \pm standard deviation (SD). 


\section{Results}

\section{CHO Utilization}

Within trials both RTX and CON demonstrated significant decreases in CHO oxidation with time from $\min 5$ to 45 (RTX $\Delta \mathrm{CHO}=-6.5 \pm 17.1 \mu \mathrm{mol} \cdot \mathrm{kg}^{-1} \cdot \mathrm{min}^{-1}, \mathrm{p}<$ 0.05 , CON $\left.\triangle \mathrm{CHO}=-22.5 \pm 26.5 \mu \mathrm{mol} \cdot \mathrm{kg}^{-1} \cdot \mathrm{min}^{-1}, \mathrm{p}<0.001\right)$. Between trials CHO oxidation was significantly decreased during RTX compared with CON at min $5,15,25$, and 45 (see Figure 1).

\section{Fat Utilization}

Within trials both RTX and CON demonstrated significant increases in fat oxidation from $\min 5$ to $45\left(\mathrm{RTX} \Delta \mathrm{FAT}=1.5 \pm 2.4 \mu \mathrm{mol} \cdot \mathrm{kg}^{-1} \cdot \mathrm{min}^{-1}, \mathrm{p}<0.001, \mathrm{CON}\right.$ $\left.\Delta \mathrm{FAT}=2.4 \pm 1.7 \mu \mathrm{mol} \cdot \mathrm{kg}^{-1} \cdot \mathrm{min}^{-1}, \mathrm{p}<0.001\right)$. Between trials $\mathrm{RTX}$ cooling resulted in a significant decrease in fat utilization at $\min 5,15,25$ and 45 compared with CON (see Figure 2).

\section{Heart Rate}

Within trials heart rate increased significantly with time between min 0 and 45 for both trials (RTX $\Delta H R=21.6 \pm 7.4, p<0.001, \mathrm{CON} \Delta \mathrm{HR}=18.3 \pm 8.3, \mathrm{p}<0.001)$. Between trials, RTX resulted in a significantly lower heart rate only at min 5 compared to CON $(p<0.01$, see Table 2).

RPE

Within trials there was a significant increased in RPE between min 0 and 45 for both trials $(\mathrm{RTX} \triangle \mathrm{RPE}=2.3 \pm 2.1, \mathrm{p}<0.001, \mathrm{CON} \triangle \mathrm{RPE}=3.2 \pm 2.4, \mathrm{p}<0.001) . \mathrm{RPE}$ 
during RTX cooling was significantly lower at $\min 15(\mathrm{p}<0.05)$ and $35(\mathrm{p}<0.05)$ compared with CON (see Table 2).

\section{Rectal Temperature}

There were no significant differences in rectal temperature between trials (see Figure 3). Both trials resulted in a significant increase in rectal temperature between min 0 and $45\left(\operatorname{RTX} \Delta^{\circ} \mathrm{C}=1.3 \pm 0.6, \mathrm{p}<0.001, \operatorname{CON} \Delta^{\circ} \mathrm{C}=1.4 \pm 0.5, \mathrm{p}<0.001\right)$, and a significant decrease between $\min 45$ and 10 -min post $\left(R T X \Delta^{\circ} \mathrm{C}=-0.2 \pm 0.5, p<0.001\right.$, $\left.\operatorname{CON} \Delta^{\circ} \mathrm{C}=-0.2 \pm 0.6, \mathrm{p}<0.001\right)$.

\section{Blood Lactate}

Both trials resulted in a significant increase in blood lactate $\left(\mathrm{BLa}^{+}\right)$with time between min 5 and $45\left(\mathrm{RTX} \Delta \mathrm{BLa}^{+}=1.1 \pm 1.1 \mathrm{mM}, \mathrm{p}<0.001, \mathrm{CON} \Delta \mathrm{BLa}^{+}=2.1 \pm 2.4\right.$ $\mathrm{mM}, \mathrm{p}<0.001)$. During RTX, $\mathrm{BLa}^{+}$was significantly lower at $\min 35(\mathrm{p}<0.05)$ and 45 $(p<0.001)$ compared with CON (see Table 3$)$.

\section{Energy Expenditure}

Total energy expenditure was not significantly different between trials $(\mathrm{RTX}=2172 \pm 426 \mathrm{~kJ}, \mathrm{CON}=2156 \pm 403 \mathrm{~kJ}, \mathrm{p}=0.31)$. $\mathrm{RTX}$ resulted in both greater total fat utilization than $\operatorname{CON}(719 \pm 248 \mathrm{~kJ}$ vs. $610 \pm 197 \mathrm{~kJ}$ respectively, $\mathrm{p}<0.01)$ and lower total CHO utilization ( $1453 \pm 299 \mathrm{~kJ}$ vs. $1546 \pm 291 \mathrm{~kJ}$ respectively, $\mathrm{p}<0.05)$ than CON (see Table 4).

\section{Discussion}

Previous studies have shown that cooling influences metabolic substrate selection during exercise $[1,2,3,7]$. Febbraio [8] suggests that changes in body temperature greater 
than $0.4^{\circ} \mathrm{C}$ can cause decreased fat and increased carbohydrate metabolism. The present study differed from the results of Febbraio in that RTX hand cooling resulting in decreased $\mathrm{CHO}$ and increased fat utilization despite no significant differences in rectal temperature between trials. During the cooling trial with the AVAcore RTX device, the decreased reliance on $\mathrm{CHO}$ and increased reliance on fat occurred largely at the beginning of exercise $\left(\min 5=5.2 \pm 3.6\right.$ vs. $3.5 \pm 3.2 \mu \mathrm{mol} \cdot \mathrm{kg}^{-1} \cdot \mathrm{min}^{-1}$ for RTX and CON respectively). We cannot explain the physiological mechanism responsible for this early decreased reliance in CHO. Some psychological or other feedback mechanism as a result of the hand on the cool surface of the RTX may have influenced catecholamine response early in the exercise, which was later modulated by the effects of the exercise. We have no evidence for these effects, but the pattern of reduced CHO dependence during early exercise in the RTX trial was seen across subjects.

Hargreaves and colleagues [11] suggest that during heat stress an increased blood lactate may be associated with an increased rate of muscle glycogenolysis, since blood glucose uptake is reduced with a concomitant rise in total carbohydrate oxidation. The present data demonstrates an increase in blood lactate during the last 10-min of exercise in the CON. Considering the difference in CHO oxidation across trials at the end of exercise, these results suggest a possible increase in muscle glycogenolysis during the later portion of CON. However, we are skeptical to conclude that glucose uptake was altered due to an increased heat load during the $\mathrm{CON}$ trial as there were no differences in rectal temperature. The subtle cooling provided by the RTX may have had other effects than cooling core temperature. An additional possibility is that the temperature in the working skeletal muscle was reduced due to increased perfusion of slightly cooled blood, 
while the rectal temperature remained unaffected due to reduced blood flow to the gut during exercise.

At exercise intensities below VT it is common to note an increased reliance on fat oxidation over time. Given the mild temperature environment and the moderate exercise intensity of the present study, it is doubtful that muscle temperature increased to a level that would impair lipid metabolism through oxidative phosphorylation [9]. During the first 15 minutes of exercise the core temperature under both trials was less than $37.6^{\circ} \mathrm{C}$ and peak core temperature averaged near $38.4^{\circ} \mathrm{C}$ at the end of exercise. Why there would be a difference in substrate utilization at the lower temperatures early in exercise and no difference at the moderate core temperature after 45 minutes of exercise cannot be explained by previous research. Our data agree with others that there should be no difference during the later stages of exercise when core temperature values were not different, however the early differences do not appear to be a result of changes in core temperature. Although catecholamines have been shown to alter substrate selection and are increased during heat stress $[2,11,15]$, it is unclear whether variations in epinephrine could explain the observed difference in substrate oxidation since we did not measure catecholamine levels in the present study. CON resulted in a significantly higher RPE at $\min 15$ and 35 , and approached significance at $\min 25(\mathrm{p}=0.09)$ and $45(\mathrm{p}=0.07)$. This may suggest an increase in sympathetic drive, which would stimulate both hepatic glucose production and carbohydrate oxidation [8]. However, increased catecholamines should also cause an increase in HR, and there were no differences in the HR response between trials with the exception of the initial 5 minutes (RTX $131 \pm 17$, CON $134 \pm 17$ ). The decreased HR at min 5, combined with the lower CHO oxidation early in the RTX 
trial possibly suggest that there was some reduction of catecholamines due to the cooling device though this possibility will require further study.

The similar total energy expenditure between trials verifies the similarity in exercise intensity across trials (see Table 4). That there were no differences in core temperature, no differences in energy expenditure yet early differences in HR and substrate utilization suggest some effect of the RTX device that is not linked to core temperature changes in this study. Use of the RTX may suppress muscle glycogenolysis during the early portion of an exercise session with continued small glycogen sparing over the course of the submaximal exercise bout. For long slow distance (low intensity) aerobic exercise sessions, or to enhance recovery between exercise sessions by reducing within session glycogen depletion, the RTX device may provide benefits to athletes if mobile units are developed.

\section{Conclusion}

In summary, the findings of our study suggest that the use of the AVAcore RTX to supply peripheral cooling influences substrate selection during exercise near VT, especially within the initial stages of an exercise session. However, the underlying physiological mechanism(s) for these results are unclear as there were no rectal temperature differences between trials.

Future research should incorporate measures of intramuscular temperature, patterns of muscle glycogen depletion, and substrate kinetics to further evaluate the physiological effects of the RTX device during exercise. 


\section{References}

1. M.A. Febbraio, Exerc. Sport Sci. Rev. 28, 171 (2000).

2. M.A. Febbraio, R.J. Snow, C.G. Stathis, M. Hargreaves and M.F. Carey, Exp. Physiol. $81,685(1996)$

3. W.J. Fink, D.L. Costill and P.J. Van Handel, Eur J. Appl. Physiol. Occup. Physiol. $34,183(1975)$.

4. M.A. Febbraio, R.J. Snow, C.G. Stathis, M. Hargreaves and M.F. Carey, J. Appl. Physiol. 77, 2827 (1994).

5. S. Kozlowski, Z. Brzezinska, B. Kruk, H. Kaciuba-Uscilko, J.E. Greanleaf and K. Nazar, J. Appl. Physiol. 59, 766 (1985).

6. R.L. Starkie, M. Hargreaves, D.L. Lambert, J. Proietto and M.A. Febbraio, Exp. Physiol. 84, 775 (1999).

7. J. Gonzales-Alonso, J.A. Calbet and B. Nielsen, J. Physiol. 520, 477 (1999).

8. M.A. Febbraio, Sports Med. 31, 47 (2001).

9. G.A. Brooks, K.J. Hittleman, J.A. Faulkner and R.E. Beyer, Am. J. Physiol. 220, 1053 (1971).

10. P.C. Mills, N.C. Smith, I. Casas, P. Harris, R.C. Harris and D.J. Marlin, Eur. J. Appl. Physiol. 74, 60 (1996).

11. M. Hargreaves, D. Angus, K. Howlett, N.M. Conus and M. Febbraio, J. Appl. Physiol. 81, 1597 (1996).

12. A.J. Young, M.N. Sawka, L. Levine, B.S. Cadarette and K.B. Pandolf, J. Appl. Physiol. 59, 1929 (1985). 
13. S.E. Gaskill, B.C. Ruby, A.J. Walker, O.A. Sanchez, R.C. Serfass and A.S. Leon, Med. Sci. Sports Exerc. 33, 1841 (2001).

14. K.N. Frayn, J. Appl. Physiol. 55, 628 (1983).

15. M.A. Febbraio, M.F. Carey, R.J. Snow, C.G. Stathis and M. Hargreaves, Am. J. Physiol. 271, R1251 (1996). 
Table 1. Descriptive characteristics of subjects (mean \pm SD).

\section{Subject $(\mathrm{N}=16)$}

$\begin{array}{lc}\text { Age (yr) } & 25.5 \pm 6.0 \\ \text { Height (in) } & 70.4 \pm 2.2 \\ \text { Height (cm) } & 178.9 \pm 5.7 \\ \text { Body Weight (kg) } & 85.7 \pm 21.6 \\ \text { Fat Mass (kg) } & 14.6 \pm 14.4 \\ \text { Fat Free Mass }(\mathrm{kg}) & 71.1 \pm 8.3 \\ \text { PeakVO }\left(\mathrm{L} \cdot \mathrm{min}^{-1}\right) & 3.9 \pm 0.5 \\ \text { PeakVO }\left(\mathrm{mll}^{-1} \cdot \mathrm{kg}^{-1} \cdot \mathrm{min}^{-1}\right) & 48.9 \pm 14.5 \\ \text { VT }\left(\mathrm{L} \cdot \mathrm{min}^{-1}\right) & 2.5 \pm 0.5 \\ \text { VT (ml-kg } & 31.6 \pm 11.3 \\ \text { VT }\left(\% \mathrm{~min}_{2} \text { peak) }\right. & 64.0 \pm 5.4 \%\end{array}$

Peak $\mathrm{VO}_{2}=$ peak oxygen uptake; $\mathrm{VT}=$ ventilatory threshold. 
Table 2. Heart rate and rate of perceived exertion with RTX and CON.

\begin{tabular}{lccccc}
\hline Minute & 5 & 15 & 25 & 35 & 45 \\
\hline HR & & & & & \\
RTX & $131 \pm 17^{*}$ & $141 \pm 18$ & $146 \pm 17$ & $151 \pm 16$ & $153 \pm 16^{\#}$ \\
CON & $135 \pm 17$ & $142 \pm 18$ & $146 \pm 17$ & $150 \pm 16$ & $153 \pm 16^{\#}$ \\
& & & & & \\
RPE & & & & & \\
RTX & $11.5 \pm 1.3$ & $12.4 \pm 1.0^{*}$ & $13.3 \pm 1.2$ & $14.0 \pm 1.8^{*}$ & $14.4 \pm 2.0^{\#}$ \\
CON & $11.7 \pm 1.2$ & $12.9 \pm 1.4$ & $13.7 \pm 1.7$ & $14.5 \pm 1.6$ & $14.8 \pm 2.1^{\#}$ \\
\hline
\end{tabular}

Significant difference between RTX and CON ${ }^{*} p<0.05$.

Significant difference between minute 5 and 45 within trials $\# p<0.05$. 
Table 3. Comparison of Blood Lactate ( $\mathrm{mM})$ between RTX and CON.

\begin{tabular}{llllll}
\hline Minute & 0 & 15 & 25 & 35 & 45 \\
\hline RTX & $2.3 \pm .9$ & $3.5 \pm 1.5$ & $3.8 \pm 1.4$ & $3.9 \pm 1.5^{*}$ & $3.5 \pm 1.3^{* \#}$ \\
CON & $2.4 \pm 1.1$ & $3.8 \pm 1.8$ & $3.8 \pm 1.7$ & $4.5 \pm 2.0$ & $4.5 \pm 2.5^{\#}$ \\
\hline
\end{tabular}

${ }^{*} \mathrm{p}<0.05$ Significant difference between RTX and CON.

$\# p<0.05$ Significant difference between minute 0 and 45 within trials. 
Table 4. Exercise trial data. The intensity of exercise is shown both as a percent of $\mathrm{VO}_{2} \max \left(\% \mathrm{VO}_{2} \max \right)$ and as a percent of $\mathrm{VO}_{2} \mathrm{Vt}(\% \mathrm{VT})$. Total substrate oxidation in kilojoules for the 45 minutes of exercise is shown for carbohydrate (CHO kJ), fat (FAT $\mathrm{kJ})$ and overall (Total $\mathrm{kJ})$.

\begin{tabular}{lcclll}
\hline Trial & $\% \mathrm{VO}_{2} \max$ & $\% \mathrm{VT}$ & $\mathrm{CHO}$ kJ & Fat kJ & Total kJ \\
\hline RTX & $60.8 \pm .07$ & $94.0 \pm .07$ & $1453 \pm 299^{*}$ & $719 \pm 248^{*}$ & $2172 \pm 426$ \\
CON & $59.2 \pm .06$ & $93.1 \pm .06$ & $1546 \pm 291$ & $610 \pm 197$ & $2156 \pm 403$ \\
\hline
\end{tabular}

${ }^{*} \mathrm{p}<0.05$ Significant difference vs. CON. 


\section{Figures Legend}

Figure 1. CHO oxidation of subjects during RTX and CON (Mean \pm SE).

${ }^{*} \mathrm{p}<0.05$ RTX vs. CON.

$\# p<0.05$. vs. min 0 within trials.

Figure 2. Fat oxidation of subjects during RTX and CON (Mean $\pm \mathrm{SE}$ ).

$*_{p}<0.05$ RTX vs. CON.

$\# \mathrm{p}<0.05$. vs. min 0 within trials.

Figure 3. Rectal temperature of subjects during RTX and CON (Mean \pm SE). There were no significant differences between trials.

$\# \mathrm{p}<0.05$ min 0 vs. 45 within trials.

$\dagger \mathrm{p}<0.05 \min 45$ vs. 10 -post within trials. 


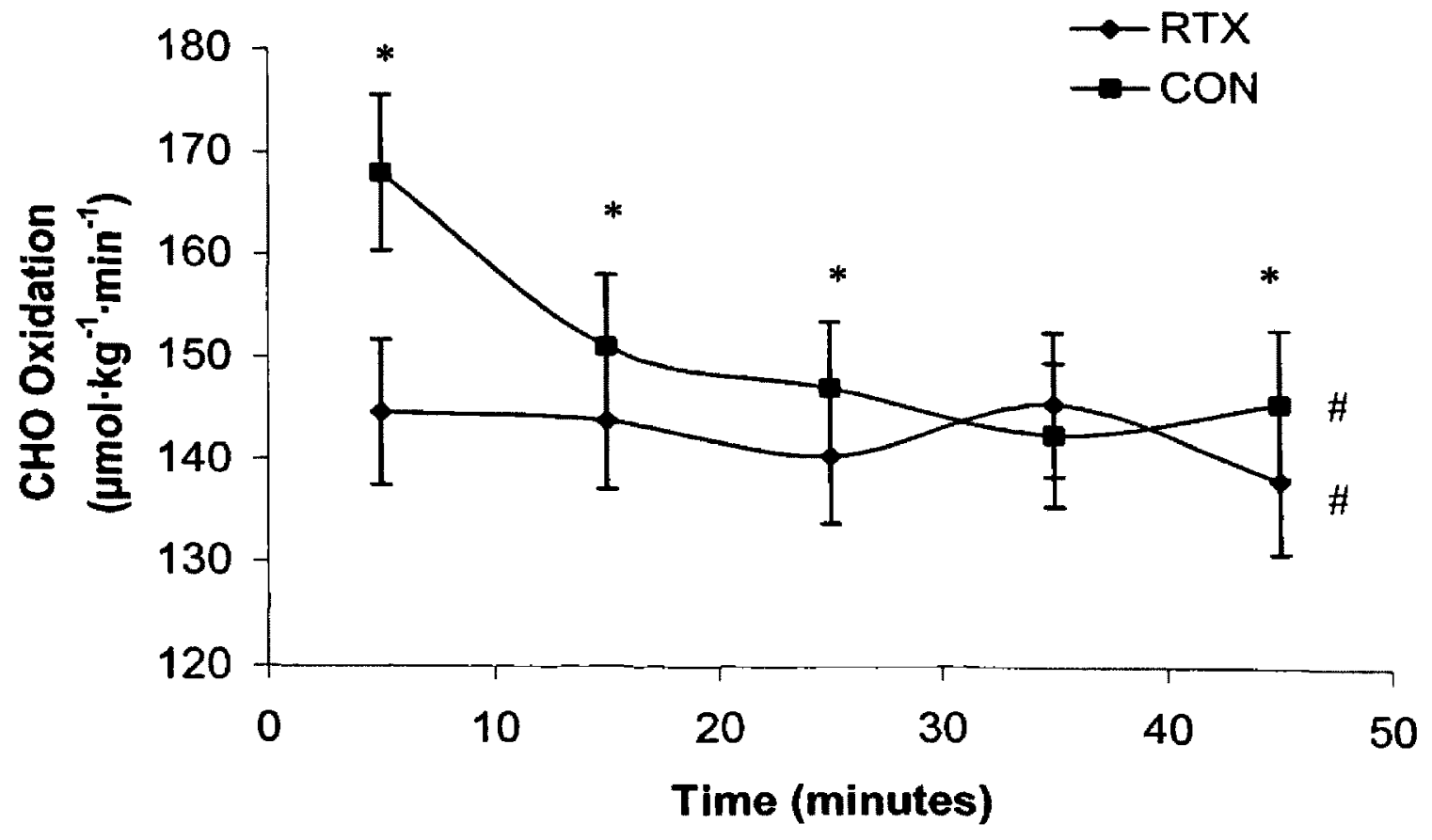




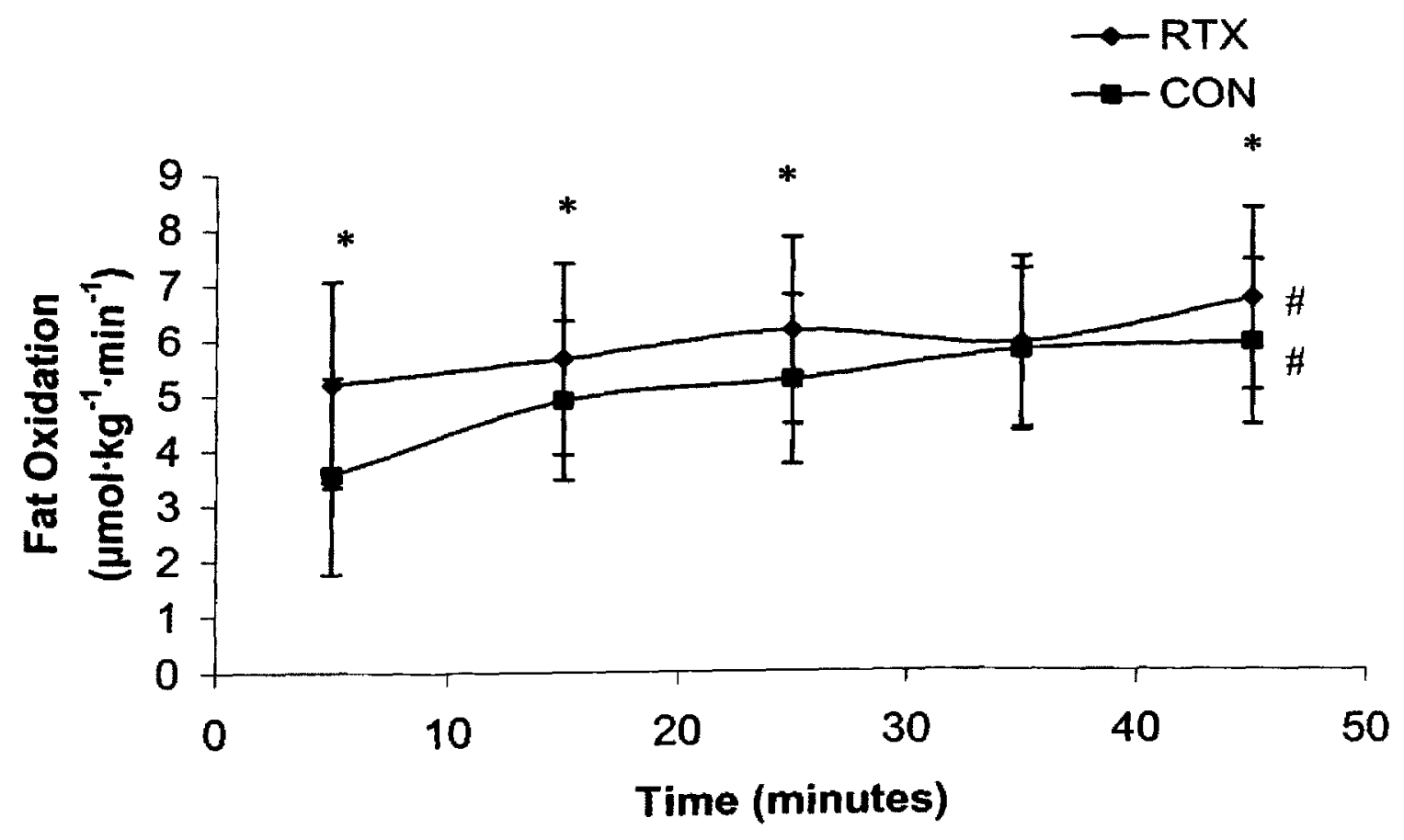


$\rightarrow$ RTX

$\rightarrow$ CON

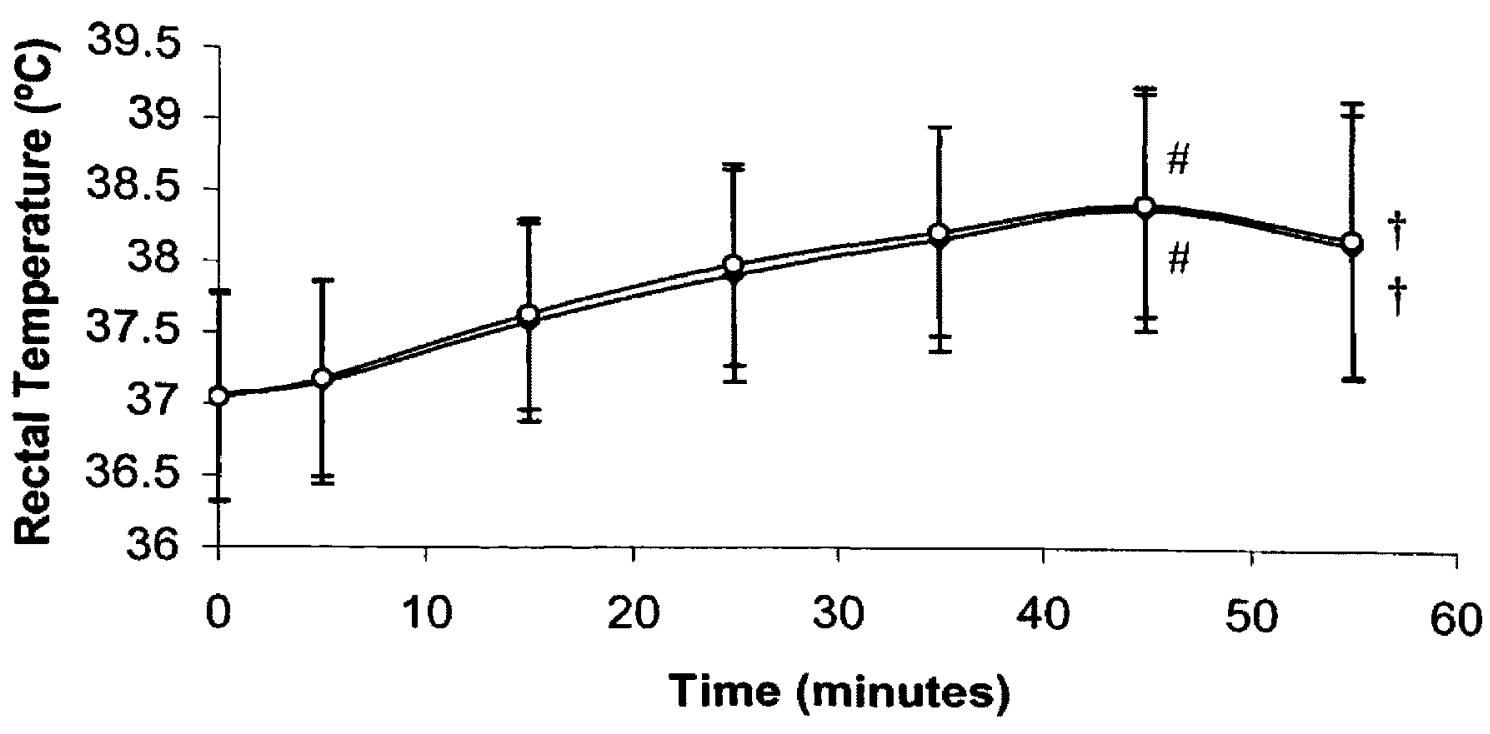

